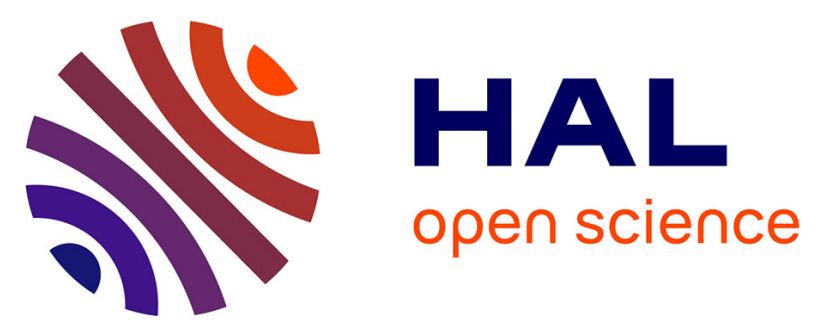

\title{
Mesozoic rifting evolution of SW Gondwana: a poly-phased, subduction- related, extensional history responsible for basin formation along the Argentinean Atlantic margin
}

Juan Pablo Lovecchio, Sébastien Rohais, Philippe Joseph, Néstor Bolatti, Victor Ramos

\section{To cite this version:}

Juan Pablo Lovecchio, Sébastien Rohais, Philippe Joseph, Néstor Bolatti, Victor Ramos. Mesozoic rifting evolution of SW Gondwana: a poly-phased, subduction- related, extensional history responsible for basin formation along the Argentinean Atlantic margin. Earth-Science Reviews, 2020, 203, pp.103138. 10.1016/j.earscirev.2020.103138 . hal-02553358

\section{HAL Id: hal-02553358 \\ https://hal-ifp.archives-ouvertes.fr/hal-02553358}

Submitted on 5 May 2020

HAL is a multi-disciplinary open access archive for the deposit and dissemination of scientific research documents, whether they are published or not. The documents may come from teaching and research institutions in France or abroad, or from public or private research centers.
L'archive ouverte pluridisciplinaire HAL, est destinée au dépôt et à la diffusion de documents scientifiques de niveau recherche, publiés ou non, émanant des établissements d'enseignement et de recherche français ou étrangers, des laboratoires publics ou privés. 
Mesozoic rifting evolution of SW Gondwana: a poly-phased, subductionrelated, extensional history responsible for basin formation along the Argentinean Atlantic margin

Juan Pablo Lovecchio ${ }^{1, *}$ juanlovecchio@yahoo.com.ar, Sébastien Rohais ${ }^{2}$, Philippe Joseph $^{2}$, Néstor D. Bolatti ${ }^{1}$, Víctor A. Ramos ${ }^{3}$

${ }^{1}$ YPF S.A. Exploration. Macacha Güemes 515, 1106, Buenos Aires, Argentina

${ }^{2}$ IFPEN. Direction Georessources. 1-4 avenue de Bois Préau, 92852, Rueil-Malmaison, France

${ }^{3}$ IDEAN. UBA-CONICET. Intendente Güiraldes 2160, 1428. Bi ar Js Aires, Argentina *Corresponding author at: YPF S.A. Exploration. M:-saciıd Güemes 515, 1106, Buenos Aires, Argentina

\section{ABSTRACT}

The opening of the South Atlantı in the Early Cretaceous was the final stage of the complex rifting history of ' $s \mathrm{~V}$; Gondwana. In this contribution we reassess the chronology of Mesozoic basi. forınation in southern South America and Africa and integrate it in the long-terı vreakup history of SW Gondwana. Triassic rifting is characterized by intri cor inental rifting in Africa (Karoo I phase), and retro-arc extension on the SW rargin of Gondwana. In the Early Jurassic, the impingement of the Karoo plume triggered rifting in Eastern Africa, producing the Karoo II basins (and the Colorado and Salado basins on the Argentinean shelf). East Africa rifting ultimately lead the breakup of Eastern from Western Gondwana in the Middle Jurassic. In Patagonia, the Austral, Malvinas and other related basins formed in association with the synextensional emplacement of the Chon Aike magmatic province in the Patagonian retro-arc. In the Late Jurassic the Rocas Verdes back-arc basin opened in southern Patagonia, while oblique rifting in the core of the Late 
Paleozoic Gondwanides orogen produced the Outeniqua and Rawson/Valdés basins. The South Atlantic Rift initiated in the Early Cretaceous associated with present-day E-W extension. Rifting occurred diachronically from south to north, initiating in the previously thinned Rawson/Valdés-Outeniqua segment. A precursor oblique rift system and a larger degree of extension in this segment could explain the lack of Seaward Dipping Reflectors (SDR) south of the Colorado-Cape fracture zones. Rifting and SDR emplacement occurred progressively to the north along different rift segments, producing strongly asymmetric conjugate marrins.

Keywords: Jurassic, Cretaceous, rifting, Gondwana, Ju'tn' Atlantic, Karoo

\section{CONTENT}

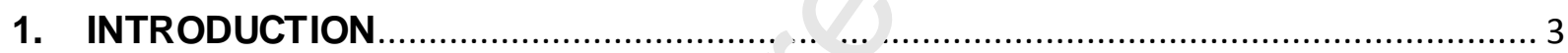

2. GEOLOGICAL FRAMEWORK: PRF.-R F $\mathrm{i}$ 'S CONFIGURATION ........................... 6

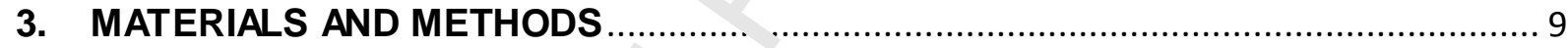

4. MESOZOIC BASINS ACROSS ThE SOUTH ATLANTIC ......................................10

4.1. Mesozoic basins in southe in South America ................................................10

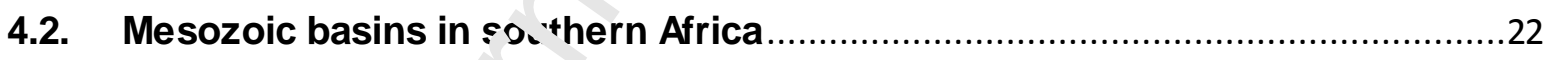

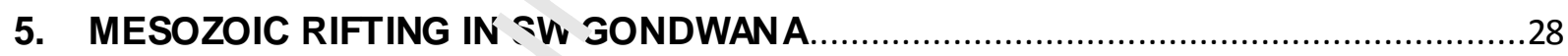

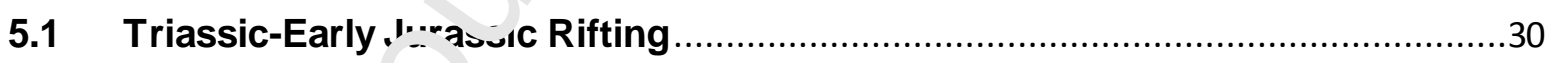

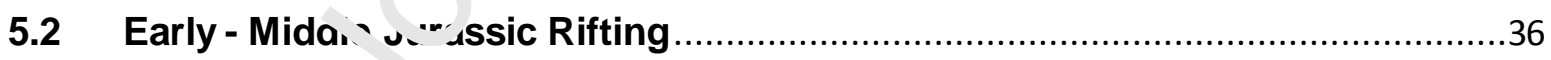

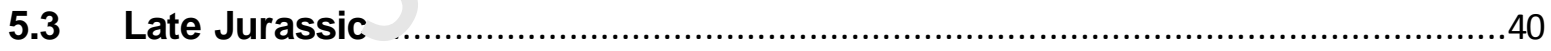

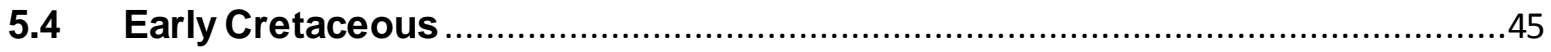

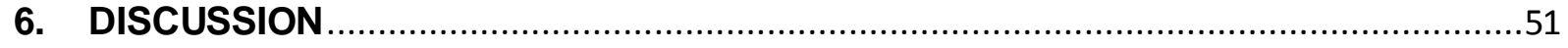

7. CONCLUSIONS

8. ACKNOLEDGEMENTS

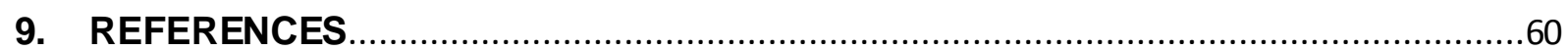




\section{INTRODUCTION}

The process triggering supercontinental breakup has frequently been discussed in the last fifty years. Dewey and Burke (1974) suggested that extension was related to hotspots formed by heat concentration produced by insulation under large continental masses. The distribution of oceans and large igneous provinces (LIP) seemed to support this theory. Buiter and Torsvik (2014) reviewed the role of mantle plumes in continental breakup and note that although there is a spatial relationship, in many margins such as the Central or tho ¿outh Atlantic, rifting had

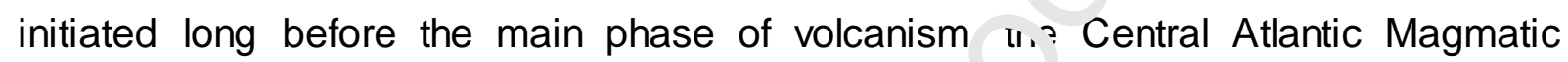
Province (CAMP) and Paraná-Etendeka Large Inn€ی'ıs Province respectively. Rifting and successive breakup of a supercontinent ha'e proved to be a much more complex process, that often occurs in sevt. al phases (Moulin et al., 2010, Fig. 1). Recent studies suggest that landmass instability produced by thermal insulation is insufficient to initiate rifting (Hero, and Lowman, 2011). Subduction-related slab rollback instability is now pres' 'me $\boldsymbol{\top}$ by some authors to play a key role in triggering rifting and successive landri. ?ss dispersal (Bercovici and Long, 2014; dal Zilio et al., 2018). A recent review ni the Pangea breakup by Frizon de Lamotte et al. (2015) propose a combinction of active (induced by an active upwelling of the asthenosphere) and passive rifting (induced by sub-horizontal far-field forces related to subduction) to produce in successive stages the breakup of large continental masses. Active rifting is caused by the impingement of a thermal anomaly (mantle plume), producing doming, volcanism and extension (see Sengör and Burke, 1978). Passive rifting is related to lithospheric far-field forces pulling the lithosphere apart, notably related to subduction zones acting as boundary conditions. 
Supercontinents are intrinsically complex assemblages of cratons and shields bounded by metamorphic orogenic belts (formed during craton amalgamation). The structural grain of these belts introduce heterogeneities which, under extension, can guide fault emplacement and eventually breakup (Buiter and Torsvik, 2014). The supercontinent of Pangea is no exception (Fig. 1), with a complex multi-stage rifting process that lasted more than 100 M.y. This process initiated in the Triassic, with rifting between Laurentia (North America) and Western Gondwana (Fig. 1) and the subsequent opening of the Central Atlantic (Withjack et al., 1999, 2012; Leleu et al., 2016). The emplacement of the CAMP occurred dit $r$ the main phase of rifting (Frizon de Lamotte et al., 2015) and so breakup inc'ild not have been plume-related (McHone, 2000). Triassic basins were not restriste $v$ to the Central Atlantic realm, but other rift basins developed across Gond'Ninz (Uliana et al., 1989; Zerfass et al., 2003) and on the paleo-Pacific conisr, ent margin (Ramos and Kay, 1991; Spikings et al., 2016; Espinoza et al., 2018).

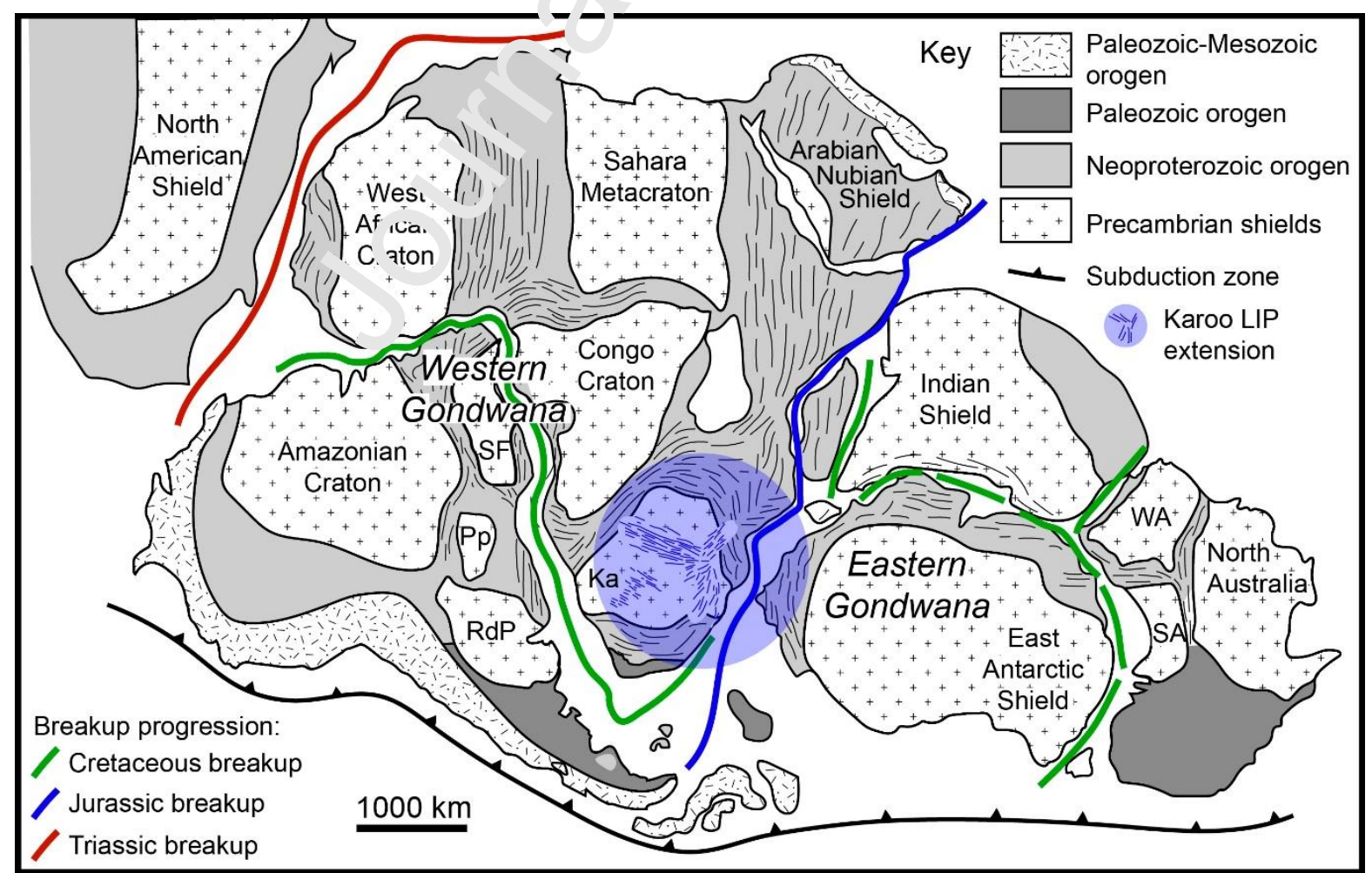


Fig. 1. Progressive Pangea breakup history in a Gondwana view at the end of the Paleozoic after Gray et al. (2008), with main breakup events in the Triassic, Jurassic and Early Cretaceous. Modified from Moulin and Aslanian (2010) and Will and Frimmel (2018). Cratons: RdP: Río de la Plata, Ka: Kalahari, Pp: Paraná-Panema, SF: Sao Francisco, WA: West Australia, SA: South Australia. Note the location of the Karoo LIP relative to the Jurassic breakup of Eastern from Western Gondwana.

On the other hand, the impingement of the Karoo plume on East Africa in the Early Jurassic produced active rifting, characterized by the development of doming, volcanism and eventually caused continental breakup of Western from Eastern Gondwana (Storey et al., 1995; 1997; 2001; Frizon de _amotte et al., 2015). The continent dispersal process continued in the Early Cretaion us with the opening of the South Atlantic Ocean between South America and Aliva and several other oceanic basins produced by the dispersal of the Easte.? Fondwana blocks (note the green breakup emplacements in Fig. 1). As rece itl, , tiscussed by Frizon de Lamotte et al. (2015) and Will and Frimmel (2016', tr 2 south Atlantic is another case of passive rifting, triggered by far-field forces bulling the lithosphere apart. As in the case of the Central Atlantic, this area was a's s uffected by the massive volcanism: the ParanáEtendeka LIP. In this scena"ic the opening seems not to have been triggered by a plume, rather the volcanism ı.ame when rifting was already established (Stica et al., 2014). All in all, the Sirttr Atlantic opening was only the final stage of the long and complex Gondwana w.eakup history, where subduction-related processes played a key role (Storey et al., 1992; Peace et al., 2019).

Those separate Mesozoic rifting events played a key role in basin formation along the South American and African Atlantic margins. Argentinean basins' rifting history was previously addressed by the pioneer integrations of Urien et al. (1981) and notably Uliana et al. (1989), later complemented by the contributions of Ramos (1996), Franzese et al. (2003), and Macdonald et al. (2003). Previous work in the Colorado basin (Fig. 3), was crucial to identify at least three super-imposed rifting 
stages in the Argentinean margin (Lovecchio et al., 2018). By extrapolating previous results from the Colorado and Malvinas basins (Lovecchio et al., 2018, 2019) and by integrating them in a geodynamic framework updated with the geochronological data produced by different authors in the last 30 years, we review in this contribution the chronology of Mesozoic basin formation in southern South America and Africa and integrate those events in the long-term rifting history of SW Gondwana at a supraregional scale. We also present here newly generated paleotectonic models that illustrate the different stages of SW Gondwana Mesozoic riftı' 'y.

\section{GEOLOGICAL FRAMEWORK: PRE-RIFTINGL NNFIGURATION}

Southwestern Gondwana is an assemblare of cratons, metamorphic belts and accreted terranes formed because of $>0$.tir.uous subduction since at least the beginning of the Phanerozoic (Sucre- et al., 2019). In the Neoproterozoic, the Panafrican orogeny welded the Ric te la Plata and African shields through the Dom Feliciano belt (Fig. 2, Basei et $\left.>^{1}<\right\urcorner \div 8$, and references therein).

Since the Cambrian, ana throughout the Paleozoic, subduction from the west produced the accretion of different allochthonous terranes: Pampia, Cuyania, Chilenia, Paracas ('?ıо 1999; 2010). Subduction was active throughout the Paleozoic. The terrane of Patagonia was the last to accrete, in this case from the SW, producing the Gondwanides orogen (Ramos, 2008; Ramos and Aleman, 2000), with a Carboniferous-to-Permian volcanic arc in Northern Patagonia and a Permianto-Early Triassic fold-and-thrust belt (Fig. 2). This fold belt was recognized in South America in the Ventania System (Keidel, 1916; see Pangaro et al., 2016 for further references), that continues in Africa as the Cape fold belt (du Toit, 1927, 1937; Hälbich, 1983) and reaches the Ellsworth-Whitmore Mountains in Antarctica (Curtis, 
2001). In the Mesozoic, under an extensional stress regime, negative inversion affected previously compressive structures (for reference see Glennie and Boegner, 1981, and Williams et al., 1989). This process has been described on the Argentinean shelf in the Colorado basin by Lovecchio et al. (2018). On the African conjugate margin, structures at high angles to the margin orientation, and affecting older series have been described by De Wit and Ransome (1992), and more recently by Paton et al. (2016).

At the end of the Paleozoic, with the accretion nt ? Patagonia from the SW (Ramos, 2008), the amalgamation of Pangea was -01. pleted. But supercontinents, especially those subjected to continuous subductinı, are intrinsically unstable. Soon after the final supercontinent configuration v/a achieved, different instabilities induced the onset of both intracontine $\mathrm{n}_{i}$, and retroarc rifting since the early Mesozoic (Fig. 1). 




Fig. 2: Simplified structu' al scheme of SW Gondwana at the end of the Paleozoic, with a detail of cratons, terranes and metamorphic belts, after Gray et al. (2008); Ramos (2010); Pankhurst et al. (2006); Pángaro and Ramos (2012); and Lovecchio et al. (2018). Main Precambrian mobile belts: Dom Feliciano (DF), Gariep (GB), Namaqua-Natal (Nam-Nat), Mozambique (Moz). Main Paleozoic accreted terranes (in different colours): Pampia (Pam), Cuyania (Cu), Arequipa-Antofalla (AA), Chilenia (Chi). Other Tectonic blocks: ParanáPanema (Pp), Sao Francisco (SF), North Patagonian Massif (NPM), Deseado Massif (DM), Eastern Antarctica (EA), Antarctic Peninsula (AP). Permian-Triassic fold and thrust belt (purple): Ventania system (VS), Prerift of the Colorado basin (CB), Cape Fold Belt (CFB), Ellsworth-Whitmore Mountains (EW). UTM Projection. Undeformed plates, after Ramos (1999, 2008). 


\section{MATERIALS AND METHODS}

After having performed seismic interpretation in the Colorado basin area where three independent Mesozoic rifting events were identified (Lovecchio et al., 2018), in this contribution we correlate and integrate these and other rifting events into a comprehensive scheme of rifting responsible for the formation of the main Mesozoic basins around the South Atlantic realm, with special interest in the evolution of the Argentinean Mesozoic basins. We prepared structural maps, where we compiled published and newly generated data on faullt-bu' inded depocenters, and other structures related to basin formation.

Obtaining geochronological data to constran, the age of the synrift infill is usually challenging. Samples from the synritt series are scarce (i.e. synrift depocenters are usually deeply buried $a_{1} \cdot d$ hydrocarbon exploration wells have commonly been drilled on structura, highs out of the main troughs), or they often consist of red beds (e.g. Barredo it al, 2012; Schmidt et al., 1995) which makes difficult the application of polo. ${ }^{\text {t` }}$ logical or biostratigraphic methods. However, volcanic rocks interbedde:' within the synrift series (e.g. lavas, ash beds), paleontological content a. ad detrital zircon data are often suitable for dating. Chronologic tectonic : har ss summarizing rifting ages for several Mesozoic basins in southern South America and southern Africa were generated. We put together absolute ages from previous publications that constrain synrift infill. Moreover, thermochronological methods allow the interpretation of exhumation events, which can be linked to rifting events in the appropriate tectonic framework. Besides these limits, we present a synthesis of the main rifting episodes observed in the basins of the study area and surroundings. 
Finally, we produced illustrative paleotectonic maps for the main rifting events, we color-coded faults according to the chronology of rifting and propose a model to explain the formation and evolution of the main basins in the study area throughout the Mesozoic finishing with the opening of the South Atlantic.

\section{MESOZOIC BASINS ACROSS THE SOUTH ATLANTIC}

\subsection{Mesozoic basins in southern South America}

South America is bounded to the west by the active margin resulting from the subduction of the oceanic Pacific plate from the west. inciar the continental South American plate (Fig. 3). Subduction has been contin' ou:ly active since the Cambrian and is associated with terrane accretion throughnu: the Paleozoic (Fig. 2; Ramos, 1999). This process is responsible for the large' $y$ c ciented N-S structural fabric, which explains the abundance of N-S striking-st uc ur ss in most of the Mesozoic basins in western South America (Fig. 3). Th心 s,ress regime, related to the subducting slab dynamics, played a key role in struture generation and reactivation under different tectonic regimes. This procesc onerved by Vergani et al. (1995) in the Neuquén basin (Nq in Fig. 3) can be $\epsilon$ : trapolated to other Subandean basins.

Following the pinntir integration presented by Urien et al. (1981) and Uliana et al. (1989), we pres inl in Fig. 3 a map gathering most of the main Mesozoic basins in southern South America (additional references used: Turner, 1979, 1980; Chebli and Spalletti, 1989; Turic et al., 1996; Caminos, 1999; Chebli et al., 2005; and Kozlowski et al., 2011). To assess the continental-scale geodynamic evolution and its impact in basin formation in SW Gondwana, rifting chronology was summarized in charts (Figs. 4 and 6), that constitute a useful tool for grouping rifting events occurring simultaneously at different locations. 
We present hereafter a summary of the main geochronological constraints for the rifting history of the main Mesozoic basins of southern South America in a chronological order. The Cuyo and the Bermejo basins record synrift sedimentation in the Triassic (Fig. 4). These two basins comprehend several depocenters along two axes: the Cuyo basin includes the Río Blanco, Santa Clara, Tupungato, La Esperanza-Divisadero and the General Alvear sub-basins, while the Bermejo basin groups the Ischigualasto, Marayes, Guayagas, Las Salinas and Beazley sub-basins (see Barredo et al., 2012). Vertebrate fossils and rariczenic ages of intruded subvolcanic rocks places rifting in the Early Trias $\leadsto$ in the Bermejo and Middle Triassic in the Cuyo basin (Barredo et al., 201?, Stipanicic, 2001). The Triassic stratigraphy of southern South American basins was reviewed by Jenchen and Rosenfeld (2002) and Zerfass et al. (2004). - hr, se authors highlight inheritance of the basement fabric, with en-echelon tor ucenters produced by NNW trending faults associated with low-to-moderate arıle detachment surfaces. Ramos and Kay (1991) linked the main detachments $f t_{1} c$ listric faults to the hanging-wall suture between Pampia and Cuyania, two i: rrarıes accreted to the SW margin of Gondwana in the Early Paleozoic (Fig. 2)

To the south, 'he Neuquén basin displays two rifting events (Legarreta and Uliana, 1996; Vergani et al., 1995 and references therein). A series of N-S directed isolated half-grabens restricted to the western border of the basin are filled with Late Triassic volcanic rocks and continental sediments of the Precuyano cycle (Carbone et al., 2011; D'Elia et al., 2015). Towards the basin center and east, depocenters change orientation to SE-NW and become younger (Liassic), with active rifting between the Hettangian and the Pliensbachian. This change has been interpreted as a product of basement inheritance permitting transtension (Becchis et al., 2014). 
Outer depocenters are filled with lacustrine successions while depocenters towards the basin center and west are flooded by the paleo-Pacific (Los Molles Fm, see Veiga et al., 2013). A clastic deltaic wedge progrades into that sea during the postrift (Lajas Fm and equivalents). Paleontological and detrital zircon content is abundant in this succession and was used by Naipauer et al. (2018) to calibrate the evolution.

Further south, in the North Patagonian Massif, two retroarc extensional basins develop in the Early Jurassic: the Cañadón Asfalto basin hosts continental successions interbedded with volcanic rocks of Early lıra-sic age (Cúneo et al., 2013; Fígari et al., 2015); and the Chubut basin tow'ari's the west, with development of the marine systems of the Toarcian Osta Arena $F_{1}$ ? (Suárez and Márquez, 2007).

In the San Jorge Gulf basin, Fitzgerald e al. (1990) identified three rifting stages. A first rifting event poorly constrai'€: ' ', oth in age and areal distribution, and was assigned to the Triassic-Mid I ur ussic by extrapolation from deposits in the Deseado Massif (to the south). The ${ }^{\circ}$ deposits are difficult to distinguish from the Mid Jurassic Volcano-Sedimentary C、r.ıplex (Clavijo, 1986), part of the Chon Aike Magmatic Province (Kay st al., 1989; Pankhurst et al., 2000). In the Early Cretaceous, the Neocomicn rifting stage is responsible for the development of halfgrabens, mostly unair continental conditions (Fígari et al., 1997). To the west, several NW-striking depocenters developed in the Rio Mayo embayment (lannizzotto et al., 2004) and were filled with marine series rich in paleontological content (Olivero, 1987; Olivero and Aguirre-Urreta, 2002). Finally, a third rifting stage in the Late Cretaceous is recorded by E-W trending faults on the eastern part of the basin. These faults either reactivate previous normal faults (basement-rooted) or detach within the sedimentary cover (Fitzgerald et al., 1990). 
Offshore Patagonia, the San Julián basin rifting chronology is yet poorly constrained, and its evolution is interpreted to be similar to the Deseado Massif basins (Homovc and Constantini, 2001). However these sequences were not reached by hydrocarbon exploration wells in the San Julián basin (Micucci et al., 2011). 


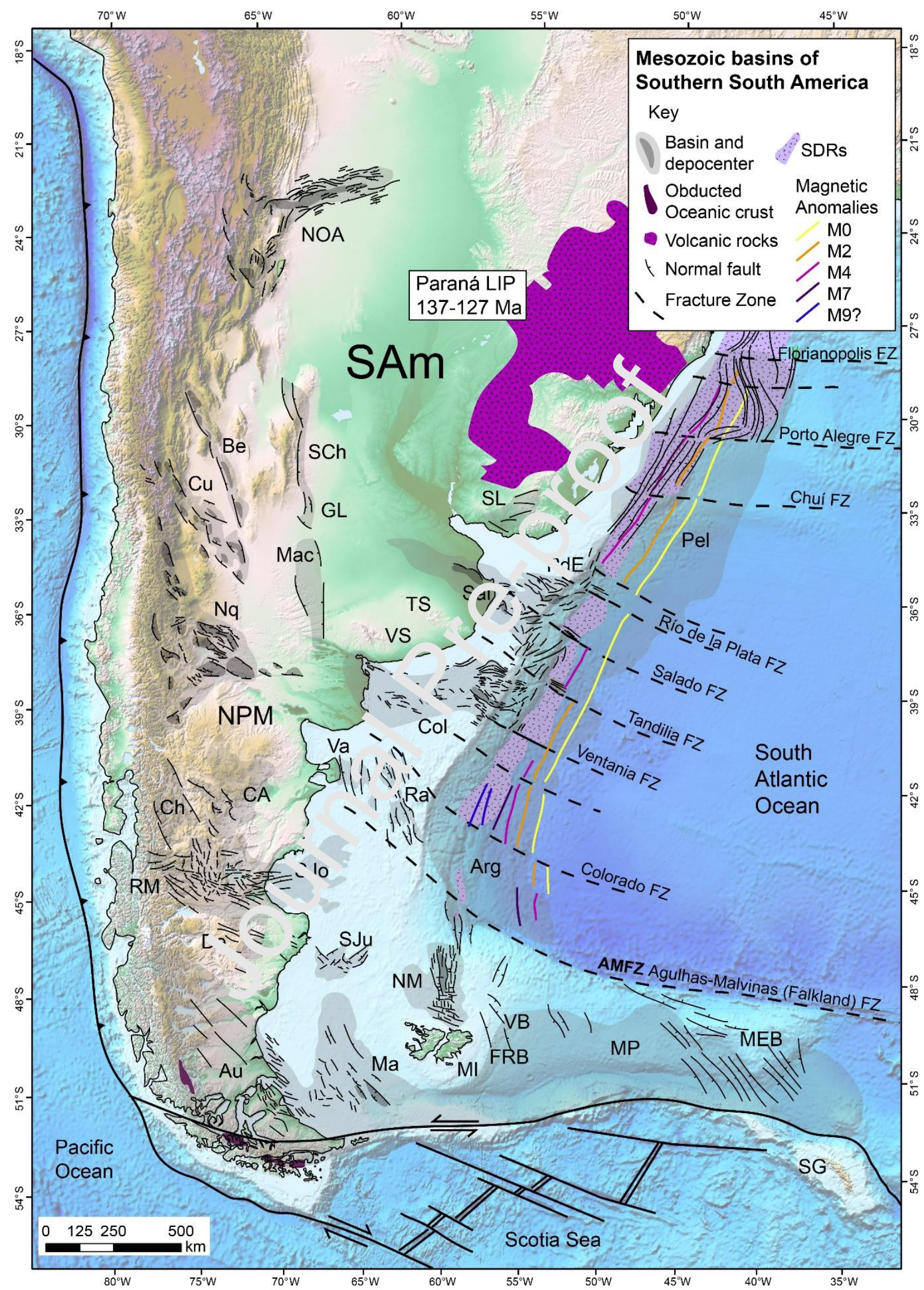

Fig. 3: Map of the main Mesozoic basins of SE South America (SAm). NOA: Northwest Argentina Cretaceous basin, SCh: Sierras Chicas, GL: General Levalle, Mac: Macachín, Be: Bermejo, Cu: Cuyo basin, Nq: Neuquén, NPM: North Patagonian Massif, CA: Cañadón 
Asfalto, Ch: Liassic Chubut basin, RM: Río Mayo, SJo: San Jorge Gulf basin, De: Deseado Massif basin, Au: Austral/Magallanes basin, Ma: Malvinas basin, NM: North Malvinas (North Falkland), Arg: Argentina basin, SJu: San Julián, Va: Valdés, Ra: Rawson, Col: Colorado, Sal: Salado, PdE: Punta del Este basin, SL: Santa Lucía, Pel: Pelotas. Other features: Ml: Malvinas (Falkland) islands, VB: Volunteer basin, FRB: Fitz Roy basin, MP: Malvinas (Falkland) Plateau, MEB: Maurice Ewing Bank, SG: South Georgia, VS: Ventania system, TS: Tandilia system. FZ: Fracture Zone. Faults and depocenters after Uliana et al. (1995, 1989); Veroslavsky (1999); Franke et al. (2007); Micucci et al. (2011); Starck (2011); Becker et al. (2012); Bechis et al. (2014); Stica et al. (2014); Figari et al. (2015); Folguera and lanizzotto (2004), Lohr and Underhill (2015); Gianni et al. (2015), Lovecchio et al. (2018, 2019) and Rodriguez Raising et al. (2019). Background topography from Etopo 1 (Amante \& Eakins, 2009).

The Deseado Massif was affected by the profus : v'canism of the Chon Aike Magmatic Province in the Jurassic (Pankhurst et a . 2 )00). However, remnants of two older sedimentary basins crop out among the volcanic cover: the Permian La Golondrina and the Triassic El Tranquilo seriss (thaı we gather here in the Deseado Massif basin). Various tectonic settinns rave been assigned for these extensional basins. Bellosi and Jalfin (1989) su, poort an intra-arc basin interpretation, while Ramos and Palma (1996) inte, rre re an intracratonic setting. An Early-to-Middle Jurassic rifting event is confi me $d$ across the Deseado Massif area, with volcanic rocks and continental dêrns.'s rich in volcaniclastic content (Gust et al., 1985; Figueiredo et al., 1996'.

Further south, the Austral (Magallanes) and the Malvinas basins record a main phase of rifting in the Early-to-Middle Jurassic, with half-grabens largely oriented NNW (Fig. 3). The presence of a Triassic synrift below the Malvinas basin was proposed by Uliana et al. (1989) and recently confirmed by Lovecchio et al. (2019). In the Tierra del Fuego island, the main synrift stage for the Austral (Magallanes) basin was dated Early Jurassic in an exploration well (Pankhurst et al., 2000). This age is consistent with the Early Jurassic ages for NW-striking igneous dykes in the Malvinas (Falkland) islands (Musset and Taylor, 2004; Stone et al., 2008) and 
thermochronological data interpreted as rift-shoulder uplift at this time (Thomson et al., 2002). The central graben of the Malvinas basin remains undrilled, however recent U-Pb zircon geochronology from an ignimbrite layer at the top of Serie Tobífera (synrift) yielded a Mid Jurassic age (Lovecchio et al., 2019). A new pulse of extension in the Late Jurassic produced retroarc rift basins (filled with the bimodal volcanism of the El Quemado complex, Pankhurst et al., 2000) and the opening of the Rocas Verdes marginal basin towards the west. Oceanic crust accretion is evidenced by the presence of ophiolite complexes (Fig. 2. L ? lziel et al., 1974; Stern, 1979; Stern et al., 1992; Alabaster and Storey, 19r,u, Miukasa and Dalziel, 1996). Reader is referred to the recent reviews publishaci by Calderón et al. (2013) and Malkowski et al. (2015).

To the east, in the North Malvira: (North Falkland) basin (Fig. 3), two intersecting rift systems are observe. ('srandsen et al., 1999). The Neocomian, N-S striking faults forming the northern hranch, intersect the NW-striking faults forming the older southern rift system Th. 0 southern rift system remains underexplored. A Late Jurassic rifting age wis assigned by Lohr and Underhill (2015). However, an Early to Middle Jurassic. ay ${ }^{\circ}$ seems more consistent with regional data, as suggested by Ramos et al. (201?) ine presence of two transecting rift basins has been used to support a rotation of the Malvinas (Falkland) microplate during the Jurassic (sensu Marshall, 1994, Adie, 1952). More recently, this observation has been reinterpreted as a record of the change in the orientation of the stress field between the Jurassic and the Early Cretaceous (Brandsen et al., 1999; Lohr and Underhill, 2015; Ramos et al., 2017).

The Malvinas (Falkland) Plateau is a projection to the east of the Argentinean continental shelf that extends between the Malvinas (Falkland) Islands and the 
Maurice Ewing Bank (Ewing et al., 1971; Chemale et al., 2018). The plateau limits to the south with the Scotia oceanic plate (via a transpressive margin) and is bounded to the north by the Agulhas-Malvinas (Falkland) Fracture Zone (AMFZ). The geology of the Malvinas (Falkland) Plateau is poorly constrained due to the lack of public seismic data. Biddle et al. (1996) published a map with the main interpreted faults and suggest a Jurassic rifting stage. Marine sedimentation since at least the Mid-toLate Jurassic boundary is recorded in DSDP-511 well on the Maurice Ewing Bank (Price and Gröcke, 2002). Barker (1999) and recently S Snhı nschal and Jokat (2019) proved the presence of oceanic crust under the Jai?au, although other authors suggest highly-extended continental crust (Chemcle et al., 2018; Kimbell and Richards, 2008). Fraticelli et al. (2016) mertic.' the development of two main sedimentary troughs east from the island 3 : hs, Fitz Roy and Volunteer basins (Fig. 3).

North of the AMFZ develops the Southern segment of the South Atlantic Ocean, that extends between the .MAFZ and the Río Grande FZ north of the Pelotas basin (Moulin et al., 2010). This segment is characterized by the overall presence of seaward dipping reflector- (SDRs) on the continent-ocean transition (COT, also referred to as transi: inial domain as in Blaich et al., 2011). SDRs are volcanic wedges with interbedded continental sediments deposited in subaerial environments, emplaced during breakup on both conjugate margins (Hinz, 1981). SDR development characterizes volcanic or magma-rich passive margins such as the Southern South Atlantic. A general review of the Argentinean volcanic margin was presented by Hinz et al. (1999) and Franke et al. (2007; 2010).

The Argentinean shelf is one of the widest platforms in the world. It extends for up to $500 \mathrm{~km}$ east from the coastline and is characterized by the presence of several 
sedimentary basins perched on continental crust, notably San Julián (already discussed), and the Rawson/Valdés, Colorado and Salado/Punta del Este basins (Fig. 3). The Rawson/Valdés basins are two rift basins oriented NNW composed of several half-grabens formed mainly by west-dipping faults. The main depocenters remain undrilled. Otis and Schneidermann (2000) inferred a Mid-Jurassic age for the rifting, while Continanzia et al. (2011) suggest a Late Jurassic-Neocomian age. No absolute ages are available to precisely constrain rifting chronology in the Rawson/Valdés basins.

Further north, the Colorado and Salado/Pu'ila ael Este basins display a general E-W to NW strike at high angles with tho । NE-oriented COT (the area with development of SDRs in Fig. 3). Several hypothe as were proposed to explain this obliquity through: aulacogenic origin (Yriç oy •n 1975; Introcaso and Ramos, 1984), transtensional origin associated wil. l.W-SE dextral shear systems (Keeley and Light, 1993; Tankard et al., 1995; r. anke et al., 2006), structural inheritance (Urien et al., 1995; Gebhard, 2005; Drmir.'sez et al., 2011), and two superimposed rifting stages (Franzese et al., 20C 3: Gerster et al., 2011; Pángaro and Ramos, 2012; Autin et al., 2013; Koopmann eı al, 2014). Recently Lovecchio et al. (2018) interpreted the

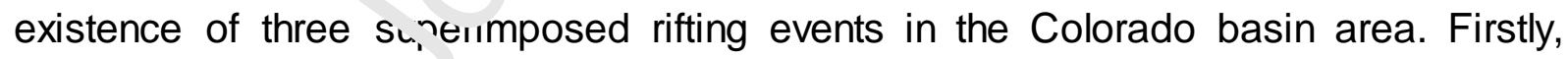
Late Paleozoic thrusts of the Ventania/Cape foldbelt were extensionally reactivated in the Late Triassic-Early Jurassic. These faults were then intersected by Early-to-Mid Jurassic normal faults forming the main depocenters of the Colorado and Salado basins. Finally, in the Early Cretaceous, extension associated with the opening of the South Atlantic generated normal faults in the outermost $100-\mathrm{km}$ strip of continental crust, and characterized by normal faults dipping inboard, as the surfaces limiting SDR wedges. Observations in the Colorado basin were extrapolated to the Salado 
and Punta del Este basins, which are two depocenters separated by the Martín García High and form part of the same rift system (see Raggio et al., 2011 and references therein).

The Salado/Punta del Este and the Santa Lucía basins (located onshore Uruguay) developed on the Rio de la Plata Craton. The Santa Lucía basin has been interpreted as a pull-apart basin, initiated in the Late Jurassic (Veroslavsky, 1999), but the lack of absolute ages impedes confirmation of this interpretation.

The Pelotas basin spans offshore Uruguay and snithurn Brazil (Fig. 3). Rifting in this basin is intimately related to the South Atlar.uc opening (Abreu, 1998), with faults oriented largely parallelly to the COT and dinuing inboard, similarly to the Early Cretaceous faults in the Colorado-Salado segrne, * (Lovecchio et al., 2018). Rifting chronology was constrained by Stica et al $\left(n^{-1} 4\right)$ between a maximum age given by the basalts of the Paraná-Etendeka IP (137-127 Ma, Fig. 3) in the Pelotas basin's prerift and the magnetic anomalie: on SDRs and oceanic crust (Rabinowitz and LaBreque, 1979; Moulin et al., $2 n 1 \%$.

The southernmost At: ntic segments is characterized by an absence of SDRs (Franke et al., 2007; Ber.kr 2 st al., 2010) and the development of a very deep basin, known as the Argentı.? vasin (Fig. 3, Ludwig et al., 1968).

Onshore in central Argentina, a N-S directed branch of Early Cretaceous rift basins is present along the western margin of the Rio de la Plata craton (Fig. 3). From south to north, the Macachín basin (undrilled and only known from gravimetric and refraction seismic data, de Elorriaga, 2010; Kostadinoff and Llambías, 2002) displays a strong NNW direction. Immediately north, the General Levalle basin (Webster et al., 2004) is bounded by a N-S directed high-angle master fault to the west associated with reactivated basement structures. The Sierras Chicas basin in 
Córdoba is formed of different depocenters along the Córdoba ranges. Similarly, to the General Levalle basin, is formed by the extensional reactivation of an eastdipping basement fault. The Sierras Chicas basin was then inverted in the Miocene with the Andean orogeny exposing its whole stratigraphy, characterized by red beds typical of continental settings (Schmidt et al., 1995). Volcanic and subvolcanic rocks interbedded in the synrift succession yield Early Cretaceous ages (Lagorio et al., 2016).

In northern Argentina, the Northwestern Argentina Cretaceous basin also known as the Salta basin (NOA in Fig. 3 and 4) is inrmed of three depocenters: Metán-Alemanía and Tres Cruces depocenters form ? N-S directed branch, while the Lomas de Olmedo depocenter is oriented E-W/ linr general reference see Starck, 2011, and references therein). Synrift is $c)$ in sed of red beds interbedded volcanic rocks. Galliski and Viramonte (198`) eport Early Cretaceous ages for the synrift Pirgua Group. 


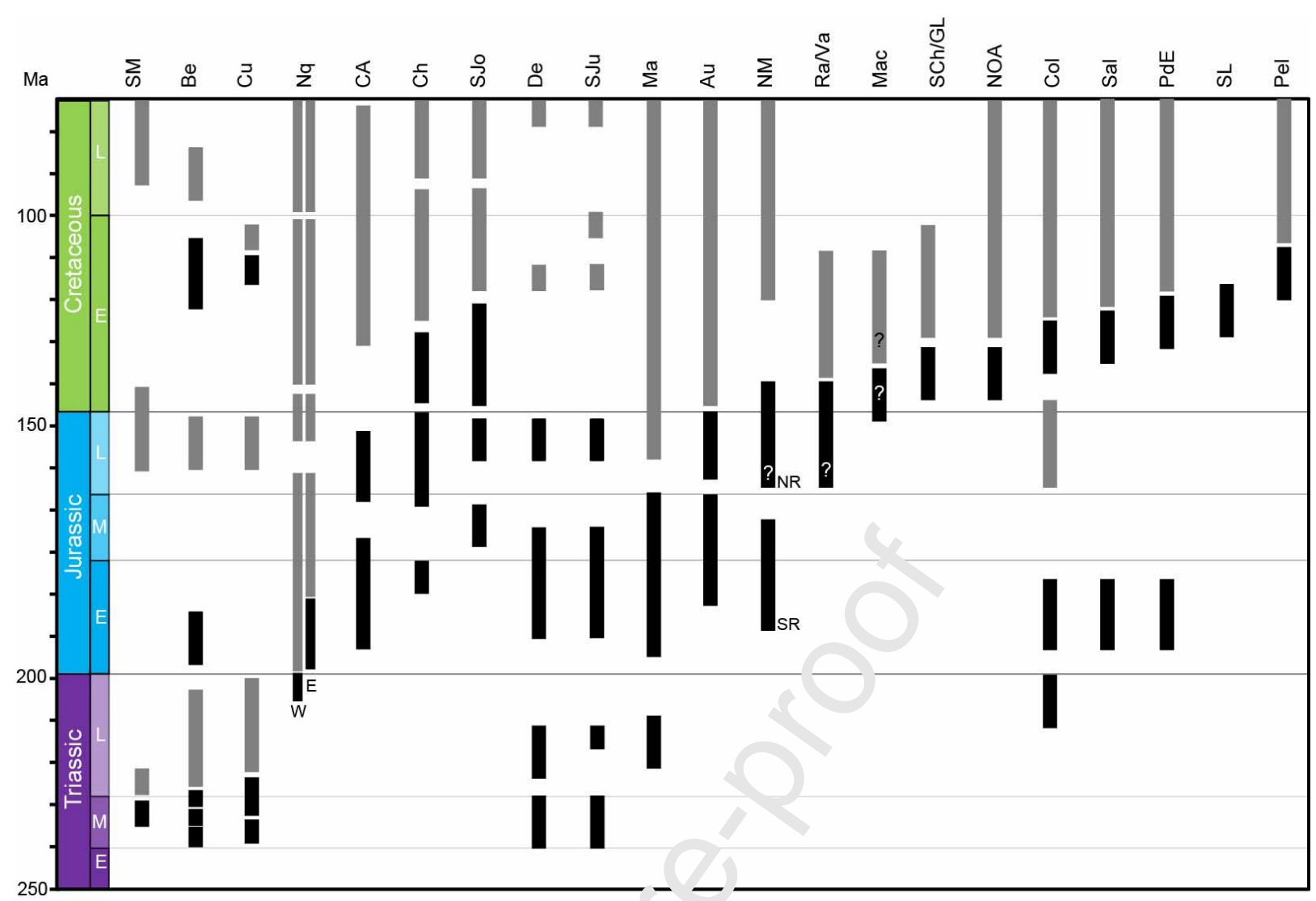

Fig. 4: Rifting chronology chart for the $m=$ in i lesozoic basins of SE South America. Black bars represent active rifting, while grey nar, represent sag or other tectonic scenarios (e.g. drift, foreland). Santa María (SM), Bermejc (Be), and Cuyo basin (Cu) after Kokogian and Mancilla (1989); Zerfass et al. (2004; Barredo et al. (2012) and Colombi et al. (2015). Neuquén basin (Nq) after D'Elia et al '’J15), references therein and authors' interpretation. Cañadón Asfalto (CA) after Cúner, at $:-$. . (2013) and Figari et al. (2015). Chubut Liassic basin after Suárez and Márquez (200i; and references therein, San Jorge Gulf basin (SJo) after Fitzgerald et al. (1990), and la. 'nizzotto et al. (2004). Deseado (De) and San Julián (SJu) basins after Figueiredo et al. '1996). Austral/Magallanes (Au) includes the Late Jurassic Rocas Verdes basin, agrs フtur Pankhurst et al. (2000) and Calderón et al. (2013). Malvinas (Ma) after Galeazzi '19:18) and Lovecchio et al. (2019); North Malvinas (North Falkland) basin after Ramos et c'. (2017); and Lohr and Underhill (2015). Rawson/Valdés basin (Ra/Va) after Continanžıd et al. (2011). Macachín basin (Mac) is undrilled, thus rifting age is poorly constrained. Sierras Chicas and General Levalle basins in Córdoba (SCh/GL) after Lagorio et al. (2016); Schmidt et al. (1995); and Webster et al. (2004). Northwestern Argentina Cretaceous basin (NOA) after Starck (2011) and references therein, age after Galliski and Viramonte (1988). Colorado (Col), Salado (Sal), and Punta del Este (PdE) basins after Lovecchio et al. (2018); Gerster et al. (2011); and Loegering et al. (2013). Santa Lucía basin (SL) after Veroslavsky, (1999). Pelotas (Pel) after Stica et al. (2014) and references therein. 


\subsection{Mesozoic basins in southern Africa}

Although the African basins are not the focus of this study, we summarize their rifting chronology to better illustrate the regional framework in the study of the South American basins.

The collision of Patagonia against the SW margin of Gondwana in the Late Paleozoic produced the Ventania-Cape fold belt and changed the subsidence regime of the neighboring Main Karoo basin of South Africa from intracratonic sag to a foreland setting (Fig. 5, see Veevers et al., 1994; Catuneanu et al., 2005; Miller et al, 2016; Linol and de Wit, 2016). 'Karoo' is a term 'IS used for a large number of extensional basins that developed across Afrira since the Late Carboniferous regardless of the tectonic regime (see the dissus-ion of Guillocheau et al., 2018). These basins record continental deposits I, , $^{\circ}$ sedded with volcanic rocks and lack datable marine fossils. Thus the unrr nostratigraphic framework for these basins remains poorly understood. Frizor, de Lamotte et al. (2015) suggest a two-step scenario, by splitting all the Karo: Jasins in two groups. The first group of Karoo basins (Karoo I) gathers all the Late Carboniferous to Triassic poly-phased depocenters, overall NF- L: $r$ rding; and the Karoo II basins the Jurassic depocenters interpreted to be res ${ }^{+}$eu to extension associated with impingement of the Karoo plume (Bouvet hotspot) and breakup of East Africa from Madagascar and East Antarctica. In this study, to characterize the chronology of the Karoo rifting, we follow the rationale of Frizon de Lamotte et al. (2015) and complement it with the work of Nairn et al. (1991), Smith et al. (1993), Zerfass et al. (2005), Mahanjane (2012), Mueller and Jokat (2017), Guillocheau et al. (2018), and the recent reviews for the East Africa region by Macgregor (2017) and Davison and Steel (2018). 
We present in Fig. 5 a map of the Mesozoic basins in southern Africa. Onshore, besides the Main Karoo Basin (MKB) the other Karoo depocenters are distributed along two axes oriented ENE: 1) the Waterberg-Zambezi axis (Karoo I sensu Frizon De Lamotte et al., 2015); and 2) the Kalahari- Botswana-Limpopo axis (Karoo II). In East Africa, a group of N-S oriented grabens are observed, but they are consequence of two different origins: 1) the Lebombo monocline (Klausen, 2009) and its eastern extension in the Zululand basin (Broad et al., 2012), of Early Jurassic age (Karoo II); and 2) a group of grabens to the east of Early Cstaceous age in the area of Beira (Mozambique, see Senkans et al., 2019).

The southeast coast of Africa is an abrupt $m_{\mathrm{c}}$ rgin largely characterized by the dextral movement of Africa along the AMFZ. hivever, the synrift of the Durban basin (Fig. 5) was drilled offshore and po 0 ir ed Late Jurassic to Late Valanginian ages that were correlated to the rec $b f$ ds described in the Zululand basin by Visser (1998).

In southern South Africa, extensional reactivation of the Cape fold belt throughout the Mesozoic ha- beun described by de Wit and Ransome (1992); Paton (2006) and Paton et al. (? 16). These reactivations are interpreted to have taken place intermittently 4 in $r_{1}, y$ the different extensional events experienced by Africa in the Mesozoic, but so far, they are poorly constrained in age as many other Karoo basins. 


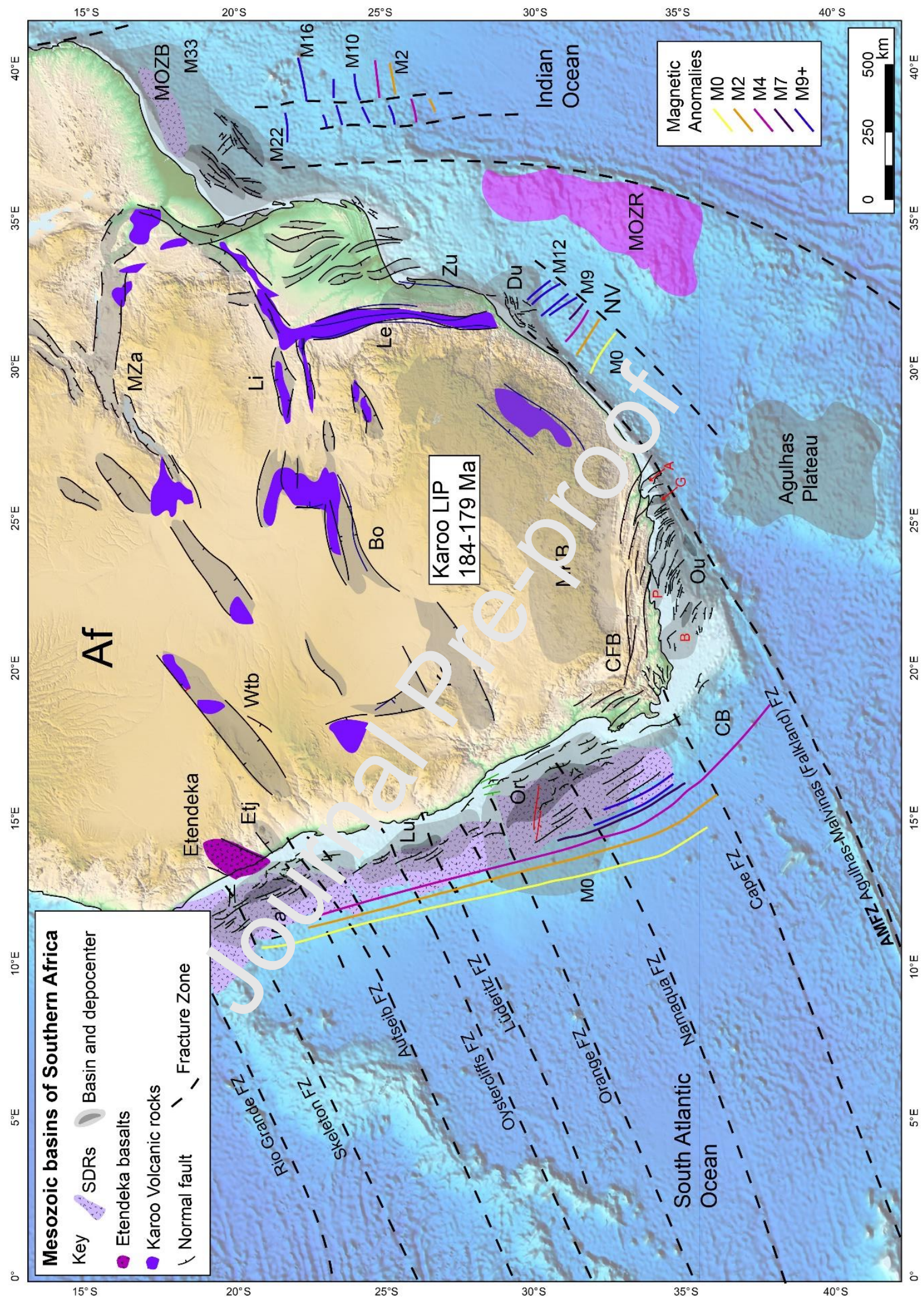

Fig. 5: Map of the main Mesozoic basins of southern Africa (Af). MKB: Main Karoo basin, Etj: Etjó, Wtb: Waterberg, MZa: Mid-Zambezi, Li: Limpopo, Bo: Botswana, Ka: Kalahari, Le: Lebombo, Zu: Zululand, MOZB: Mozambique basin, MOZR: Mozambique Ridge ,Du: Durban, NV: Natal Valley, Wal: Walvis, Lu: Luderitz, Or: Orange, CB: Cape basin, Ou: 
Outeniqua basin (sub-basins: B: Bredasdorp, P: Pletmos, G: Gamtoos, A: Algoa). After Goodlad et al. (1982), Smith et al. (1993), Frizon de Lamotte et al. (2015), Nairn et al. (1991), Mahanjane (2012), Mueller and Jokat (2017), König and Jokat (2006), Stollhofen et al. (1998), Davison and Steel (2018), Broad et al. (2012), Clemson et al. (1999), Koopmann et al. (2014), and Paton et al. (2016). Background topography from Etopo 1 (Amante \& Eakins, 2009).

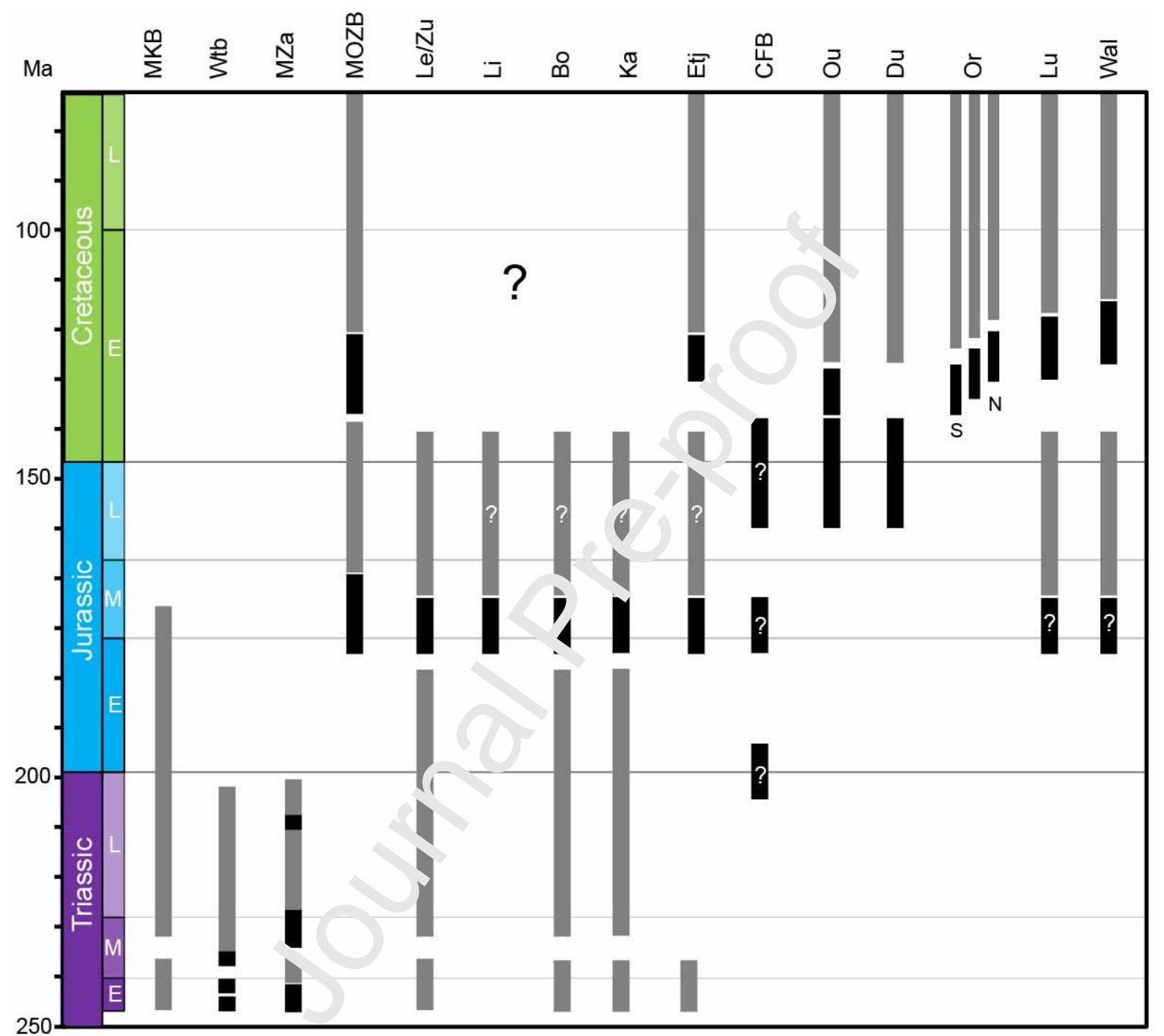

Fig. 6: Rifting chronology chart for the main Mesozoic basins of southern Africa. Black bars represent active rifting, while grey bars represent sag or other tectonic scenarios (e.g. drift, foreland). Main Karoo basin (MKB) after Catuneanu et al. (2005), and Duncan et al. (1997). Waterberg (Wtb) and Mid-Zambezi (MZa) after Zerfass et al. (2005) and references therein. Mozambique basin (MOZB) after Mueller and Jokat (2017). Limpopo (Li) and Lebombo (Le) monocline ages after Jourdan et al. (2007), and Klausen (2009). Botswana (Bo), Kalahari (Ka) and Etjó (Etj) basins after Catuneanu et al. (2005) and Smith et al. (1993). Etjó also records the Etendeca Zululand ( $\mathrm{Zu}$ ) and Durban (Du) after Broad et al. (2012). Etjó basin (Etj) after Renne et al. (1996). 
Offshore, the Outeniqua basin is formed of several WNW-trending halfgrabens, named from east to west: Algoa, Gamtoos, Pletmos and Bredasdorp subbasins (Fig. 5). These half-grabens are bounded by SW-dipping, en echelon listric faults, coherent with the extensively-reactivated thrusts of the Cape foldbelt further north (Fourché et al., 1992; Paton and Underhill, 2004). These faults display an arcuate shape, changing strike from WNW to NNW towards the east as they approach the AMFZ (Fig. 5). It had been suggested that the arcuate shape could be inherited from the Cape foldbelt (de Swardt and Mcl acilan, 1982), however, it seems more probably an effect of strike-slip along th', M'/I-Z (Broad et al., 2012). For the chronology of rifting, we follow here the revisw of Broad et al. (2012) and the references therein. Two synrift units are identified a -ross the different Outeniqua subbasins. The first synrift package starts with. fl vial sediments, overlaid by a shallow marine succession (dated Kimmeric riz,/Tithonian), topped by a fluvial section. The unconformity between synrift I and " is a regional unconformity of intra-Valanginian age, named 1 At1 offshore Solth .1f.ica (Broad et al., 2012; Jungslager, 1996), that was interpreted to mark the onset of strike-slip movement along the AMFZ (du Toit, 1979). The synrift II varies ^,nsiderably across the Outeniqua basin: shallow marine Valanginian-Hauterivian veds deposited in the Algoa sub-basin (Valicenti and Stephens, 1984), while deep-water Hauterivian shales are present in the Bredasdorp sub-basin (Broad et al., 2012).

The structure of the Atlantic margin of southern Africa, is marked by development of Early Cretaceous basins oriented NNW, parallel to the present-day coastline that evolved to a volcanic margin with abundant SDRs (Fig. 5), conjugate to the Argentinean margin. The Orange basin is the most prominent basin of the margin, occupying the western coast of South Africa and southern Namibia. Several 
half-grabens developed on continental crust, three of which have been drilled. The oldest dated sediments are Hauterivian lacustrine shales (Broad et al., 2012). Several SDR wedges develop to the west, on the continent-ocean transition. Absolute ages have not been published, but SDRS were interpreted to have emplaced in the Hauterivian (Broad et al., 2012). A Barremian biostratigraphic age is reported for some sedimentary packages interbedded with volcanic rocks in the Kudu well (McMillan, 2003). The breakup unconformity (named 6At1) is dated late Hauterivian and deeply erodes the more proximal eastern ainocenters (Broad et al., 2012). A complete review of the Atlantic volca ॥c margin was presented by Gladczenko et al. (1998) and Jungslager (1999) $7 \mathrm{IN}^{\mathrm{N}}$ more recently by Koopmann et al. (2014). The margin is transected by severa! ' SW-ENE oriented fracture zones (FZ, Fig. 5) which, similarly to what is obst ve $d$ on the Argentinean shelf, affect the COT and the outer continental cruc ${ }^{+} r^{\prime}$ omain. In volcanic segmented margins, the formation of FZ is a process interp "eted to be deeply related to breakup and SDR emplacement (Franke et al., 2013)

The distribution of "Dhs, however, is not continuous along the margin. Similarly to what is observ on the conjugate Argentinean margin, the southernmost segment of the Africa? mulantic margin, between the AMFZ and the Cape FZ seems to be lacking SDRs (Koopmann et al., 2014). The sedimentary basin on the slope and oceanic crust is referred to as the Cape basin (Fig. 5). On the shelf, the Outeniqua basin developed on continental crust but the crustal structure of the COT remains poorly constrained. To the north, the different FZ segmenting the margin present a dextral component. The oldest magnetic anomalies (M9 to M7, according to Koopmann et al., 2014) were determined in the southernmost segment with SDRs (just north of the Cape FZ) and disappear to the north, illustrating diachronism in the 
South Atlantic opening as originally postulated by Rabinowitz and LaBreque (1979) and also observed in the Pelotas basin by Stica et al. (2014).

To the north of the Orange basin, two other basins are described on the Namibian margin south of the Walvis Ridge, these are the Luderitz and Walvis basins (Fig. 5), which are also characterized by faults largely oriented parallel to the COT and to the present-day coastline (Clemson et al. , 1997). These basins are also interpreted to be of Neocomian age and conjugate with the Pelotas basin (see Cartwright et al., 2012). A thick pre-rift unit is interprote. on seismic data and correlated with Karoo-age sediments of the Namir, $1_{1}{ }^{4}$ and flood basalts of the Etendeka Group (Clemson et al., 1999). The Etenaika basalts are equivalent to the Serra Geral basalts of the Paraná basin (Firg. 2) and form part of the ParanáEtendeka LIP (Milner et al., 1995). A $1 \fallingdotseq 2 \mathrm{Ma}$ age, close to the ValanginianHauterivian boundary, was establishe $r$ ry Renne et al. (1996).

\section{MESOZOIC RIFTING IN SWI G 'JDWANA}

The amalgamation in the analyzed sector of the supercontinent of Pangea was completed in the Late Pain _oic (Fig. 7). The geodynamic scenario for the PermianTriassic is characteri-au by subduction along the Panthalassic margin (LaurentiaGondwana), the opening of the Neotethys ocean in the Permian (280 - $260 \mathrm{Ma}$, Fig. 7), followed by rifting along the Central Atlantic with closure of the Paleotethys in the Triassic (230 - $220 \mathrm{Ma}$, see Riel et al. 2018 and references therein).

In SW Gondwana, the Early Permian San Rafael tectonic phase produced eastward expansion of the volcanic arc and intense deformation and orogenic building (circa $290 \mathrm{Ma}$ ). This event has been interpreted by Ramos and Folguera (2009) as a case of flat slab subduction in the Late Paleozoic. The term "Gondwanide 
orogeny" was introduced by Keidel $(1921)$ and also used by Du Toit $(1927,1937)$ to gather all late Paleozoic deformation events (in the SW Gondwana margin) and to explain deformation along the Ventania-Cape thrust system (VCS in Fig. 7). Deformation along this system is diachronous, Late Permian in the Ventania system of central Argentina (Dimeri et al., 2005) spanning until the Early Triassic in South Africa (Hansma et al., 2016).

Absolute counterclockwise rotation of Pangea since the Middle Permian (Marcano et al., 1999) with a rotation pole in northern Snı. America (Torsvik et al., 2012, Fig. 7) caused a decrease in the convergenc s locity at the SW Gondwana margin (inducing retroarc extension) and, on the inntrary, compression along the Laurentian margin (Riel et al., 2018). In this conte, +. normal andesitic arc volcanism along the Gondwana margin in the Early $D_{c} m$.an experienced arc expansion to the south and east, and an increase in . hvr, ite abundance. Silicic volcanism is gathered in the Choiyoi Magmatic Province (' '7y et al., 1989; Sato et al., 2015), emplaced in a subduction-related extensional arc catting, and produced by slab roll-back after the Gondwanide orogeny (Rocr: $r$ el al., 2015; del Rey, 2019).

The Mesozoic was a'l era of overall continental dispersion, with continuous subduction of the pa'ou-Pacific plate (Panthalassa) below SW Gondwana. In the following sections we present four paleo-tectonic maps depicting the rifting evolution of the different Mesozoic basins in the area of study (AOI in Fig. 7). Besides the Early Cretaceous South Atlantic breakup, we intend to illustrate the different rifting stages that occurred since the Early Mesozoic. We refer to Frizon de Lamotte et al. (2015) for a review of the initial Pangea breakup in other regions which remain out of the scope of this study. 


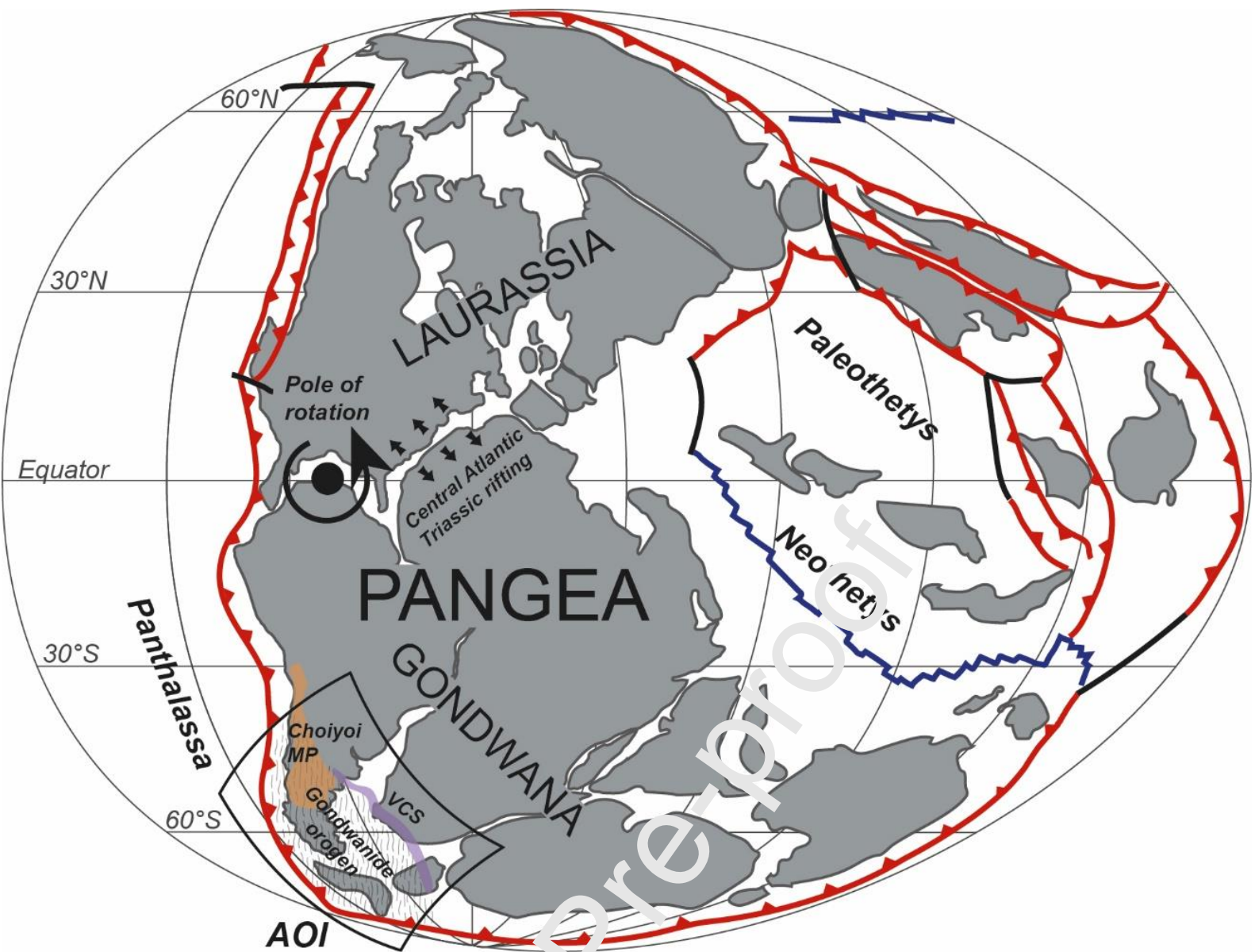

Fig. 7: Paleo-tectonic map of the Pangea s !percontinent at the end of the Paleozoic (circa $250 \mathrm{Ma}$ ) after Riel et al. (2018). Euler $r^{+}$ation pole of Pangea from Torsvik et al. (2012). Note the location of the Area of Interes $(\neg ? !)$, the Gondwanide orogen, the Choiyoi Magmatic Province and the Ventania-Cape f_'tu=.'. (VCS).

\subsection{Triassic-Early Jıras ic Rifting}

In this first riting or ase we gather all rifting events taking place throughout the Triassic, with Early-to '-ate Triassic rifting (sensu lato) indicated by faults mapped in purple in Fig. 8 and differentiated from faults active since the Late Triassic rifting (mapped in red in Fig. 8). Three groups of depocenters are indicated: a series of depocenters in SW Gondwana retroarc aligned sub-parallel to the margin, and two sets of depocenters orthogonal to the margin. The retroarc depocenters (1 in Fig. 8) include the Cuyo, Bermejo, Neuquén, and Deseado basins and some recently identified Late Triassic depocenters in the Malvinas basin area. The other two extensional features, oriented at high angles with the margin, are: the axis formed by 
the Santa María (Brazil) and the Waterberg and Mid-Zambezi basins extending into East Africa as part of the Karoo I system (2 in Fig. 8) sensu Frizon De Lamotte et al. (2015); and the Permian-Early Triassic Cape fold-and-thrust belt, and its extension into South America known as the Ventania system, reactivated throughout the Mesozoic (3 in Fig. 8).

Following a period of flat slab subduction that lasted between the Late Carboniferous and the Early Permian (Ramos and Folguera, 2009), slab steepening associated with lower crust delamination produced the rhyclitic flare of the Choiyoi Magmatic Province (Fig. 7), widely distributed in C fllı; Chile and Argentina (see Kay et al., 1989; and Sato et al., 2015 for furthor : oference). In northern Chile, the Triassic arc is present in the Coastal Cordillera ,Maksaev et al., 2014). In central Chile, the volcanic arc was establisher ir ie the Early-Middle Triassic in the Domeyko Range (Fig. 8), and migra. `d westward in the trench direction, towards the Coastal Cordillera in the Early Jura sic (Oliveros et al., 2018; Fig. 8). The presence of a Triassic arc and its tremh-" ard migration until the Early Jurassic was also observed in the Antarctic Jenınsula by Storey et al. $(1992,1996)$ and recently reassessed by Bastias el al (2020), who linked these observations to a steepening of the subducting plai? and highlighted the importance of subduction-plate boundary forces in the initial stages of Gondwana breakup. 


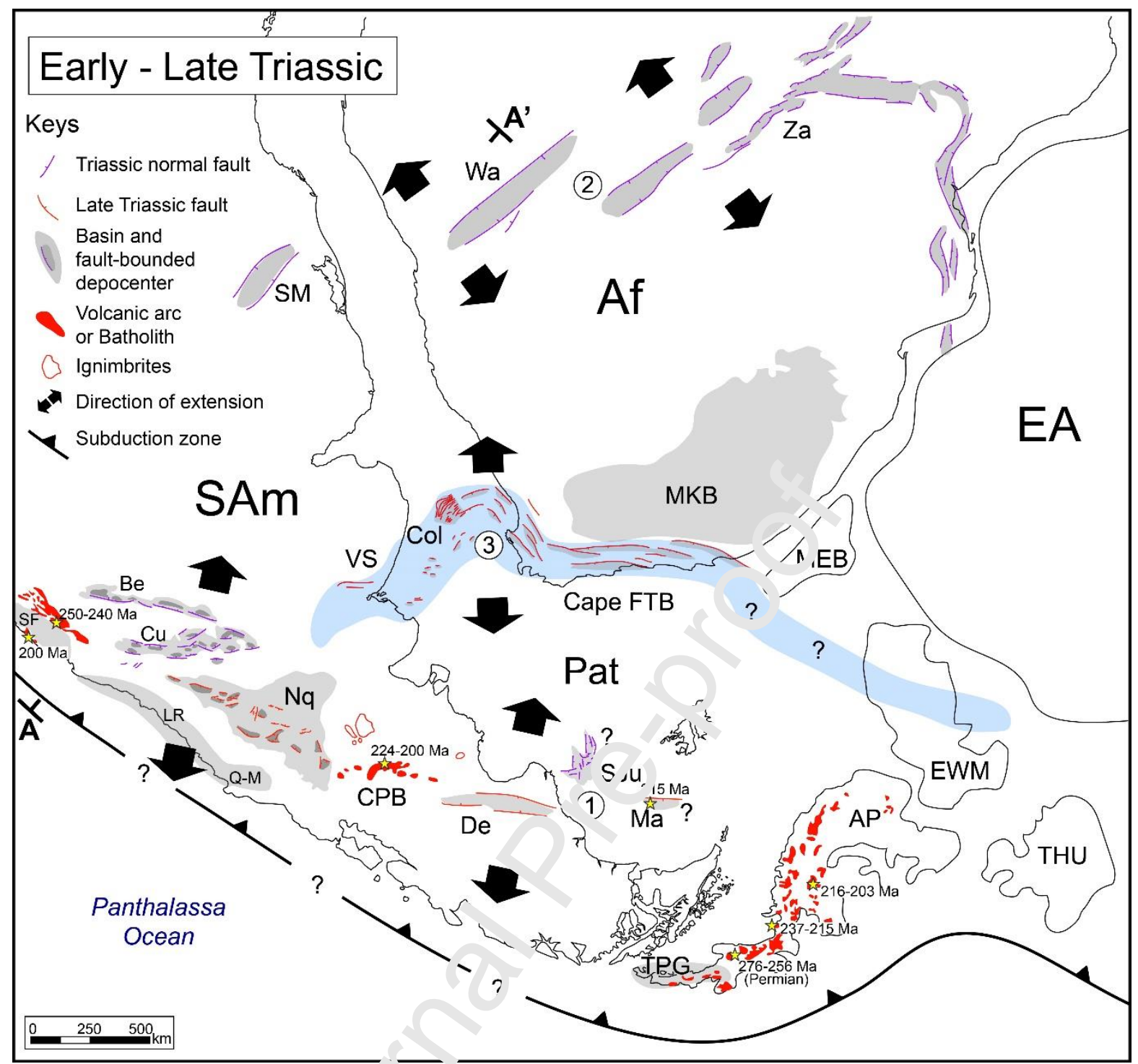

Fig. 8: Paleo-tectonic reconstruction of SW Gondwana at $200 \mathrm{Ma}$. Africa in its present-day position. Gondwana fit afte: Da <iel et al. (2013). Triassic volcanic arc in Central Chile after Oliveros et al. (2018), C,errva Patagonian Batholith (CPB, age after Rapela et al., 2005). Fore and intra-arc bains in. Chile: SF: San Felix-Rivadavia basin, LR: La Ramada, Q-M: EI Quereo-Los Molles basin (after Charrier et al., 2014). Volcanic arc in the Antarctic Peninsula (AP) and extension of the Trinity Peninsula Group (TPG) basin the after Bastias et al. (2020), Storey et al. (1992), Millar et al. (2002), Flowerdew et al. (2006), and Riley et al. (2012). Basins develop in a back-arc: Cuyo (Cu), Bermejo (Be), faults after Uliana et al. (1995); or intracratonic setting: Santa Maria (SM), Waterberg (Wa), Zambezi (Za), after Zerfass et al. (2004), San Julián (SJ, after Micucci et al., 2011). Late Triassic-Early Jurassic basins: Neuquén (NQ, Precuyano cycle, faults after Bechis et al., 2014), Deseado (De) and Malvinas (Ma) basins after Uliana et al. (1989). The previously compressive faults of the Ventania (VS) - Cape Permian-Early Triassic fold and thrust belt (FTB, in blue) have been extensionally reactivated in the Colorado (Col) and Cape area (Lovecchio et al., 2018; Paton, 2006). MKB: Main Karoo basin. Tectonic blocks: South America (Sam), Patagonia (Pat), Africa (Af), Maurice Ewing Bank (MEB), Eastern Antarctica (EA), Ellsworth-Whitmore Mountains (EWM), Antarctic Peninsula (AP), Thurston Island-Eights Coast (THU). 1, 2 and 3 are different groups of basins referred in the text. 
A series of extensional basins developed in the retroarc during this stage (Franzese et al., 2003). The Bermejo and the Cuyo basins in western Argentina have been related to the evolution of the Gondwanide active margin (Fig. 9; Zerfass et al., 2004). U-Pb zircon ages for the Cuyo basin indicate several pulses of rifting throughout the Middle Triassic (Spalletti et al., 2008; Barredo et al., 2012). An Early Triassic age is suggested for rift initiation in the Bermejo basin (Stipanicic and Bonaparte, 1979). Recent U-Pb zircon ages from tuffs interbedded in the late synrift units (sensu Milana and Alcober, 1994) indicate Middle th Lite Triassic ages of 236$234 \mathrm{Ma}$ (Marsicano et al., 2016). The location and th: $\mathrm{c}^{-i}$ entation of these basins is a consequence of crustal heterogeneities as they ${ }^{\prime} \in:$ ? emplaced along the hangingwall sutures between Paleozoic terranes (Ra.nos and Kay, 1991). Triassic depocenters develop as well in central a id northern Chile (see Charrier 1979;

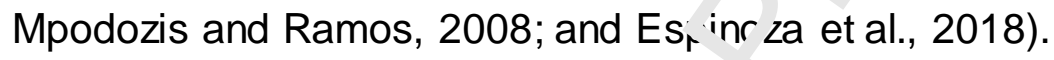

\section{A Late Triassic}

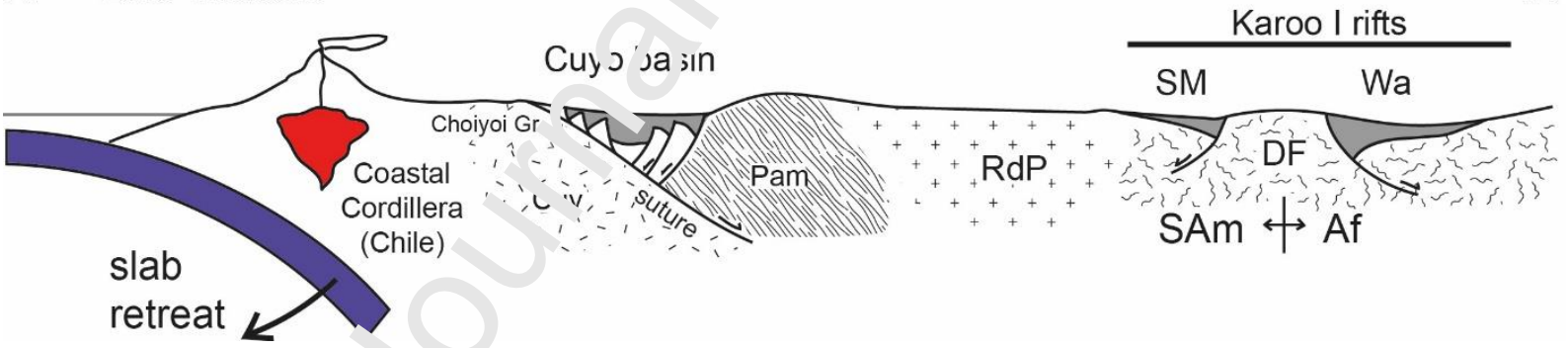

Fig. 9: Schematic cros section of the SW Gondwana margin for the Late Triassic (not to scale). See location ir. $F_{1 g}$. 8. The magmatic arc is represented by the Coastal Cordillera Batholith (Chile); extension took advantage of the Early Paleozoic Cuyania suture to form the Cuyo basin; Intracontinental rifting in Africa produced the Karoo I rifts. After Ramos and Kay (1991), Oliveros et al. (2018) and Zerfass et al., (2004). See keys on cratones and tectonic blocks in Fig. 2.

In Patagonia, there is still discussion regarding subduction being active during this period. The granitoids of the Central Patagonia Batholith (Stipanicic and Methol, 1972; Rapela and Kay, 1988), were emplaced in the Late Triassic (200-224 Ma, Rapela et al., 2005) in the North Patagonian Massif and form a NW-directed batholith 
that has been associated with either an intraplate extensional setting (Rapela et al., 1992; Kay, 1993), or with a subduction-related setting (Rapela et al., 1991; Zaffarana et al., 2014). Navarrete et al. (2019) have recently proposed that this batholith formed in a flat-slab setting. However, a flat-slab subduction would preclude any arc magmatism at more than $700 \mathrm{~km}$ from the trench, where the subducted slab would be completely dehydrated, and so cease to interact with the asthenospheric wedge, as shown in several Cenozoic flat-slabs (Ramos et al., 2002; Ramos and Folguera, 2009). The slab partial melting proposed by Navarrete ot ?l. (2019) is unrealistic, since only very young slabs should melt, as shown oy kay et al. (1993). Besides, contraction as proposed does not seem probahle for the Late Triassic given the overall extensional setting in the Gondwana's ma in retroarc at this time (Fig. 7), and in particular the Late Triassic riftinc .. I'ie Malvinas basin (Lovecchio et al., 2019).

In the Deseado massif (De 1.: Fig. 8), the Mid-Late Triassic El Tranquilo rifting event formed a NNW-orientad $r_{\text {.ft }}$ filled with fossil-rich continental deposits interbedded with volcanic rc $k$ ks (Haller, 2002). El Tranquilo probably developed as a late stage of the Permia uxtension recorded in the Deseado massif by the La Golondrina rifting (Hu muvc and Constantini, 2001). Offshore, the San Julián basin might record a similar stratigraphy but its depocenters remain unexplored. Late Triassic synrift volcanic rocks were recently reported by Lovecchio et al. (2019) in the Malvinas basin, who interpreted a retroarc extensional setting.

Moving to the intracratonic area, Zerfass et al. (2005) proposed the correlation of the Triassic Santa Maria basin with the Waterberg and Mid-Zambezi Karoo I basins in Africa. Guillocheau et al. (2018) extended this correlation for other basins in Eastern Africa, India and Australia. Considering spatial orientation and synchronicity, 
there seems to be a relationship between the formation of Karoo I depocenters and rifting and breakup along the Central Atlantic (between NW Africa and eastern North America, see Fig. 1).

Following the end of compression in the Cape fold belt in the Early Triassic, negative inversion of the compressive structures has been identified in Africa by De Wit and Ransome (1992) both onshore on the Cape fold belt itself, and offshore towards the south, in the Outeniqua basin. The chronology of this extensional reactivation is poorly constrained. Offshore in Outeniqus 1.2 oldest datable marine sediments are of Late Jurassic age, but onshore the st. ${ }^{\prime}$ Imentary infill indicates more proximal environments: the Enon Fm. conglomeratt = of Late Triassic-Jurassic age (Dingle, 1973). Reactivation probably took pla?e in several pulses (Fig. 6). Extensional reactivation of previously comrre :sive structures has also been identified offshore Argentina, in the Colorado : ₹š.n, by Pángaro and Ramos (2012), Pángaro et al. (2016) and Lovecchio et al. (¿'18) and below the Orange basin by Paton et al. (2016).

In the Neuquén basir, Lale Triassic to Early Jurassic rifting is recorded by the Precuyano cycle. D'Elia $t^{+}=$l. (2015) suggested rifting diachronism since the Late Triassic until the Ea.'ly urassic from north to south. However, the occurrence of Triassic depocenters also in the south (Sañicó-Piedra del Águila, see Carbone et al., 2011) challenges this interpretation. We depict all Triassic depocenters restricted to a strip in the west and oriented subparallel to the subduction zone (Fig. 8). In the Huincul ridge area, along the southern edge of the Neuquén basin, some NW-SE oriented Late Paleozoic structures associated with the Patagonia collision (Mosquera and Ramos, 2006) were reactivated in an extensional setting (Pángaro et al., 2009). This Late Triassic rifting event was correlated with the extensional reactivation of the 
offshore portion of the Ventania-Cape fold belt in the Colorado basin by Lovecchio et al. (2018).

\subsection{Early - Middle Jurassic Rifting}

In the Early Jurassic, two different but regionally important events were taking place in Gondwana: Africa was affected by the Karoo II rifting (sensu Frizon de Lamotte et al., 2015) as a consequence of the impingement of the Karoo mantle plume, while extension was also affecting the SW Gondwana retroarc with emplacement of the Chon Aike silicic magmatic provinne isensu Kay et al., 1989; Pankhurst et al., 1998) as demonstrated by Gust ㄷ ㄱ. (1985) and Uliana et al. (1985)

We have mapped the maximum extent if I’ $^{\prime}$ Karoo volcanic rocks (Fig. 10) and obtained a diameter of influence of $\mathrm{hr}$, mantle plume of about $2,000 \mathrm{~km}$, consistent with estimations of White ard McKenzie (1989). According to Frizon de Lamotte et al. (2015), various obst vations such as regional doming and volcanism preceding rifting, are evidence of 3.1 active rifting process, with plume impingement being the triggering mechai. sm ior the Karoo II event. The detection of a three-way junction of dyke swarme $1, r_{\text {-ast }}$ Africa that could be interpreted as a triple junction (Elliot and Fleming, $\iota^{\Upsilon}(\mathcal{u}$, Figs. 1 and 10) has increased the debate. Jourdan et al. (2004) suggest that the Jurassic Karoo igneous dyke swarms were emplaced along reactivated Proterozoic mobile belts between cratons, and thus the variety of dykes' orientations would not be due to a triple junction but conditioned by the basement fabric. The Limpopo area remains however the geographic center of volcanic activity and the predominant orientation of rifts seems to be ENE (Fig. 10). Storey et al. (1992) relate the Karoo rifting to subduction processes, a rifting that would have been accentuated, but not triggered by the Karoo plume. 
In the Mozambique basin area (Fig. 10), rifting evolved and succeeded throughout the Early - Middle Jurassic, with SDR emplacement in the Bathonian and normal oceanic crust accretion since the Callovian (Mueller and Jokat, 2017).

On the southwestern margin of Gondwana, a new phase of extension is recorded in the Neuquén basin during the Early Jurassic: the Cuyano cycle. This extension is associated with larger depocenters formed by reactivation of some Precuyano structures (Vergani et al., 1995). The Neuquén basin and the Liassic Chubut basin, further south, developed behind the samo ¿arly Jurassic magmatic arc, represented by the Patagonian Subcordilleran Bi.ıIı'Itn (Fig. 10 and 11).



Fig. 10: Paleo-tectonic reconstruction of SW Gondwana in the Early-Mid Jurassic. Gondwana fit after Dalziel et al. (2013). Eastern Africa and Eastern Antarctica are impacted by the Karoo 
mantle plume (purple), coeval with the Ferrar LIP and Chon Aike Magmatic Province (in dark and light pink respectively, Pankhurst et al., 2000). Karoo rifts: Kalahari (Ka), Botswana (Bo), Limpopo (Li), Lebombo (Le), Stormberg (Sto), Mozambique (MOZB), ages from Jourdan et al. (2005), and Mueller and Jokat (2017). In South America, this is a period of intense rifting in the Colorado (Col), Salado (Sal) and Neuquén basins (Nq, Cuyano cycle). Also in the Cañadón Asfalto (CA) and San Jorge (SJ) basins. The Liassic Chubut basin (Ch) is a backarc basin for the arc-related Patagonian Subcordilleran Batholith (PSB, age after Rapela et al. (2005). Dykes of this age reported in the Malvinas (Falkland) Islands (Ml; Ramos et al., 2017). The Tobífera Series in the Malvinas (Ma) and Austral (Au) basins also developed at this time (Pankhurst et al., 2000; Uliana et al., 1989).

\section{B Northern Patagonia: Early Jurassic}

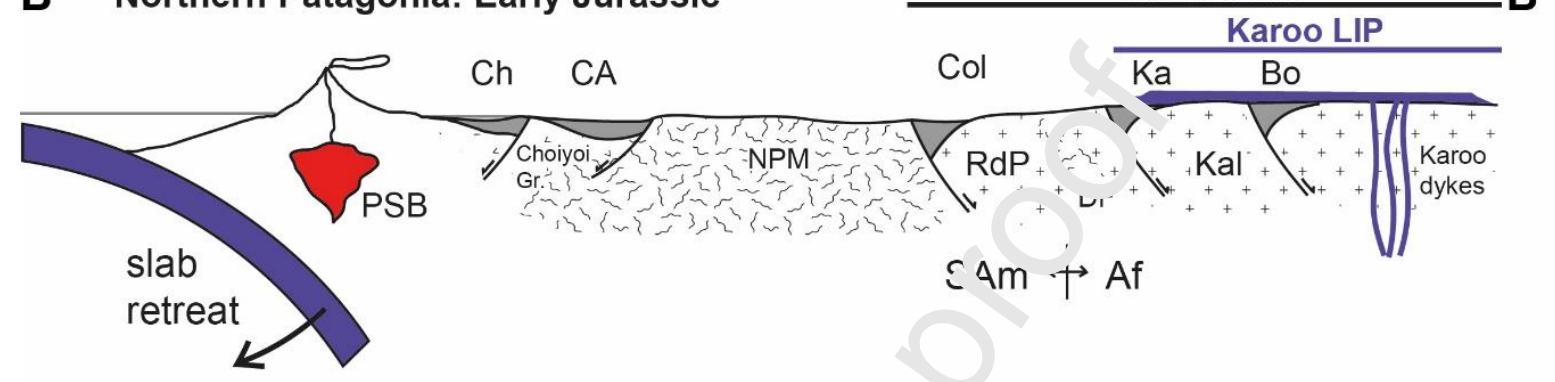

\section{Southern Patagonia: Early-Mid Jurassic}

$C^{\prime}$

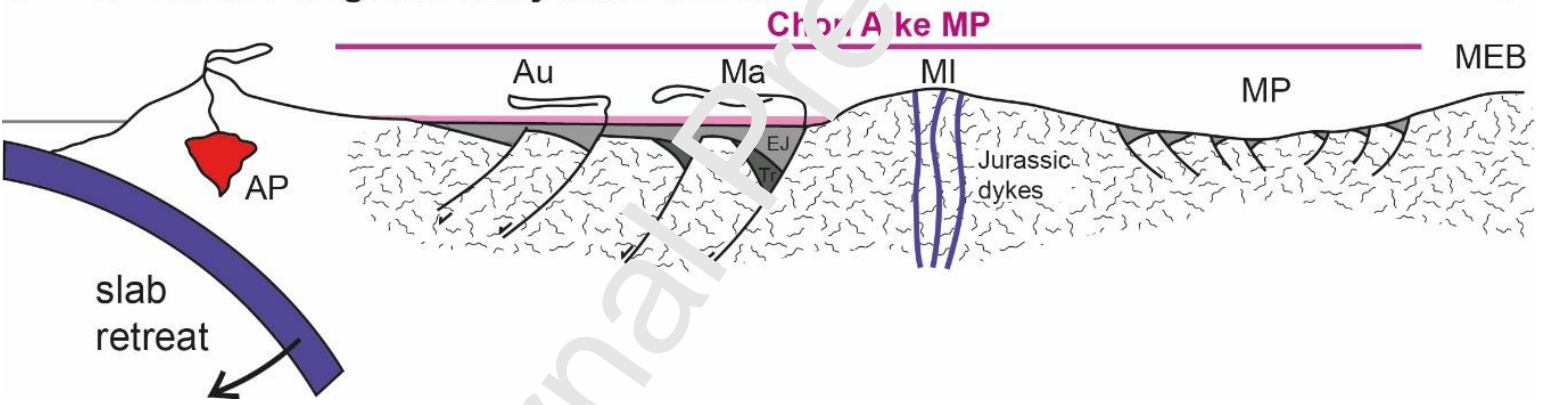

Fig. 11: Schematic cross sec: ins of the SW Gondwana margin for the Early-Mid Jurassic at two different latitudes. See low . ?tion in Fig. 10. B-B' is a transect across northern Patagonia, with a magmatic arc repres $? n$.ed by the Patagonian Subcordilleran Batholith, the retroarc Chubut and Cañadón A falt basins and the Karoo II basins in Africa (Kalahari, Botswana) associated with the Ka: ' $^{\prime}$ plume and the Colorado basin (offshore Argentina). C-C' is a transect across south .... Patagonia, with a magmatic arc in the Antarctic Peninsula and retroarc extension associated with emplacement of the Chon Aike Magmatic Province. Early Jurassic dykes are reported in the Malvinas (Falkland) Islands. Extension between the islands and the Maurice Ewing Bank (Malvinas -Falkland- Plateau) occurs at this time induced by a slab-tear between Patagonia and the Antarctic blocks. Keys for basins and tectonic blocks as in Fig. 2, 3, 5 and 10.

Huge magmatic volumes where extruded during the Early to Middle Jurassic in Patagonia as part of the Chon Aike magmatic province (Fig. 10 and 11; Pankhurst et al., 2000). Early Jurassic acidic volcanism in the North Patagonian Massif is coeval with the arc volcanism of the Patagonian Subcordilleran Batholith (Rapela et al., 
2005). Suárez and Márquez (2007) proposed that the Liassic Chubut basin developed in the retroarc region of the coetaneous Patagonian Subcordilleran Batholith. According to these authors, the closure of the Chubut basin in the Middle Jurassic coincides with a westward migration of the magmatic arc, from a position in the extra-Andean region towards the Patagonian Cordillera, and a rotation from a NNW strike to a nearly N-S direction.

Slab retreat is also coherent with the retroarc extensional regime observed in other coetaneous basins developed further south. If we interp ret the orientation of the NW-directed mafic dykes in the Malvinas (Falklar 1 ) 'slands (Musset and Taylor, 2004; Stone et al., 2008) as indicators of the palen-_tress field (sigma 3) for the Early Jurassic, a diachronism can be interpreted betw'ət? these structures and the Early to Middle Jurassic synrift infill, of the $A^{\prime}$ isi al (Magallanes) and Malvinas basins (Lovecchio et al., 2019). Thermoci ror.ological data from the Malvinas (Falkland) islands (Thomson et al., 2002) in wicate exhumation in the Early-Middle Jurassic, consistent with shoulder uplift, mith r,spect to the Malvinas basin. Further west, in the Austral (Magallanes) basin, : 1alkuwski et al. (2015) and Zerfass et al. (2017) highlight diachronism of rifting initla ${ }^{+i}, .$, and bimodal volcanism towards the northwest, as well as diachronism of OC: back-arc basin, which also becomes younger towards the north (see Fig. 12). In this framework, Lovecchio et a. (2019) interpret the overall diachronism of rifting initiation from east to west as a product of differential rollback below Patagonia (Echaúrren et al., 2017) triggered by a slab tear that would have been located between Patagonia and the Antarctic territories. The proposed slab tear would have been represented at the overriding plate's surface by a regional strike-slip fault zone, which is also necessary to accommodate lateral displacement between Eastern and Western 
Gondwana that break apart at this time (König and Jokat, 2006) during the opening of the Mozambique basin (Fig. 12).

For the Antarctic Peninsula, Storey et al. (1992) also observe a westward migration of the Jurassic arc compared to the Triassic arc location (see Fig. 8 and 10 for comparison) and development of back-arc extension and magmatism. The Early Jurassic magmatism in the Antarctic Peninsula has been also correlated with the subduction-related Patagonian Subcordilleran Batholith in Patagonia by Riley et al. (2016).

The Colorado and Salado basins are loc attr between, but presumably outside, the areas affected by magmatism of the Karoo LIP and the Chon Aike Magmatic Province (MP, Fig. 10). This Early-M:au Jurassic rifting stage has been interpreted as responsible for the formaticn if the main depocenters of the Colorado and Salado rifts (Lovecchio et al., $2 C^{1} 8^{\prime}$. This event is associated with SW-NE to N-S extension in the present-day Soutı. American reference frame. In a paleo-tectonic perspective (Fig.10), these rasi. ${ }^{\circ}$ are aligned with the ENE-oriented Karoo II Kalahari, Botswana, Limpor' arıd Mozambique rifts in Africa. Following this rationale and considering their sumuruny and spatial relationships, the Colorado and Salado rifts could be the wesi rrmiost extension of the Karoo II rift system (Fig. 10).

\subsection{Late Jurassic}

In the Late Jurassic, oceanic crust accretion was already occurring in the Mozambique channel in East Africa (see Mueller and Jokat, 2017, and references therein). The dextral strike-slip fault zone that accommodated relative displacement between East and West Gondwana changed from strike slip to spreading and formed the Weddell Sea (Fig. 12, see Livermore and Hunter, 1996; König and Jokat, 2006; 
Eagles and Vaughan, 2009). According to the slab-tear model recently published by Lovecchio et al. (2019), oceanic spreading of the Weddell Sea would have been triggered by the thermal anomaly produced by the asthenospheric window introduced by the vertical slab tear. There are still many uncertainties regarding the opening of the Weddell sea. Most of the conjugate passive margin on southern South America was consumed by subduction under the Scotia plate during the Cenozoic, while the other conjugate margin in Antarctica is covered by ice most of the year making it

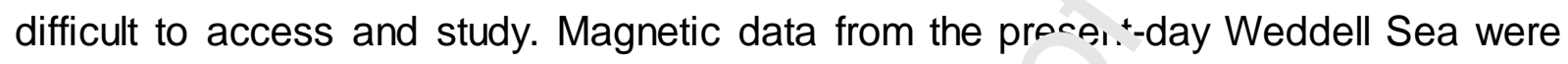
documented by Livermore and Hunter (1996), Ghide'ia ?t al. (2002) and Jokat et al. (2003). A possible SDR wedge associated with the Gondwana breakup is also illustrated in Fig. 12 (Explora wedge, Hinz, 1981; K.'stoffersen et al., 2014).

On the Pacific margin, arc miçra'nr. to the west continued in central Patagonia, with the establishment $\iota^{f} t^{\prime}$ ie Andean Patagonian Batholith in the Late Jurassic (PB in Fig. 12). Again v. osterly arc migration and clockwise rotation is observed, suggesting differenti-1 r.'l'Jack of the subducted slab (Rapela et al., 2005; Echaúrren et al., 2017). 


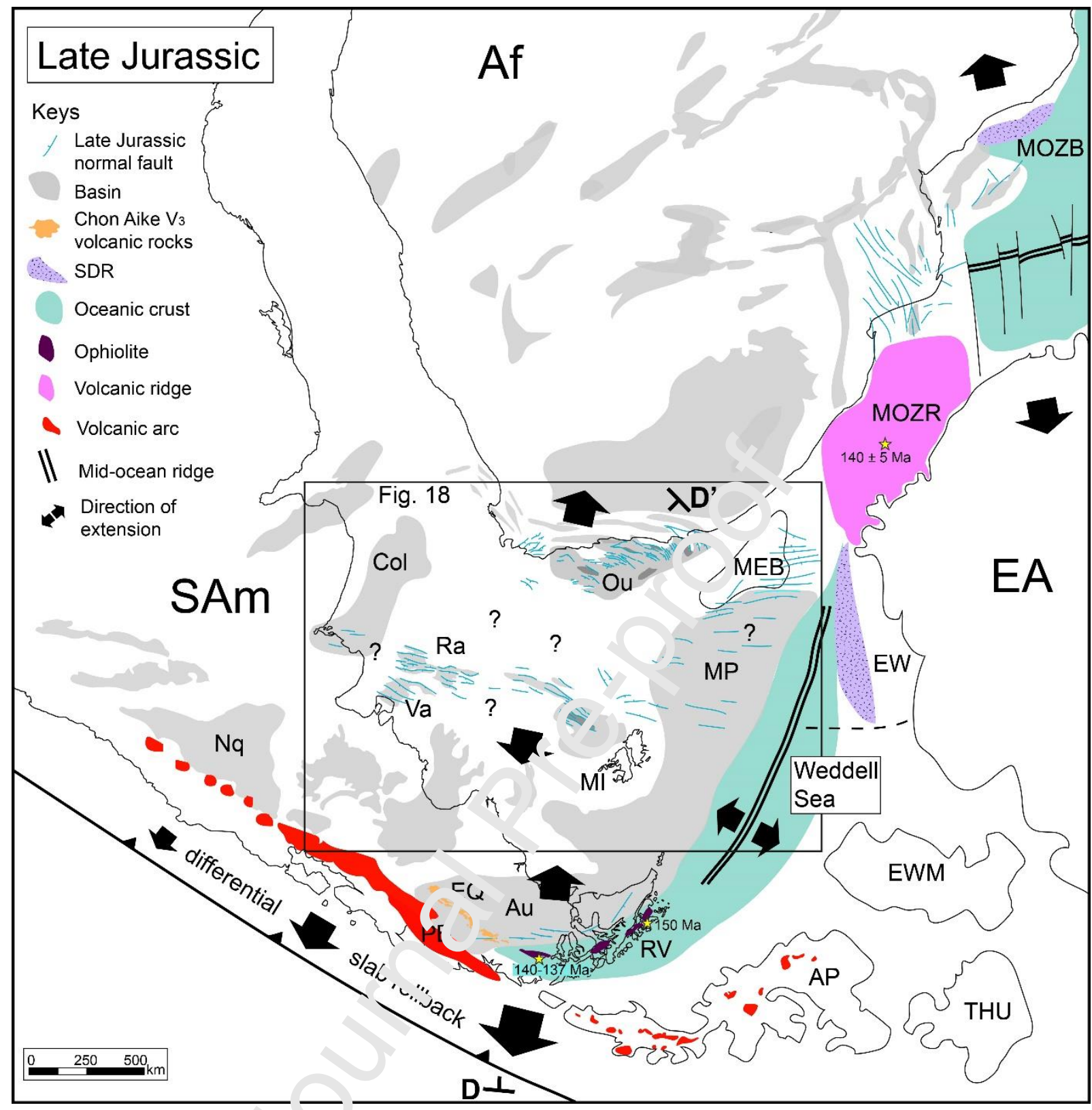

Fig. 12: Paleo-tectonic reuvistruction of SW Gondwana in the Late Jurassic. Gondwana fit after König and Jokat ( $(J 6)$. The Mozambique channel opens as Antarctica moves south. Wrenching along the South America-Antarctica limit ends with seafloor spreading and the origin of the Weddell sea. Faults in the Mozambique area after Macgregor (2017) Mozambique Ridge (MOZR) age after Mueller and Jokat (2017). The Rocas Verdes (RV) back-arc basin develops to the west of the Austral basin. Schematic Patagonian Batholith (PB) after Rapela et al. (2005). Oceanic crust ages after Mukasa and Dalziel (1996) and Stern et al. (1992). Oblique rifting produced the formation of the Rawson/Valdés ( $\mathrm{Ra} / \mathrm{Va}$ ) and Outeniqua ( $\mathrm{Ou}$ ) basins in the core of the Late Paleozoic Gondwanides orogen. Wrenching along the future Agulhas-Malvinas (Falkland) fracture zone (AMFZ) will release South America from Africa and produce the breakup along the Neoproterozoic mobile belt. The black rectangle shows the location of the zoom presented in Fig. 18. 
Rifting associated with opening of the Rocas Verdes back-arc basin in the Late Jurassic (circa $160 \mathrm{Ma}$ ) is represented by the bi-modal magmatism observed in the El Quemado complex and its equivalents: the Lago La Plata Fm (Ramos, 1981) further north and the lbañez Fm in Chile (Pankhurst et al., 2000). Rifting succeeded with the onset of oceanic crust accretion in the Rocas Verdes marginal basin since $150 \mathrm{Ma}$ (Fig. 12, 13, Calderon et al., 2016). Although the Rocas Verdes basin displays a curved shape in its present day configuration (Fig. 12), it was probably a N-S elongated basin (see Vérard et al., 2012). The continu.'ty of a single mid-ocean ridge between this back-arc basin and the Weriat" sea seems possible, as suggested by Diraison et al. (2000), and Eagles (c?16). However, these basins are related to two tectonically independent mechrnı ns: the Rocas Verdes back-arc basin produced by rollover of the subduct $n_{i} r$.ate, and the Weddell Sea generated by spreading of an active oceanic . $\mathrm{dr}$, e between Eastern and Western Gondwana (Fig. 1). The solution proposed hy Vérard et al. (2012), depicts these two independent oceanic basins, hor is ver the amount of extension (final width) and shape they infer for the Rc as Verdes basin (they favor a N-S elongated back-arc basin all along the maryin, seems unlikely. The Rocas Verdes basin was an asymmetric basin, wi re rifting and oceanic spreading started earlier in the south (see Malkowski et al., 2015), producing more cumulative extension than in the north, thus generating a triangular shaped basin (also consistent with the clockwise rotation of the arc in northern Patagonia between the Early and Late Jurassic; Echaúrren et al. 2017; Lovecchio et al., 2019). The northernmost obducted oceanic crust outcrops south of $51^{\circ} \mathrm{S}$ (Sarmiento Complex), suggesting that the back-arc basin could not have reached further north than $48^{\circ} S$ latitude (see Fig. 3 and 12) while Vérard et al. (2012) suggest the back-arc basin reached north of $20^{\circ} \mathrm{S}$ latitude. The impact of the 
Patagonian orocline in curving the remnants of the Rocas Verdes basin in the south, plays an important role and remains a matter of discussion out of the scope of this study (Ghiglione and Cristallini, 2007; Torres Carbonell et al., 2016; Eagles, 2016). In our reconstruction (Fig. 12) we present the Patagonian orocline and the Fuegian Andes with their present-day shape.

In Africa, Late Jurassic marine sediments are recorded in the Outeniqua basin. In a paleo-tectonic perspective (Fig. 12), regardless of the continental fit used, fault orientations in the Outeniqua and in the Rawson/Valdóc L ?sins in South America seem parallel, consistent with largely present-day pi-s extension for African (ENE extension for present-day South American) refaisnce frame. As suggested by Continanzia et al. (2011), we associate both basirs with a single oblique rifting event initiated in the Late Jurassic (Fig. 12 and 3) The extensional faults interpreted by Biddle et al. (1996) around the Maric s Ewing Bank (MEB in Fig. 12) and in the Malvinas (Falkland) Plateau could 1,.?ve started earlier or belong to this same rifting event. Also the North Rift of the . Ir,rth Malvinas (North Falkland) basin develops at this stage (Lohr and Unc' rrhlii, 2015; Richards and Hillier, 2000). A northern connection between this vicin and the Atlantic rift has been suggested by Becker et al. (2012). 
E Patagonia: Late Early Cretaceous

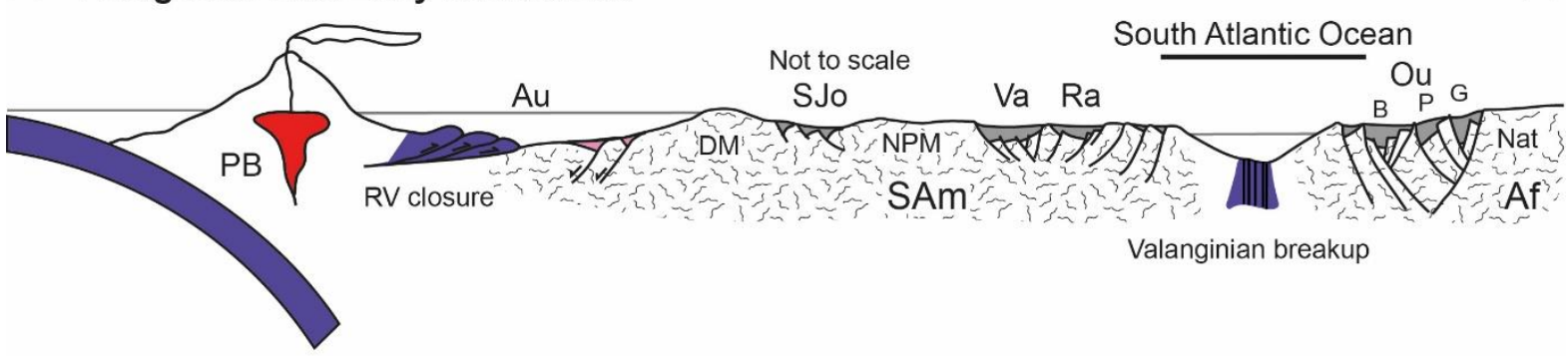

D Patagonia: Late Jurassic

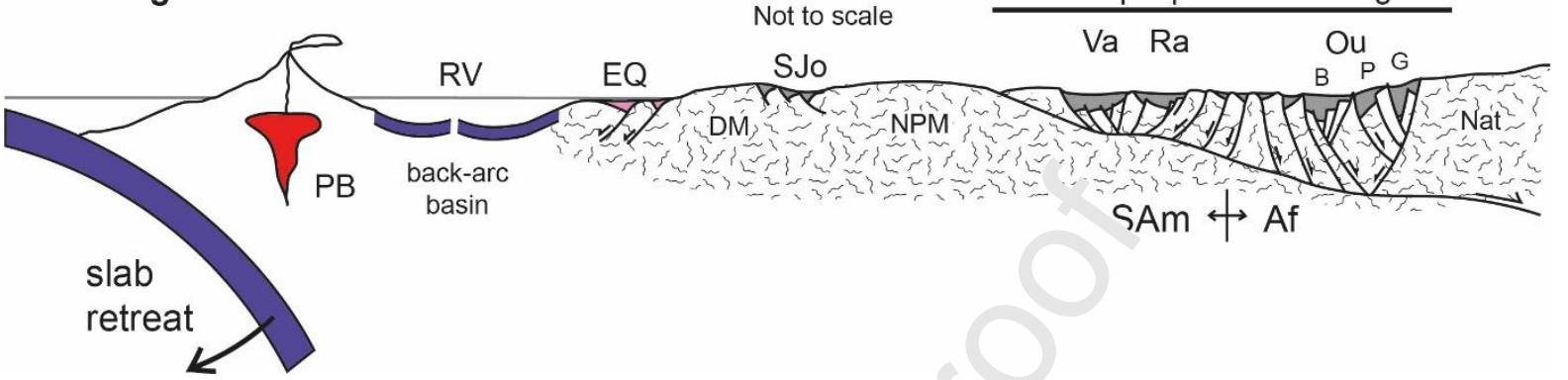

Fig. 13: Schematic cross sections of the SW Gondwa ra margin (not to scale). D-D' is a transect across SW Patagonia in the Late Jurassic. wit, a magmatic arc represented by the Patagonian Batholith, retroarc extension marked $b$, the emplacement of El Quemado complex and equivalents and spreading in the $\Gamma_{\text {. }}$ sas Verdes back-arc basin. Oblique rifting in the Rawson/Valdés and Outeniqua basin was srf cursor of the South Atlantic opening. See location in Fig. 12. Modified after Ramos '9si), Continanzia et al. (2011) and Broad et al. (2012). E-E' is a generalized transect a. rors SW Patagonia in the Early Cretaceous (sensu lato), compression in the SW Gondwana 1. argin is evidenced by the closure of the Rocas Verdes basin and onset of a forelanc setting in the Austral-Magallanes basin in the Late Early Cretaceous. Spreading in th $=$ southern South Atlantic Ocean initiated in the Valanginian. See partial location :.. Fly. 15. Keys for basins and tectonic blocks as in Fig. 2, 3,5 and 15.

\subsection{Early Cretacer u:}

The main tectori : event taking place in the Early Cretaceous is the opening of the South Atlantic Ocean between Africa and South America. This process has been interpreted to be diachronous, initiating in the south and progressively propagating northwards (Rabinowitz and LaBreque, 1979). The southern South Atlantic is a typical magma-rich margin (or volcanic margin, see Tugend et al., 2018, and references therein), characterized by the presence of SDRs on the continentaloceanic transition domain (COT, Fig. 14). Volcanic margins have been related to high extension rates (spreading half rates in the order of $25-30 \mathrm{~mm} / \mathrm{yr}$, Lundin et al., 
2014). In the case of the South Atlantic, the northwards migration of rifting and ocean spreading took place in segments. Both conjugate margins, South American and African, present a strong segmentation as illustrated in Figs. 3 and 5 (Franke et al., 2007; Koopmann et al., 2014). Fracture zones (FZ) limit the different segments and are interpreted to be active at least since SDR emplacement (Franke et al., 2007; Franke, 2013). For reference on the segmentation of the South Atlantic margin, refer to Clemson et al. (1997), Franke et al. (2007), and Blaich et al. (2009). The origin and emplacement mechanisms of SDRs are out of the scono ui this study. Hereafter, in this study of the Southern South Atlantic Argentinear. II. argin, we follow the rationale presented by Geoffroy et al. (2005) and McDermu: et al. (2018) who differentiate between inner fault-bounded SDRs, and outer flaxu ${ }^{\circ}$ SDRs, that develop as part of the breakup process in a continuum from rifi, in 10 oceanic spreading.

In the seismic line presentec ir Fig. 14, the SDR wedges observed in the Argentinean margin are emplacea slong the COT. Further inboard, on continental crust, several half-grabens bo' 'nd 'r' by inboard-dipping faults are depicted. These depocenters are located aling ine outermost $200 \mathrm{~km}$ wide fringe of the continental crust domain along the Cu'nrado, Salado and Punta del Este basins, and have been associated with the Lirıy Cretaceous South Atlantic Rift (Lovecchio et al., 2018; see Fig. 15a).

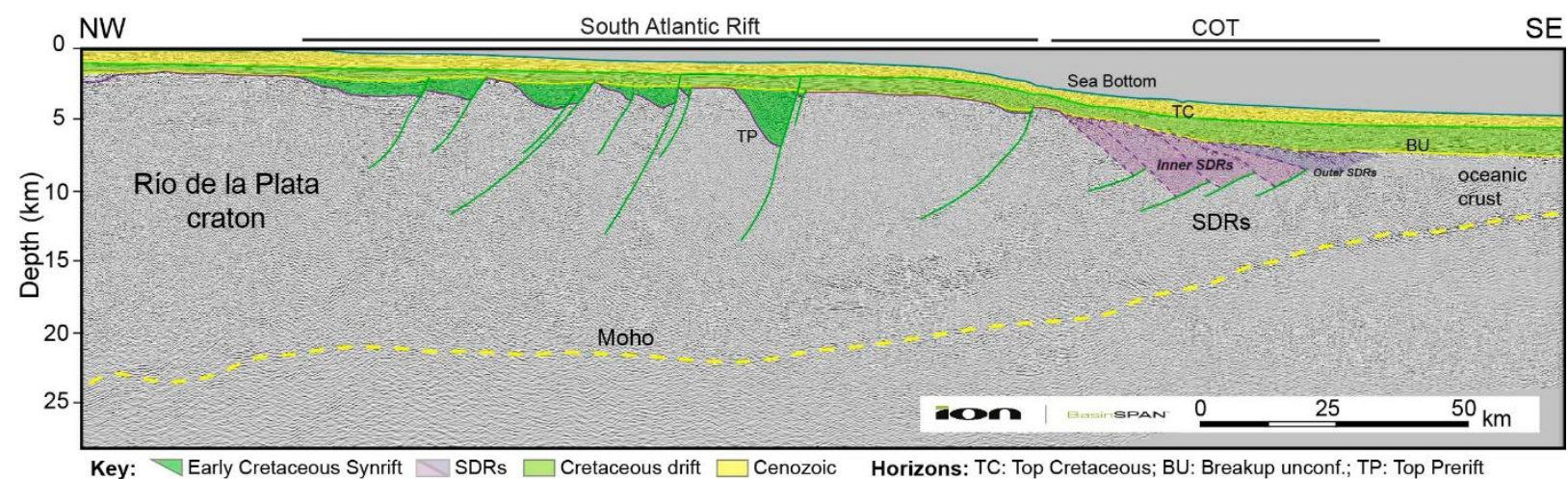

Fig. 14: Depth-converted dip seismic section of the northern Argentinean margin (southern Salado basin), between the Tandilia and Salado FZs. Location in Fig. 16. 

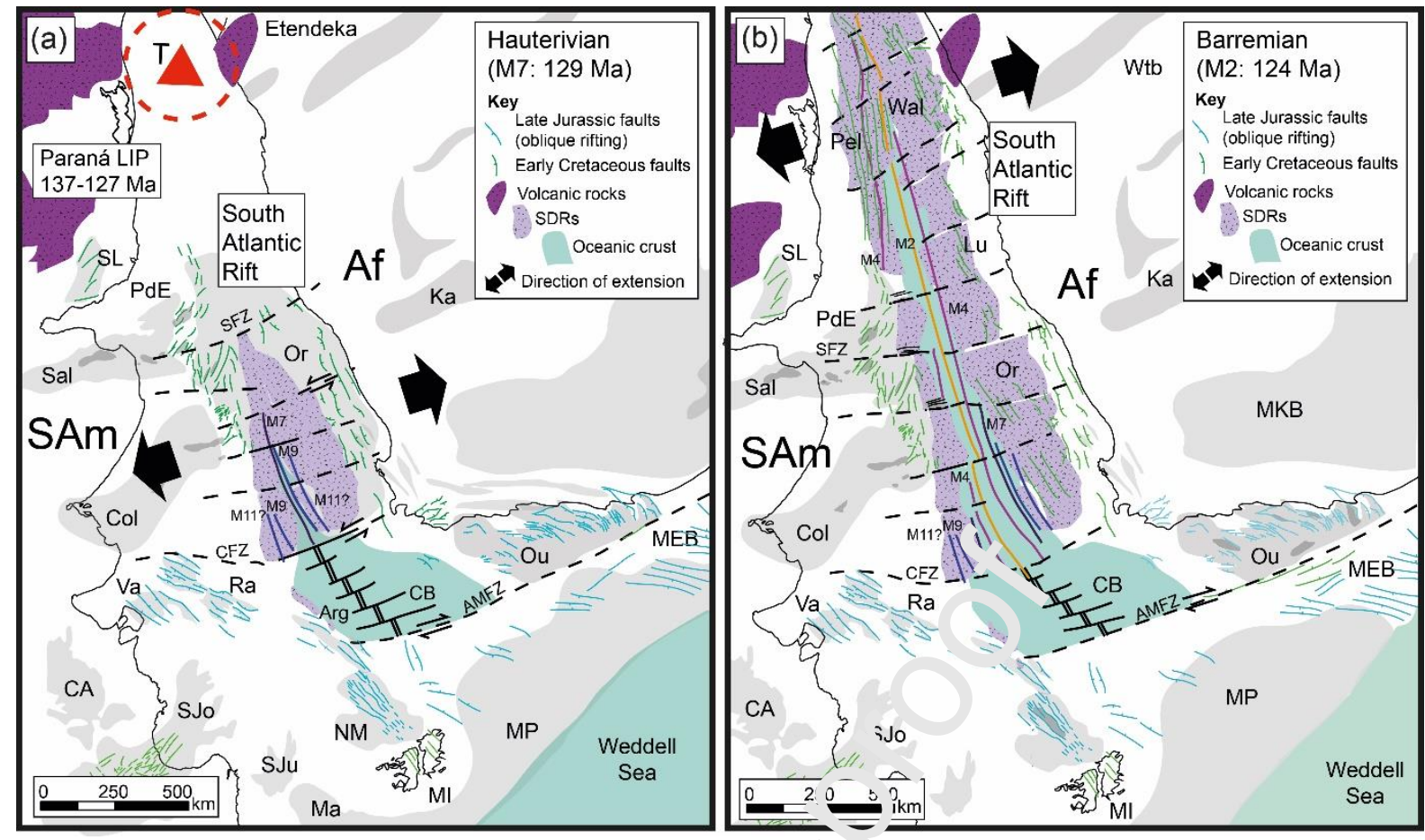

Fig. 15: Paleo-tectonic reconstructions of the Sout'، Atıantic Rift in the Early Cretaceous: a) Hauterivian: the southernmost Rawson/Vald :s - Outeniqua segment where breakup occurred in the Valanginian is in the drift ph: se; , lorth of the Colorado fracture zone (CFZ), SDRs are being emplaced along differer'، s gments during the breakup process. The South Atlantic rift has an approximate width $500 \mathrm{~km}$. Further North in the Pelotas/Walvis segment, the Paraná-Etendeka basa'ts are produced by the Tristan da Cunha (T) hotspot before onset of rifting; b) Barremian intı $ə$ rifting in the Pelotas/Walvis segment, while south the Salado fracture zone (SFZ) the cc ji gate margins are in the drift phase.

In the southernmosi styment of the southern South Atlantic however, it is interesting to note the ap, rarent absence of SDRs, below the Argentina and Cape conjugate basins (Fin. 3 and 5 respectively). This area with apparent absence (or proportionally less) SDRs is bracketed between the Agulhas-Malvinas (Falkland) FZ and the Colorado-Cape FZ (Fig. 15 and 16). The lack of SDRs in the southernmost segment of the South American margin has been interpreted, considering the vicinity of the AMFZ, as due to transform margin dynamics (Becker et al., 2012). Another characteristic to analyze is the difference in length (N-S) of the magma-poor segment on both sides of the South Atlantic (see Fig. 16): $380 \mathrm{~km}$ north of the AMFZ offshore South America (Franke et al., 2010) and approximately $460 \mathrm{~km}$ between the AMFZ 
and the first occurrence of SDRs offshore South Africa. This difference was interpreted by Koopmann et al. (2014) as a product of a pre-breakup extensional regime. Following Heine et al. (2013), they suggest that extension initiated in the Late Jurassic, with N-S extension that formed the Outeniqua and Rawson/Valdés basins and successively turned clockwise towards an E-W direction. Besides the SDRs, directly related to continental breakup, we present in Fig. 16 the Atlantic basins on the African margin and the main depocenter-bounding faults. Most of these structures are oriented parallel to the African present-day coastlin and the outer limit of the SDRs. In the Orange basin, some half-grabens devf iop $\geqslant a$ on continental crust, most of them bounded by seaward-dipping faults (liko iro AJ depocenter, Fig. 16; see Broad et al., 2012). On the South American corr, 'qate margin, Stica et al. (2014) presented a series of continentward-dip, ir. faults as bounding both synrift depocenters and SDR wedges. The n;. cure of the SDRs bounding surfaces, either SDR-bounding faults (sensu Stica t' al., 2014) or feeder dykes for the SDR volcanic layers (Quirk et al., 2014), remain, under debate. We propose that even if these SDRs bounding surfaces migint not behave as standard normal faults, their orientation is directly as: 'n'jated with the stress regime at the time of SDR emplacement and thi- parallel to other normal faults on continental crust (Figs. 14 and 15a).

The COT in the segments between the Colorado/Cape FZ and the Salado/Orange FZ is characterized by along-strike asymmetry in width of the SDR wedges (transect G-G' in Fig. 17). The COT on the Argentinean margin is narrower and decreases in width northward towards the Salado FZ, while on the African margin the COT is wider and underwent significant thinning (Blaich et al., 2011). 


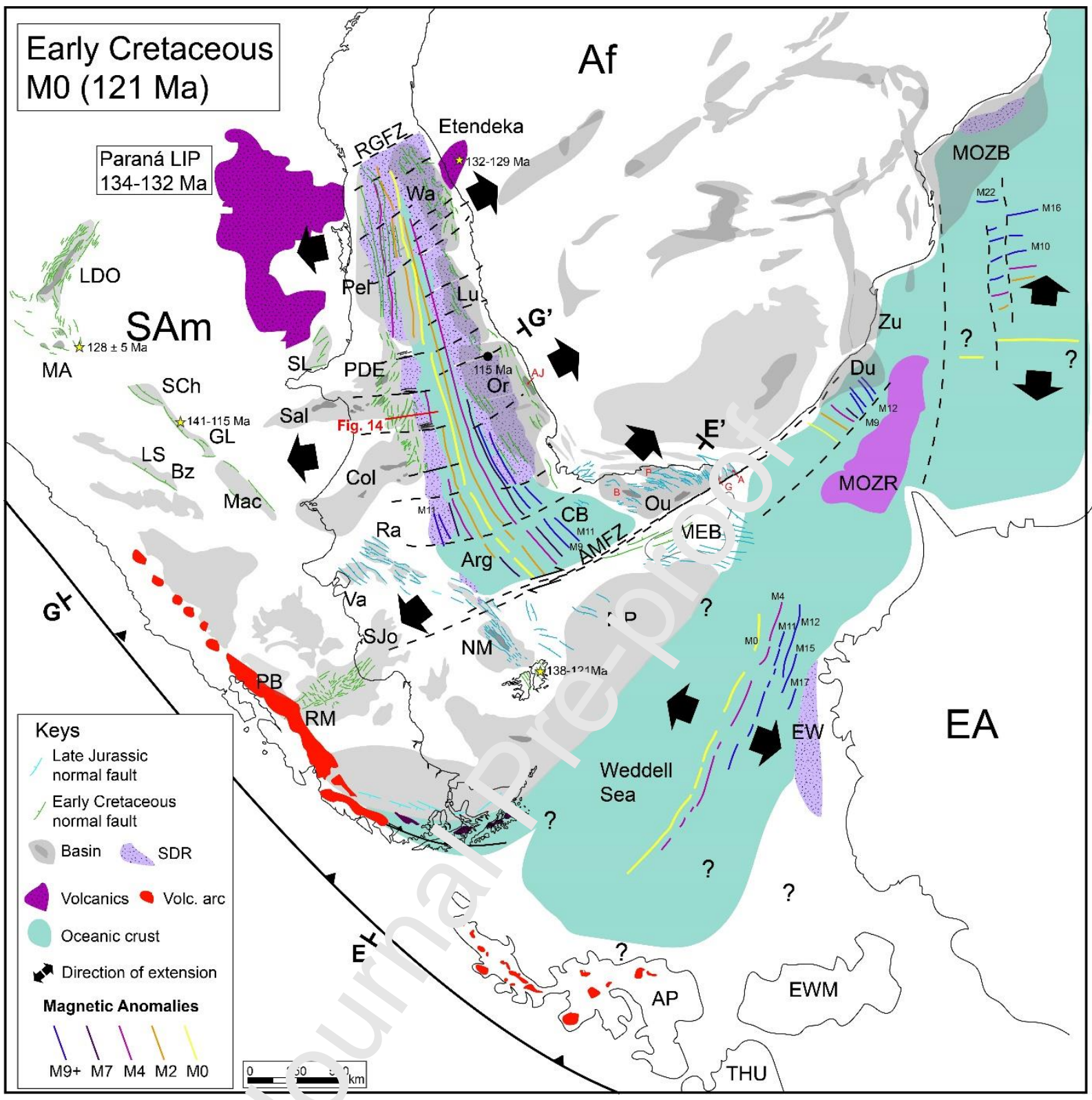

Fig. 16: Paleo-tectonic, cunstruction of SW Gondwana in the Early Cretaceous (at $121 \mathrm{Ma}$ ). The South Atlantic openir.g is presented at an evolved stage. South America-Africa fit after Blaich et al. (2011), Antarctica blocks and magnetic anomalies in the Weddell Sea area and Mozambique basin after König and Jokat (2006). Magnetic anomalies in the and Natal Valley after Goodlad et al. (1982). Antarctica continues to drift south. Wrenching along the AMFZ allows the opening of the South Atlantic Ocean since the Mid-Valanginian. SDRs are absent in the southernmost segment. Southwards, the North Malvinas (North Falkland) graben is an extension of the Atlantic rift (Becker et al., 2012). Faults in the North Malvinas (North Falkland) area after Lohr and Underhill (2015). Dykes in the Malvinas (Falkland) Islands yielded an Early Cretaceous age (Stone et al., 2008). Extension is recorded on both margins in a narrow rift on both sides of the present-day COTs. SDRs develop on the other segments norths of Rawson. South American basins: Punta del Este (PDE); Santa Lucía (SL), Pelotas (Pel). African basins: Outeniqua (Ou), Orange (Or, age from biostratigraphy in the Kudu well, Erlank et al., 1990), Luderitz (Lu) and Walvis (Wa). Ancient basement structures are extensionally reactivated producing the Macachín (Mac), Sierras Chicas (SCh, ages from 
Lagorio, 2008), Las Salinas (LS) and Beazley basins of San Luis, Metán-Alemanía (MA) and Lomas de Olmedo basins (LDO, age after Galliski and Viramonte, 1988). The ParanáEtendeka LIP extrudes during this period (Pinto et al., 2011). Structures and depocenters after Uliana et al. (1989), Ramos and Turic (1996), Gladczenko et al. (1997), Jungslager (1999), Franke et al. (2007), Starck (2011), Broad et al. (2012), Stica et al. (2014), Koopmann et al. (2014), Figari et al. (2015), Lohr and Underhill (2015), and Lovecchio et al. (2018).

Although the age of rifting onset in the southernmost South Atlantic segment is yet poorly constrained (as both conjugate margins remain underexplored with limited magnetic data, see Franke, 2007; Becker et al., 2012; : nopmann et al., 2014), we presume that E-W oriented rifting might have started 1 - the Berriasian-Valanginian. Breakup (onset of oceanic spreading) initiate- In the south possibly in the Valanginian. The unconformity between synrift ' a id II in the Outeniqua basin is dated mid-Valanginian (Jungslager, 1996) end has been related to strike-slip movement along the Agulhas-Malvina, (1 alkiand) FZ due to E-W extension (Broad et al., 2012). Breakup progressively advanced north (Rabinowitz and LaBreque, 1979; Nürnberg and Müller, 1991). Hei ıє $t:$ al.'s, 2013) plate kinematic model indicates a top Hauterivian age for tha initiation of normal oceanic crust accretion at the Colorado/South Orange segr :ent, and Aptian in the northern Pelotas/Walvis segment (Fig. 11;. Rifting :na s',ccessive breakup were thus strongly diachronous and evolved in individual zegments bounded by fracture zones, possibly inherited form the rifting stage.

Onshore Argentina, a series of aligned Cretaceous basins developed on the western edge of the Rio de la Plata craton (Fig. 16; e.g. Macachín, General Levalle, Sierras Chicas, etc.) and another trend to the west of that one (e.g. Las Salinas, Beazley, etc., Uliana et al., 1989). The Santa Lucia basin develops within the Rio de la Plata craton, possibly associated with strike-slip as suggested by Veroslavsky (1999). In the San Jorge Gulf basin, a Neocomian phase of extension is responsible 
for a series of depocenters across the basin and extending to the west into the Rio Senguerr, Rio Mayo, and Rio Guenguel sub-basins (RM in Fig. 16, lannizzotto et al., 2004; Mpodozis and Ramos, 2008). In northern Argentina, the three-branched NW Argentina basin opened at this stage (Fig. 16), with the N-S oriented Metán/Alemanía and Tres Cruces sub-basins, and the E-W directed Lomas de Olmedo sub-basin.

G Early Cretaceous: Barremian

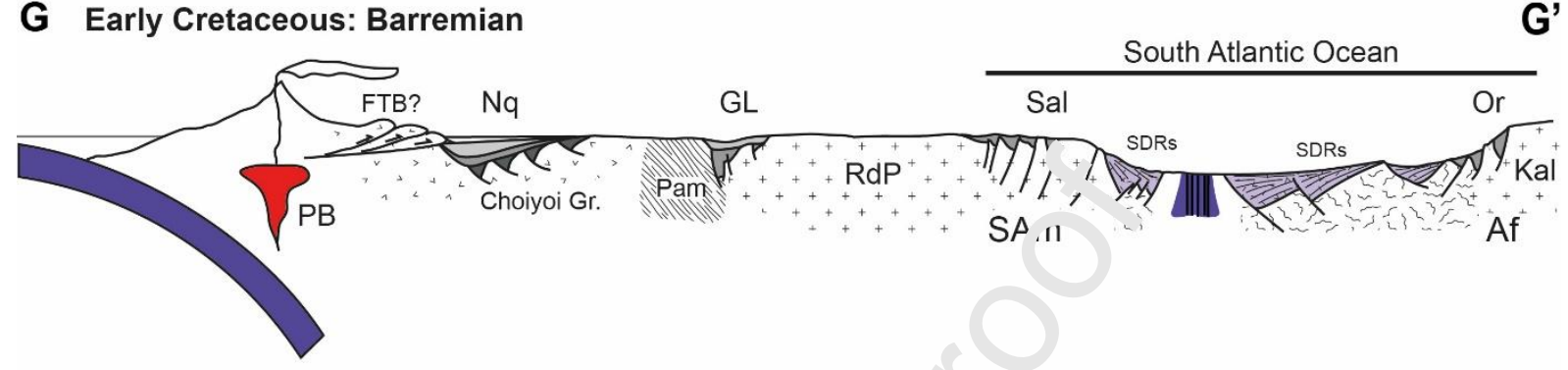

F Early Cretaceous: Valanginian/Hauterivian

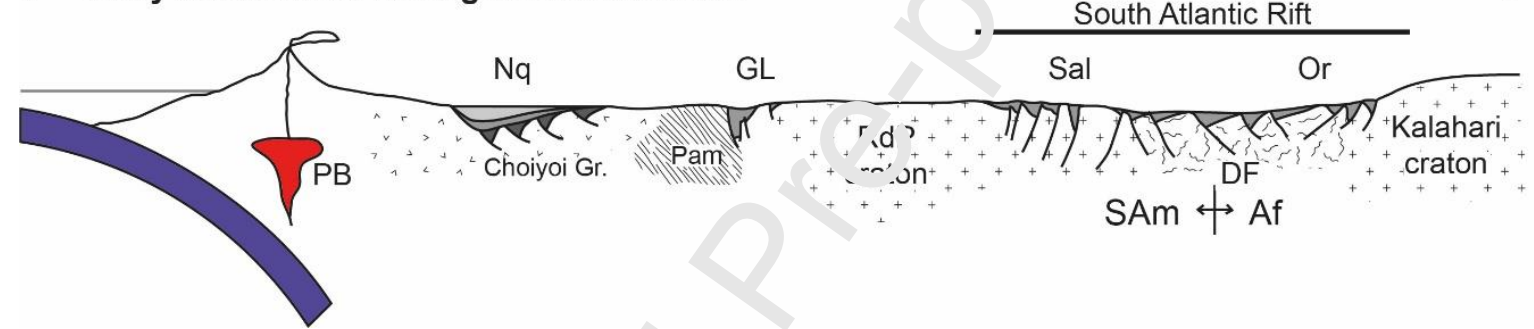

Fig. 17: Schematic cross sections of 'he SW Gondwana margin. F-F' is a transect for the Valanginian, with a magmatic arc $\mathrm{r}_{\mathrm{r}}{ }^{\circ}$ sented by the Patagonian Batholith. The General Levalle graben (GL) is depicted $/{ }_{-}^{4} e_{1}$ ! Vebster et al., 2004). Rifting in the South Atlantic Rift area (Fig. 15a) across the sol'i . .rn Salado basin (Fig. 14) and the Orange basin. Transect G-G' represents the same se tion in the Barremian, with SDRs emplacement along this segment in the Hauterivian, and breakup near the Hauterivian/Barremian boundary. Compression is interpret- $t \mathrm{t}$. the Neuquén basin retroarc $(\mathrm{Nq})$, possibly with development of a fold and thrust $b_{c}{ }^{1+}\left({ }^{\top} \mathrm{T}\right.$ ). See approximate location in the map in Fig. 15 and 16.

\section{DISCUSSION}

We have presented in our reconstructions a new model that portrays the occurrence and timing of Mesozoic rifting in SW Gondwana. Basement structural inheritance has played a key role in conditioning faults and development of depocenters throughout the Mesozoic. In the Triassic, for instance, the Cuyo basin developed on a suture between terranes accreted to the SW margin of Gondwana during the Paleozoic (Fig. 9; Ramos and Kay, 1991) that was extensionally 
reactivated in a retroarc setting when subjected to extension. In the Early Cretaceous, with E-W extension and the opening of the South Atlantic Ocean, a series of N-S oriented basins developed along the boundary between the Río de la Plata craton and the Pampia cratonic block (Fig. 17; e.g. Macachín, General Levalle, Sierras Chicas basins).

Regarding the mechanisms triggering rifting, we follow the rationale of Frizon de Lamotte et al. (2015) for Central Gondwana. Besides active rifting produced by plume impingement (Dewey and Burke, 1974), recent ctiki. ss suggest that in most cases rifting precedes volcanism (Buiter and Torsvit, ¿114; Peace et al., 2019) and subduction-related slab rollback instability is prosumed to be a major trigger of continent dispersal (Bercovici and Long, 2014). v'e have highlighted this effect for the Mesozoic evolution of SW Gondwana (F.g. 8; e.g. Cuyo, Bermejo, Neuquén

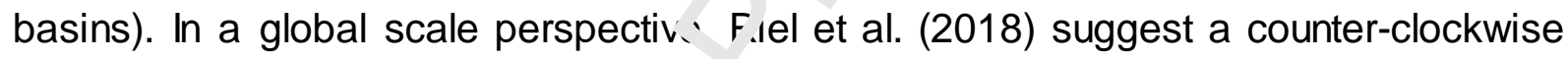
rotation of Pangea between $260 a_{1} \cdot 1230 \mathrm{Ma}$ as the cause for initiation of extension in the SW Gondwana margin. This i, also evident in the Antarctic Peninsula, with the trench-ward migration of the volvanic arc (Storey et al., 1992, 1996; Bastias et al., 2020). The presence of iriva ;ratonic rifts associated with the Karoo I event in central Gondwana (e.g. Sarm Iviaria, Waterberg) could also be related to far-field stresses associated with rifting in the Central Atlantic area occurring at that time (Figs. 1 and 7).

The Early Jurassic Karoo event (Karoo II) is an exception. Regional doming and volcanic activity prior to rifting confirm an active rifting mechanism (Frizon de Lamotte et al., 2015 and references therein) responsible for the opening of the Mozambique channel and breakup between Eastern and Western Gondwana (Storey, 1995; Fig. 1). We associate the Karoo event with the main phase of 
extension in the Colorado and Salado basins, offshore Argentina. Even if these basins would remain outside the area with plume-related volcanic activity, in their paleo-tectonic position (Fig. 10) they are aligned with the Karoo II depocenters in Africa and could be coeval with the Cuyo Group rifting in the Neuquén basin, largely associated with N-S extension in the Early Jurassic. The Colorado and Salado basins developed prior to the South Atlantic Rift (see Lovecchio et al., 2018 and references therein) and should be considered separately, especially when carrying out thermomechanical modelling of the South Atlantic breakup.

Out of the area of influence of the Karoo plu'ıt, towards the SW Gondwana margin, the Chon Aike magmatic province, $n n_{\epsilon}$ of the largest silicic igneous provinces known in the world (Kay et al., 130.1 played a major role, as it is intrinsically related to diachronous extensic: i., Patagonia, the Antarctic Peninsula and other Antarctic territories (Pank' ' Irs, et al., 2000). Rapela et al. (2005) propose the development of the Patagoniarı Subcordilleran Batholith volcanic arc, coeval with the Chon Aike MP, emplaced 'nc.' crustal extension. The southwestward migration and clockwise rotation c: the arc between the Early Jurassic Patagonian Subcordilleran Batholith $\mathrm{r}$ rition and the Late Jurassic-to-recent ( $\mathrm{N}-\mathrm{S}$ oriented) position along the "nues has been associated with differential slab rollback (Echaurren et al., 2017). Extension related to the Chon Aike MP has also been linked to the formation of the Cañadón Asfalto, Malvinas and Austral basins (Uliana et al., 1985; Lovecchio et al., 2019), to which we add, following Ramos et al. (2017), the South Rift of the North Malvinas (North Falkland) basin (Fig. 10).

Rifting in the Mozambique basin since the Early-Mid Jurassic (Karoo II rifting), and the successive opening of the Mozambique channel, could not have been accomplished without lateral slip along the proto-Weddell fracture zone that 
mechanically released Eastern from Western Gondwana (König and Jokat, 2006). This Jurassic deformation zone has been interpreted as the surface response to a slab-tear in the paleo-Pacific subduction zone, located between Patagonia and Antarctica (Lovecchio et al., 2019). The separation of Eastern from Western Gondwana both continents was a key milestone in the Gondwana dispersal process. Moreover, it allowed the acceleration of retro-arc extension in Western Gondwana, with rifting in the Malvinas and Austral basins, a process that culminated in the Late Jurassic with the opening the Rocas Verdes back-arc bacin (i ovecchio et al., 2019).

In the core of Western Gondwana, in a mo e intra-continental setting, Late Jurassic rifting in the Outeniqua and Rawson/Valais basins is presumed to have been oblique to the strike of the future South $A_{t+a},{ }^{+i c}$ COT, but rather parallel to the paleo-tectonic orientation of the northern F. ir'ss Verdes basin (Fig. 12). The area affected by the Outeniqua-Rawsor ${ }^{\prime} / a^{\prime}$ 'tés rifting is presumably the core of the Gondwanides orogen (Fig. 2 and $i$, an area subjected to compression in the Late Paleozoic with the collision of Dat:ronia. A possible analog to better understand the Rawson/Valdés - Outeniqui seyment could be the Gulf of Aden (see Leroy et al., 2010, 2012; Mohriak ana 'froy, 2013). Both systems seem to be related to oblique rifting and evolve thı'lyil a lateral third branch at almost $90^{\circ}$ (the South Atlantic Ocean, and the Red Sea respectively, Fig. 18). There are differences, however, between these two case studies. Regarding the rift-to-drift transition, in the Gulf of Aden, the system evolved to an oceanic basin as the stress regime remained oblique to the structural grain, and if extension persists in the Main Ethiopian Rift between Africa and Somalia, the system will end up split in three plates. In the case of the South Atlantic, the oblique rifting related to the Rawson-Valdés and Outeniqua basins was aborted, as the stress regime presumably changed from near N-S to almost E-W 
in a short period of time (Heine et al., 2013). The Agulhas-Malvinas (Falkland) lineation evolved, under the new stress regime, as a dextral shear zone at least since the Valanginian (Baby et al., 2018). The AMFZ could be another case of structural inheritance, as it could be the eastern extension of the suture related to the collision of a terrane comprising the Deseado Massif (see Fig. 2) against the Northern Patagonian Massif suggested by Pankhurst et al. (2006). Although there are differences regarding plume impingement in the Afar region, in our understanding the Gulf of Aden and the Afar triple junction could work as a y ?od analog for the early evolution of the Malvinas elbow (Fig. 18a), origir du' 9 the Argentina and Cape basins.

As has recently been suggested from rimerical modeling, oblique rifting seems to facilitate continental breakup, a? $:$ rrquires less force to reach the plastic

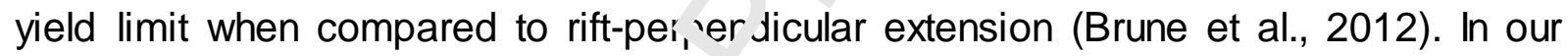
study case, we propose that a firsı , ?hase of oblique rifting in the Rawson/Valdés Outeniqua segment, might havn $k \curvearrowright n$ effective in thinning the lithosphere starting in the Late Jurassic (Fig. 13, ransect D-D'), where we interpret a single east-dipping detachment (following Ra.nrs, 1996). In the Early Cretaceous, lithosphere would have already been $u$ :nıed in the southernmost segment of the South Atlantic and when subjected to E-W extension, was the first segment to break up, without large magmatic volumes forming SDRs (Fig. 13, transect E-E'). The southernmost segment behaves, in our opinion and until new data are available, as a magma-poor, abrupt margin (Fig. 15a).

Breakup along the South Atlantic Rift occurred in segments delimited by fracture zones (FZ). Mechanics of rift propagation across the different segments have been postulated by several authors, notably Franke et al. (2007), Franke (2013), 
Blaich et al. (2013), and Koopmann et al. (2014). Regarding the E-W oriented extension since at least the Mid-Valanginian, we agree with the model presented by Blaich et al. (2011) who introduced a two-phase breakup process, with first a continental rifting phase (crustal thinning) forming a $500-\mathrm{km}$ wide Atlantic rift system (Fig. 15 and 17) followed by the breakup phase with SDR emplacement and successive oceanic spreading (Lovecchio et al., 2018). Both phases could have taken place as part of a continuous process. The origin of that E-W extension could also be related to retroarc dynamics produced by chancos in the subduction regime (notably the depth reached by the subducting plate ar. the size of the convection cell) as recently postulated by dal Zilio et al. $(2 \cap 1 \imath)$, and the occurrence of SDRs would then be produced by interactions of an a're idy installed rift system (the South Atlantic Rift) with a mantle plume (Tristán dá :':aha, Fig. 15a).

In the Hauterivian, oceanic sf: $:$ sing had already started in the southernmost Rawson/Valdés - Outeniqua segme. ${ }^{\dagger+}$ (probably since the mid Valanginian, Fig. 15a). The Colorado FZ is a major fa $\mathrm{a}^{\text {" }} \mathrm{e}$ a this stage, accommodating oceanic crust accretion to the south, and "ontınental rifting and SDR emplacement to the north. In the Colorado-Orange sentrar.t, rifting is restricted to a $500 \mathrm{~km}$ wide rift system, while the areas affected $L \because$ ulder fossilized rifting stages (Late Triassic to Early-Mid Jurassic) remain in a thermal sag phase (Lovecchio et al., 2018). We believe this is an important observation to be considered in future thermo-mechanical modeling of the South Atlantic breakup at the Colorado segment: the older rifts forming the Central and Eastern Colorado depocenters should not be modelled as part of the same Early Cretaceous South Atlantic rifting. 

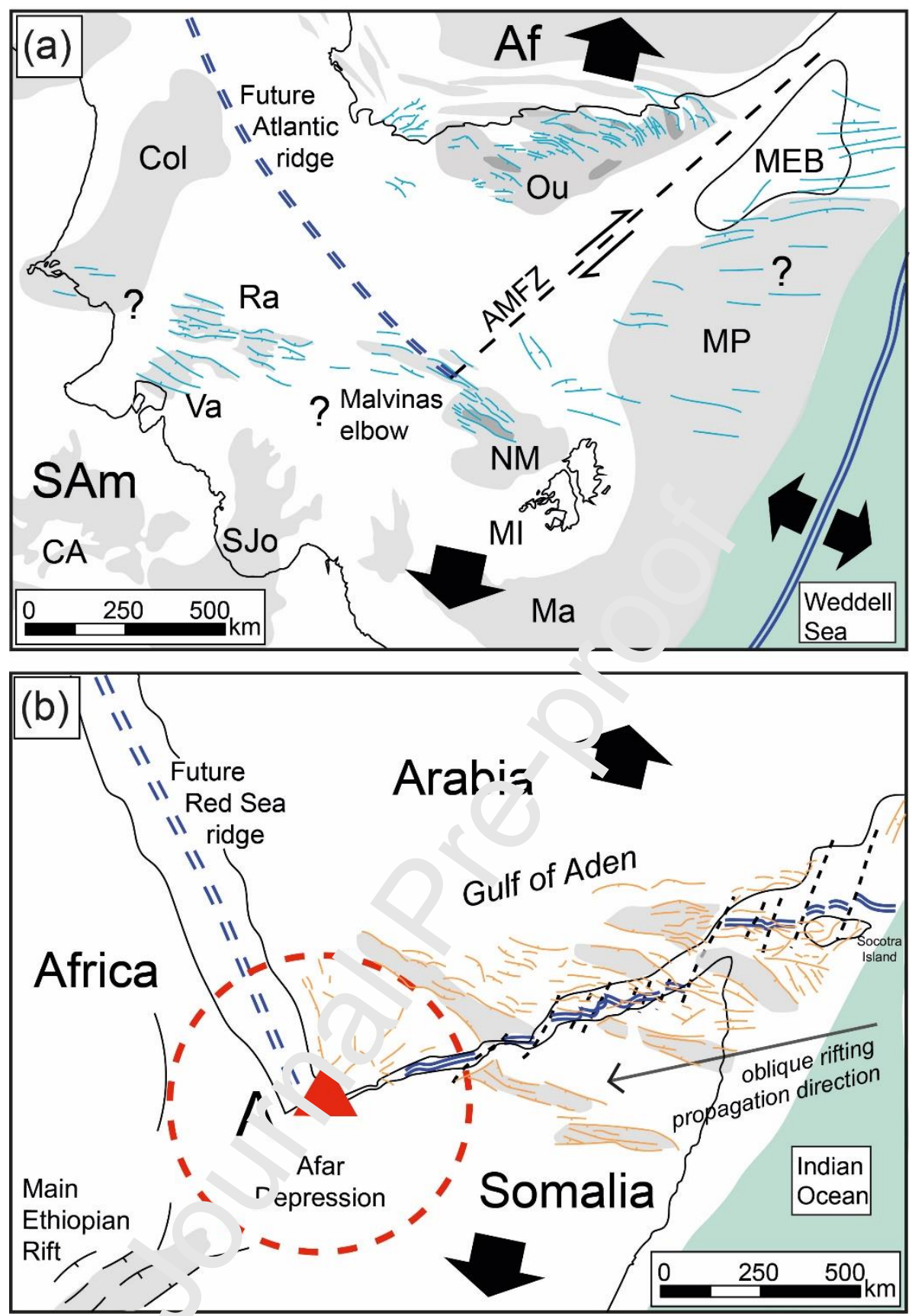

Fig. 18: Comparison of a) Late Jurassic oblique rifting in the southern South Atlantic area; and b) Cenozoic oblique rifting in the Gulf of Aden (after Leroy et al., 2012 and Mohriak and Leroy, 2013).

The South Atlantic Rift followed basement weakness zones, formed in the Neoproterozoic Brasiliano-Panafrican Orogeny. These weakness zones could have been either sutures (Hartnady et al., 1985) or, as recently suggested by Will and Frimmel (2018), the long axes of Neoproterozoic back-arc basins (the Marmora basin, Namibia). We believe that basement inheritance certainly played an important 
role, but what was key for the orientation of the South Atlantic rift was the rotation of the stress regime in the Early Cretaceous to a more orthogonal position with respect to this basement structural fabric. This configuration would have allowed the rapid propagation of rifting following precursor weakness zones, north of the already rifted Rawson-Valdés/Outeniqua segment. Wrenching along the AMFZ was necessary to accommodate extension to the north of it and allow continent separation. Early Cretaceous rifting is present, however, south of the AMFZ. The North Branch of the

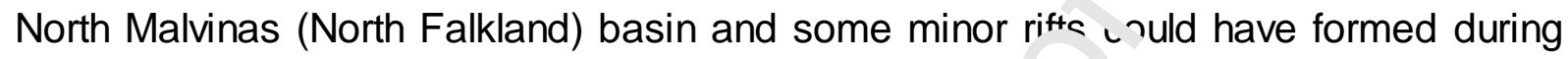
the Late Jurassic, but they also seem to connect to $t^{\prime} i e$ South Atlantic Rift to the north (Becker et al., 2012; Lohr and Underhill, 2015) Probably due to plate's relative rotations and the presence of a lithospheric dis $s 0_{1}$ inuity, breakup favored wrenching along the AMFZ instead of continuinc irn jagation to the south (through the nowadays aborted North Malvinas $-\Lambda \sim r t r$. Falkland- graben).

\section{CONCLUSIONS}

The opening of the inutr Atlantic in the Early Cretaceous was only the final stage of the complex rift1, I history of SW Gondwana. Evidence for intracontinental rifts is present in Afric ? and South America in the Triassic (Karoo I), synchronous with retroarc depocenters in SW Gondwana margin (Cuyo, Bermejo, Precuyano of Neuquén, Deseado and Malvinas basins) that are clearly related to subduction dynamics (passive rifting).

In the Early Jurassic, rifting in Eastern Africa was triggered by the impact of the Karoo plume, which produced the formation of a network of Karoo II depocenters in Africa (active rifting). The Colorado and Salado basins in the Argentinean shelf formed at this stage, together with the Cuyano cycle of the Neuquén basin. Rifting in 
East Africa ultimately produced the breakup of Eastern from Western Gondwana in the Middle Jurassic. In Patagonia, the Chon Aike silicic magmatic province was emplaced at this time, in a retroarc setting behind the Subcordilleran Batholith arc. Retroarc extension, due to differential slab rollback is responsible for the formation of the Cañadón Asfalto, Austral and Malvinas basins, and possibly the southern rift of the North Malvinas (Falkland) basin and was possibly triggered by a slab tear between Patagonia and Antarctica (Lovecchio et al., 2019).

Retro-arc extension continued and, subsequent slab steepening produced in

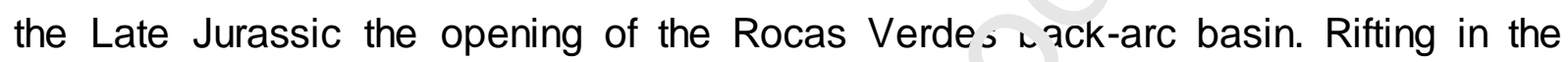
Outeniqua and Rawson/Valdés basins took place ai this stage, in an oblique setting to the future South Atlantic COT. The Late Jurassis rifting affected the orogenic core of the Gondwanides orogen and is precl's: $r$ \% South Atlantic opening. Subduction dynamics is the main process cor." "ol'.ng extension in the SW Gondwana region during the Mesozoic.

The South Atlantic Rift no. cibly took advantage of crustal weakness zones (Precambrian mobile belts) : it is related to a rotation of the stress field to a presentday near E-W direction. R.fting occurred diachronically from south to north and started during or beive the Valanginian. The southernmost segment, between the Agulhas-Malvinas (Falkland) fracture zone and the Colorado-Cape, had already been affected by crustal thinning during the Late Jurassic oblique rifting. This could explain the lack of SDRs in this segment, which was the core of the Late Paleozoic Gondwnides orogen later on subjected to multiple phases of extension. North of the Colorado-Cape fracture zones, rifting and SDR emplacement took place in segments bounded by fracture zones. SDR emplacement was asymmetrical on both margins and eventually oceanic crust inception propagated diachronically along the margin, 
between Hauterivian and Aptian times. The opening of the South Atlantic is another case of passive rifting and recent models suggest that subduction-related mechanisms linked to deep subduction could trigger extension as far as $3,500 \mathrm{~km}$ away from the trench (dal Zilio et al. 2018).

The nucleus where the South Atlantic Ocean was initiated, corresponds to the place where the main extensional phases identified were locally superimposed throughout the Mesozoic. Thus, maximum crustal extension present in the area, favored breakup and the development of the magma-ponr = רuthernmost segment of the southern South Atlantic.

\section{ACKNOWLEDGEMENTS}

This contribution is part of J.P. L Junrnio's Ph.D. dissertation. The authors thank YPF S.A. for making availu hle the database for this study and for the continuous support during the rese $i$ rch. ION Geophysical kindly granted permission for the publication of the seismic $\because$,ction presented in Fig. 12. The two anonymous reviewers are acknowledge $i$ for their contributions towards the improvement of the manuscript.

\section{REFERENCES}

Abreu, V. dos S. (1998). Geologic evolution of conjugate volcanic pasive margins. Pelotas basin (Brazil) and Offshore Namibia (Africa); Implicationsforglobalsea-level changes. Rice University.

Adie, R. J. (1952). Representatives of the Gondwana System in the Falkland Islands. Symposium Sur Le Series de Gondwana, 19th International Geological Congress, 385-392.

Amante, C., \& Eakins, B. W. (2009). ETOPO1 1 Arc-Minute Global Relief Model: Procedures, Data Sources and Analysis. NOAA Technical Memorandum NESDIS NGDC-24.

Autin, J., Scheck-Wenderoth, M., Loegering, M.J., Anka, Z., Vallejo, E., Rodriguez, J.F., Dominguez, F., Marchal, D., Reichert, C., di Primio, R., Götze, H.J. (2013). Colorado Basin 3D structure and evolution, Argentine passive margin. Tectonophysics 604, 264-279. https://doi.org/10.1016/j.tecto.2013.05.019 
Baby, G., Guillocheau, F., Boulogne, C., Robin, C., \& Dall, M. (2018). Tectonophysics Uplift history of a transform continental margin revealed by the stratigraphic record: The case of the Agulhas transform margin along the Southern African Plateau DOME. Tectonophysics, 731-732(March), 104-130. https://doi.org/10.1016/j.tecto.2018.03.014

Barker, P. F. (1999). Evidence for a volcanic rifted margin and oceanic crustal structure for the Falkland Plateau Basin. Journal of the Geological Society, 156, 889-900. https://doi.org/10.1144/gsjgs.156.5.0889

Barredo, S., Chemale, F., Marsicano, C., Ávila, J. N., Ottone, E. G., \& Ramos, V. A. (2012). Tectonosequence stratigraphy and U-Pb zircon ages of the Rincón Blanco Depocenter, northern Cuyo Rift, Argentina. Gondwana Research, 21(2-3), 624-636. https://doi.org/10.1016/j.gr.2011.05.016

Basei, M.A.S., Frimmel, H.E., Campos Neto, M.D.C, Ganade de Arac io, C.E., Araujo de Castro, N. and Passarelli, C.R., 2018. The Tectonic History of the Southern r. ramastor Ocean Based on a Correlation of the Kaoko and Dom Feliciano Belts. In Sie esn und et al. (eds.), Geology of Southwest Gondwana, Springer Nature Regional Geology P - it w.., https://doi.org/10.1007/9783-319-68920-3_3

Bastias, J., Spikings, R., Ulianov, A., Burton-Johnson, A. c . '尹ı ıdia, M., Baumgartner, L., Hervé, F., Bouvier, A.S. (2020). The Gondwanan margin in v'sst Antarctica: Insights from Late Triassic magmatism of the Antactic Peninsula. Conavana Research, v. 81, p. 1-20. https://doi.org/10.1016/j.gr.2019.10.018

Bechis, F., Cristallini, E. O., Giambiagi, L. B. ․ qur `ky, D. L., Guzmán, C. G., \& García, V. H. (2014). Transtensional tectonics induced by o' 'ia' e reactivation of previous lithospheric anisotropies during the Late Triassic to Early Jurassic -ifting in the Neuquén basin: Insights from analog models. Journal of Geodynamics, 7s, 1-17. https://doi.org/10.1016/j.jog.2014.04.010

Becker, K., Franke, D., Schnabel, M., Sct re ckenberger, B., Heyde, I., \& Krawczyk, C. M. (2012). The crustal structure of the south $\pm r n$.'rgentine margin. Geophysical Journal International, 189(3), 1483-1504. https://doi.org/ 10..111/j.1365-246X.2012.05445.x

Bellahsen, N., Husson, L., Autir. J., Leroy, S., \& d'Acremont, E. (2013). The effect of thermal weakening and buoy -ny s. rces on rift localization: Field evidences from the Gulf of Aden oblique rift ng. Tectonophysics, 607(NOVEMBER), https://doi.org/10.1し'6/j.tecto.2013.05.042

Bellosi, E. S., \& Jalfin, G. A. (1989). Cuencas Neopaleozoicas de la Patagonia Extraandina e Islas Malvinas. In Cuencas Sedimentarias Argentinas (pp. 379-393).

Bercovici, D., \& Long, M. D. (2014). Slab rollback instability and supercontinent dispersal, 1-8. https://doi.org/10.1002/2014GL061251.Abstract

Biddle, K. T., Snavely, P. D. I., \& Uliana, M. A. (1996). Plateau de Malvinas. In V. A. Ramos \& M. A. Turic (Eds.), Geología y Recursos Naturales de la Plataforma Continental Argentina1 (pp. 225252). Asociación Geológica Argentina; Instituto Argentino del Petróleo.

Blaich, O. A., Faleide, J. I., \& Tsikalas, F. (2011). Crustal breakup and continent-ocean transition at South Atlantic conjugate margins. Journal of Geophysical Research: Solid Earth, 116(1), 1-38. https://doi.org/10.1029/2010JB007686

Blaich, O. A., Faleide, J. I., Tsikalas, F., Franke, D., \& León, E. (2009). Crustal-scale architecture and segmentation of the Argentine margin and its conjugate off South Africa. Geophysical Journal 
International, 178(1), 85-105. https://doi.org/10.1111/j.1365-246X.2009.04171.x

Blaich, O. A., Faleide, J. I., Tsikalas, F., Gordon, A. C., \& Mohriak, W. U. (2013). Crustal-scale architecture and segmentation of the South Atlantic volcanic margin. In W. U. Mohriak, A. L. Danforth, P. J. Post, D. E. Brown, G. C. Tari, M. Nemcok, \& S. T. Sinha (Eds.) (pp. 167-183). Geological Society Special Publication 369.

Brandsen, P. J. E., Burges, P., Durham, M. J., \& Hall, J. G. (1999). Evidence for multi-phase rifting in the North Falklands Basin. In N. R. Cameron, R. H. Bate, \& V. S. Clure (Eds.), The Oil and Gas Habitats of the South Atlantic (pp. 425-442). Geological Society of London Special Publications 153.

Broad, D. S., Jungslager, E. H. A., McLachlan, I. R., Roux, J., \& Van der Spuy, D. (2012). South Africa's offshore Mesozoic basins. Regional Geology and Tectonics. https://doi.org/10.1016/B978-0444-56357-6.00014-7

Brune, S., Popov, A. A., \& Sobolev, S. V. (2012). Modeling suggests cha oblique extension facilitates rifting and continental break-up. Journal of Geophysiru.' Desearch: Solid Earth, 117(8). https://doi.org/10.1029/2011JB008860

Buiter, S. J. H., \& Torsvik, T. H. (2014). A review of Wilsm C, fle plate margins: A role for mantle plumes in continental break-up along suture? $G$ Jndwana Research, 26(2), 627-653. https://doi.org/10.1016/j.gr.2014.02.007

Calderon, M., Herve, F., Fuentes, F., Fosdick, ! -., ؟ epulveda, F., \& Galaz, G. (2016). Tectonic Evolution of Paleozoic and Mesozoic Arrecn Metamorphic Complexes and the Rocas Verdes Ophiolites in Southern Patagonia. '। N. C. Ghiglione (Ed.), Geodynamic Evolution of the Southernmost Andes (pp. 7-36). 'witzerland: Springer International Publishing. https://doi.org/10.1007/978-3-319-?9727-6

Calderón, M., Prades, C. F., Hervé, F., A'/e .daño, V., Fanning, M., Massonne, H. J., ... Simonetti, A. (2013). Petrological vestiges $C$. ' he idte Jurassic-Early Cretaceous transition from rift to backarc basin in southernmost $\pi_{1} \cdot{ }^{1}$ e: New age and geochemical data from the Capitán Aracena, Carlos III, and Tortuga sphiolitic complexes. Geochemical Journal, 47, 201-217. https://doi.org/10.2343/geo, hemj.2.0235

Caminos, R. (1999). Geol gria Argentina. Servicio Geologico Minero Argentino. Retrieved from http://scholar.goog. ' cum/scholar?hl=en\&btnG=Search\&q=intitle:Geologia+argentina\#2

Carbone, O., Franzese, J., Limeres, M., Delpino, D., Martinez, R. 2011. El ciclo Precuyano (Triásico Tardío-Jurásico Temprano) en la Cuenca Neuquina. In: Leanza, H.A., Arregui, C., Carbone, O., Danieli, J.C., Vallés, J.M. Geología y Recursos Minerales de la Provincia de Neuquén. XVIII Congreso Geológico Argentino. Neuquén, 2-6 May 2011, p. 63-76

Cartwright, J., Swart, R., \& Corner, B. (2012). Conjugate margins of the South Atlantic: NamibiaPelotas. Regional Geology and Tectonics. https://doi.org/10.1016/B978-0-444-56357-6.00005-6

Catuneanu, O., Wopfner, H., Eriksson, P. G., Cairncross, B., Rubidge, B. S., Smith, R. M. H., \& Hancox, P. J. (2005). The Karoo basins of south-central Africa. Journal of African Earth Sciences, 43(1-3), 211-253. https://doi.org/10.1016/j.jafrearsci.2005.07.007

Charrier, R. 1979. El Triasico de Chile y regiones adyacentes de Argentina: una reconstruccio'n paleogeográfica y paleoclimática. Comunicaciones, v. 26, p. 1-37.

Charrier, R., Ramos, V.A., Tapia, F., Sagripanti, L. (2014). Tectono-stratigraphic evolution of the 
Andean Orogen between 31 and $37^{\circ} \mathrm{S}$ (Chile and Western Argentina). In: Sepúlveda, S.A., Giambiagi, L.B., Moreiras, S.M., Pinto, L., Tunik, M., Hoke, G.D., Farías, M. (eds.). Geodynamic Processes in the Andes of Central Chile and Argentina. Geological Society, London, Special Publications, v. 399,

Chebli, G. A., Cortiñas, J. S., Spalletti, L. A., Legarreta, L., Vallejo, E. (Eds.). (2005). Frontera Exploratoria de la Argentina. Instituto Argentino de Petróleo y Gas (IAPG) 335 pp.

Chebli, G., Spalletti, L. A. (1989). Cuencas Sedimentarias Argentinas. (First). San Miguel de Tucuman: Universidad Nacional de Tucumán.

Chemale, F., Ramos, V. A., Naipauer, M., Girelli, T. J., \& Vargas, M. (2018). Age of basement rocks from the Maurice Ewing Bank and the Falkland/Malvinas Plateau. Precambrian Research, 314(May), 28-40. https://doi.org/10.1016/j.precamres.2018.05.026

Clavijo, R. (1986). Estratigrafia del cretacico inferior en el sector ou ' Jental de la cuenca Golfo San Jorge. Boletin de Informaciones Petroleras, (9), 15-32.

Clemson, J., Cartwright, J., \& Booth, J. (1997). Structural segme itai on and the influence of basement structure on the Namibian passive margin. Journal of the Eeological Society, 154(3), 477-482. https://doi.org/10.1144/gsjgs.154.3.0477

Clemson, J., Cartwright, J., \& Swart, R. (1999). The Namib Ift: a rift system of possible Karoo age, offshore Namibia. Geological So in'y, London, Special Publications. https://doi.org/10.1144/GSL.SP.1999.153.01 2:

Colombi, C. E., Santi-Malnis, P., Correa, G. A , Mé tínez, R. N., Fernandez, E., Abelín, D., ... Drovandi, J. (2015). La Formación Balde de Leyes, u. . nueva unidad estratigráfica de la Cuenca Triásica de Marayes-El Carrizal, San Juan. Revi-'a de La Asociacion Geologica Argentina, 72(4), 445-455.

Continanzia, J., Manceda, R., Covello 'e - \& Gavarrino, A. (2011). Cuencas de Rawson y Valdés: Síntesis del conocimiento explr : atc-i J-Visión Actual. In E. Kozlowsky, L. Legarreta, A. Boll, \& P. Marshall (Eds.), Simposio Cu ncas Argentinas Visión Actual: VIII Congreso de Exploración y Desarrollo de Hidrocarburos 'pp. 47-63). Instituto Argentino del Petróleo y del Gas.

Cuneo, R., Ramezani, J., Scassc, R., Pol, D., Escapa, I., Zavattieri, A. M., \& Bowring, S. A. (2013). Highprecision U-Pb geoc'iror. logy and a new chronostratigraphy for the Canadon Asfalto Basin, Chubut, central $\mathrm{Pa}$ จ $\mathrm{g}_{\mathrm{L}}$ : $\mathrm{d}$ : Implications for terrestrial faunal and floral evolution in Jurassic. Gondwana Research, . 4(3-4), 1267-1275. https://doi.org/10.1016/j.gr.2013.01.010

Curtis, M. (2001). Tectonic history of the Ellsworth Mountains, West Antarctica: Reconciling a Gondwana enigma. Geological Society of America Bulletin, 113(7), 939-958.

D’Elia, L., Bilmes, A., Franzese, J. R., Veiga, G. D., Hernández, M., \& Muravchik, M. (2015). Early evolution of the southern margin of the Neuquén Basin, Argentina: Tectono-stratigraphic implications for rift evolution and exploration of hydrocarbon plays. Journal of South American Earth Sciences, 64, 42-57. https://doi.org/10.1016/j.jsames.2015.09.004

Dalziel, I. W. D., Lawver, L. A., Norton, I. O., \& Gahagan, L. M. (2013). The Scotia Arc: Genesis, Evolution, Global Significance. Annual Review of Earth and Planetary Sciences, 41(1), 767-793. https://doi.org/10.1146/annurev-earth-050212-124155

Dal Zilio, L., Faccenda, M., Capitanio, F. (2018). The role of deep subduction in supercontinent breakup. Tectonophysics, v. 746, p. 312-324. https://doi.org/10.1016/j.tecto.2017.03.00 
Davison, I., \& Steel, I. (2018). Geology and hydrocarbon potential of the East African continental margin: a review. Petroleum Geoscience, 24(1), 57-91. https://doi.org/10.1144/petgeo2017028

de Elorriaga, E. E. (2010). Evaluacion de los depocentros de la cuenca de Macachin, provincias de La Pampa y Buenos Aires. Universidad Nacional del Sur.

De Swardt, A. M. J., \& McLachlan, I. R. (1982). Petroleum exploration in the South African offshore: the geological framework and hydrocarbon potential. In H. W. Glen (Ed.), Proceedings of the 12th CMMI Congress (pp. 147-161). Johannesburg,: South Africa Inst. Min. Metall.

Del Rey, A., Deckart, K., Planavsky, N., Arriagada, C., Martínez, C. (2019). Tectonic evolution of the southwestern margin of Pangea and its global implications: Evidence from the mid PermianTriassic magmatism along the Chilean-Argentine border. Gondwana Research. https://doi.org/10.1016/j.gr.2019.05.007

De Wit, M. J., \& Ransome, I. G. D. (1992). Inversion tectonics it l, e Cape Fold Belt, Karoo and Cretaceous basins of Southern Africa. (M. J. De Wit \& I. G. D $k_{2}$ nc Jme, Eds.), Proceedings of the Conference on Inversion Tectonics of the Cape Fold Belt. lod $\epsilon$ dam: Balkema.

Dewey, J. F. (State U. of new Y. at A., \& Burke, K. (Statr 'I. . f new Y. at A. (1974). Hot Spots and Continental Break-up : Implications for Collisionai Irog „ny. Geology, 2, 57-60.

Dimieri, L., Delpino, S., Turienzo, M., 2005. Estructur. ¿'? las Sierras Australes de Buenos Aires. In: de Barrio, R.E., Etcheverry, R.O., Caballe, M.F., L, nk as, E. (Eds.), Geología y Recursos Minerales de la Provincia de Buenos Aires, XVI Cor_re 7 Geologico Argentino, pp. 101-118. La Plata.

Dingle, R. V. (1973). Mesozoic Pal eogeograpr, of the Southern Cape, South Africa. Palaeogeography, Palaeoclimatology, Palaeoecology, 13, 203-213.

Diraison, M., Cobbold, P. R., Gapais, D, 'nssello, E. A., \& Corre, C. Le. (2000). Cenozoic crustal thickening, wrenching and rifti $r$ it tie foothills of the southernmost Andes. Tectonophysics, 316, 91-119.

Dominguez, F., Marchal, D., Sis 'smı undi, M., Espejón, C., \& Vallejo, E. (2011). Caracterizacion de Dominios Estructuralest 'nfl' ıencia de Estructuras Preexistentes en Hemigrábenes de Rift en el Sector Centro-Norte de 'a Plataforma Contiental Argentina, in: XVIII Congreso Geologico Argentino, $2 \mathrm{p}$.

Du Toit, A.L., 1927. A geciugical comparison of South America with South Africa, 381. Publications Carnegie Institute, pp. 1-157.

Du Toit, A.L., 1937. Our Wandering Continents. Oliver and Boyd, London, 366 pp.

du Toit, A. (1979). The Mesozoic history of the Agul has Bank in terms of the plate-tectonic theory. In A. M. Anderson \& W. J. van Biljon (Eds.), Some sedimentary basins and associated ore deposits of South Africa (pp. 197-203). Johannesburg, South Africa: Special Publication of the Geological Society of South Africa 6.

Duncan, R. A., Hooper, P. R., Rehacek, J., Marsh, J. S., \& Duncan, A. R. (1997). The timing and duration of the Karoo igneous event, southern Gondwana, v. 102, p. 127-138.

Eagles, G. (2016). Plate kinematics of the Rocas Verdes Basin and Patagonian orocline. Gondwana Research, v. 37, p. 98-109.

Eagles, G. \& Vaughan, P.M. (2009). Gondwana breakup and plate kinematics: Business as usual. 
Geophysical Research Letters, v. 36, L103302, doi:10.1029/2009GL037552, 4 pp.

Echaurren, A., Oliveros, V., Folguera, A., Ibarra, F., Creixell, C., \& Lucassen, F. (2017). Early Andean tectonomagmaticstages in North Patagonia: Insights from field and geochemical data. Journal of the Geological Society, (February). https://doi.org/10.1144/jgs2016-087

Elliot, D.H. \& Fleming, T.H. (2000). Weddell triple junction: the principal focus of Ferrar and Karoo magmatism during initial breakup of Gondwana. Geology, v. 28, p. 539-542.

Erlank, A. J., Roex, A. P., Harris, C., Miller, R. M., \& McLachlan, I. (1990). Preliminary note on the geochemistry of basalt samples from the Kudu boreholes. Commun. Geol. Surv. Namib, 6, 6365.

Espinoza, M., Montecino, D., Oliveros, V., Astudillo, N., Vazquez, P., Reyes, R., ... Martínez, A. (2018). The synrift phase of the early Domeyko Basin (Triassic, north $r$ rn Chile): Sedimentary, volcanic and tectonic interplay in the evolution of an ancient subciution-related rift basin. Basin Research, (July). https://doi.org/10.1111/bre.12305

Ewing, J. I., Ludwig, W. J., Ewing, M., \& Eitreim, S. L. (1971). St uct, re of the Scotia Sea and Falkland Plateau. Journal of Geophysical Research, 76(29), 7118-71_..

Figari, E. G., Cid de la Paz, M., \& Laffitte, G. A. (1997). Mn yelo de hemigrabenes en el neocomiamo del sector occidental de la cuenca del Golfo San Jorge, . rgentina: sistemas petroleros, origen e inversión tectónica. Boletin de Informaciones 'c; roleras, (52), 4-17.

Figari, E. G., Scasso, R., Cuneo, R., \& Escapa, I. (2C15). tstratigrafía y evolución geológica de la Cuenca de Cañadón Asfalto, provincia de' $\mathrm{Cr}$ ıbuı. Latin American Journal of Sedimentology, 22(January).

Figueiredo, A. M. F., Miranda, A. P., Ferre. ' `. R., \& Zalán, P. V. (1996). Cuenca de San Julián. In V. A. Ramos \& M. A. Turic (Eds.), G ol s'ín y Recursos Naturales de la Plataforma Continental Argentina (pp. 193-212). Buen - A Petróleo.

Fitzgerald, M. G., Mitchum, R. .1. L'iliana, M. A., \& Biddle, K. T. (1990). Evolution of the San Jorge Basin, Argentina. The Arı. sric xn Association of Petroleum Geologists Bulletin , 74(6), 879-920.

Flowerdew, M.J., Milla, I.L., V? ıghan, A.P.M., Horstwood, M.S.A., Fanning, C.M., 2006. The source of granitic gneisses and 1 igmatites in the Antarctic Peninsula: a combined U-Pb SHRIMP and laser ablation Hf isotope suddy of complex zircons. Contrib. Mineral. Petrol. 151, 751-768.

Folguera, A.; Ianizzotto, N.F. (2004). The lagos La Plata and Fontana fold-and-thrust belt: long lived orogenesis at the edge of Western Patagonia. Journal of South American Earth Sciences, v. 16, p. 541-466

Fourché, J., Bate, K. J., \& van der Merwe, R. (1992). Plate tectonic setting of the Mesozoic Basins, southern offshore, South Atlantic: A review. In M. de Wit \& I. G. D. Ransome (Eds.), Inversion Tectonics of the Cape Fold Belt, Karoo and Cretaceous Basins of Southern Africa (pp. 33-45). Rotterdam: Balkema.

Franke, D. (2013). Rifting, lithosphere breakup and volcanism: Comparison of magma-poor and volcanic rifted margins. Marine and Petroleum Geology, 43, 63-87. https://doi.org/10.1016/j.marpetgeo.2012.11.003

Franke, D., Ladage, S., Schnabel, M., Schreckenberger, B., Reichert, C., \& Hinz, K. (2010). Birth of a 
volcanic margin off Argentina, South Atlantic. Geochemistry Geophysics Geosystems, 11(2), 120.

Franke, D., Neben, S., Ladage, S., Schreckenberger, B., \& Hinz, K. (2007). Margin segmentation and volcano-tectonic architecture along the volcanic margin off Argentina/Uruguay, South Atlantic. Marine Geology, 244(1-4), 46-67. https://doi.org/10.1016/j.margeo.2007.06.009

Franke, D., Neben, S., Schreckenberger, B., Schulze, A., Stiller, M., Krawczyk, C. M. (2006). Crustal structure across the Colorado Basin, offshore Argentina. Geophysical Journal International, 165(3), 850-864. https://doi.org/10.1111/j.1365-246X.2006.02907.x

Franzese, J., Spalletti, L., Pérez, I. G., \& Macdonald, D. (2003). Tectonic and paleoenvironmental evolution of Mesozoic sedimentary basins along the Andean foothills of Argentina $\left(32^{\circ}-54^{\circ} \mathrm{S}\right)$. Journal of South American Earth Sciences, 16(1), 81-90. https://doi.org/10.1016/S08959811(03)00020-8

Fraticelli, C. M., Yezerski, D. J., Mercer, J. A., Yusri, Y., Salamoff, s., 1 ?ece, J., ... Bova, J. (2016). Rift basin characteristics derived from antecedents tectonic ev $\urcorner n^{\prime}$.s: intricacies of the Falkland plateau. In AAPG Annual Convention and Exhibition 2016 Ho ston.

Frizon De Lamotte, D., Fourdan, B., Leleu, S., Leparmentier, $r$. . ' De Clarens, P. (2015). Style of rifting and the stages of Pangea breai ' $D$. Tectonics, 34(5), 1009-1029. https://doi.org/10.1002/2014TC003760

Galeazzi, J. S. (1998). Structural and Stratigraphic Fv ' uti sn of the Western Malvinas Basin, Argentina. AAPG Bulletin, 82(4), 596-659. https://doi.org/10.1306/1D9BC5C5-172D-11D7$8645000102 C 1865 \mathrm{D}$

Galliski, M. A., \& Viramonte, J. G. (198?). The (retaceous paleorift in northwestern Argentina : A petrologic approach. Journal of So'th ' merican Earth Sciences, I(4), 329-342.

Gebhard, I. (2005). Aspectos explore`^ric - de la Cuenca del Colorado, in: de Barrio, R.E., Etcheverry, R.O., Caballé, M.F., Llambías, E.J. (Eds.), Geología y Recursos Minerales de La Provincia de Buenos Aires. Asociación Gc llógıca Argentina, La Plata, pp. 447-458.

Gerster, R., Welsink, H., Arı: ᄀ, A., \& Raggio, F. (2011). Cuenca de Colorado. VIII Congreso de Exploración y Desarr Ilo i? Hidrocarburos Simposio Cuencas Argentinas: Visión Actual, 65-80.

Geoffroy, L. (2005). Volcanı`passive margins. C. R. Geoscience., v. 337, p. 1395-1408.

Ghidella, M. E., Yáñez, G., \& LaBrecque, J. L. (2002). Revised tectonic implications for the magnetic anomalies of the western Weddell Sea. Tectonophysics, 347(1-3), 65-86. https://doi.org/10.1016/S0040-1951(01)00238-4

Ghiglione, M. C., \& Cristallini, E. O. (2007). Have the southernmost Andes been curved since Late Cretaceous time? An analog test for the Patagonian Orocline. Geology, 35(1), 13-16. https://doi.org/10.1130/G22770A.1

Gianni, G. M., Navarrete, C. G., \& Folguera, A. (2015). Synorogenic foreland rifts and transtensional basins: A review of Andean imprints on the evolution of the San Jorge Gulf, Salta Group and Taubat?? Basins. Journal of South American Earth Sciences, 64(February 2016), 288-306. https://doi.org/10.1016/j.jsames.2015.08.004

Gladczenko, T. P., Hinz, K., Eldholm, O., Meyer, H., Neben, S., \& Skogseid, J. (1997). South Atlantic volcanic margins. Journal of the Geological Society, 154(Gladczenko 1994), 465-470. 
https://doi.org/10.1144/gsjgs.154.3.0465

Gladczenko, T. P., Skogseid, J., \& Eldhom, O. (1998). Namibia volcanic margin. Marine Geophysical Researches, 20(4), 313-341. https://doi.org/10.1023/A:1004746101320

Glennie, K. W. \& Boegner, P. L. E. (1981). Sole Pit inversion tectonics. In: Illing, L. V. \& Hobson, G. D. (eds) Petroleum Geology of the Continental Shelf of NW Europe. Institute of Petroleum, London, pp. 110-120.

Goodlad, S.W., Martin, A.K., Hartnady, C.J.H., 1982. Mesozoic magnetic anomalies in the southern Natal Valley. Nature. http://dx.doi.org/10.1038/295686a0.

Gray, D. R., Foster, D. A., Meert, J. G., Goscombe, B. D., Armstrong, R., Trouw, R. A. J., \& Passchier, W. (2008). A Damara orogen perspective on the assembly of southwestern Gondwana. Geological Society, London, Special Publications, 294(May), 257-278. httr s://doi.org/10.1144/SP294.14

Guillocheau, F., Robin, C., \& Liget-Le Roux, A. (2018). Les rifts Kar', ` ’n ,ifrique: Leur signification à l'échelle du Gondwana et de la subduction de la Panthalass. G' ochronique, 145, 52-56.

Gust, D.A., Biddle, K.T., Phelps, D.W., Uliana, M.A., (198r). 4s'ociated Middle to Late Jurassic Volcanism and Extension in Southern South Americs $7_{t}$-tonophysics, v. 116, pp. 223-253.

Haller, M. J. (2002). La Cuenca Triásica de El Tranquilo I. M. J. Haller (Ed.), Geología y Recursos Naturales de Santa Cruz (pp. 83-87). Buenos firr s: Asociación Geológica Argentina.

Hälbich, I.W. 1983. A tectonogenesis of the Cane : ᄀld selt, in: Söhnge, A.P.G. and Hälbich, I.W. (eds.), Geodynamics of the Cape Fold Belt. Th : G $\epsilon$ Jlogical Society of South Africa, Special Publication, v. 12 , p. $165-175$.

Hansma, J., Tohver, E., Schrank, C., Jourdan, ᄃ., \& Adams, D. (2016). The timing of the Cape Orogeny : New $40 \mathrm{Ar} / 39 \mathrm{Ar}$ age constrain S ' J Jeformation and cooling of the Cape Fold Belt, South Africa. Gondwana Research, 3., 12 _ 137. https://doi.org/10.1016/j.gr.2015.02.005

Hartnady, C. J. H., Joubert, P., : Sto.ve, C. (1985). Proterozoic crustal evolution in southwestern Africa. Episodes, 8(4), 236-:14.

Heine, C., Zoethout, J., \& N'uir rr, R. D. (2013). Kinematics of the South Atlantic rift. Solid Earth, 4(2), 215-253. https://่i.. ro' $10.5194 /$ se-4-215-2013

Heron, P. J., \& Lowman, J. D. (2011). The effects of supercontinent size and thermal insulation on the formation of mantle plumes. Tectonophysics, 510(1-2), 28-38. https://doi.org/10.1016/j.tecto.2011.07.002

Hervé, F. and Fanning, C. M. (2001). Late Triassic detrital zircons in meta-turbidites of the Chonos Metamorphic Complex, southern Chile. Andean Geology, 28(1), 91-104.

Hinz, K. (1981). A hypothesis on terrestrial catastrophes. Wedges of very thick Oceanward Dipping Layers beneath Passive Continental Margins. Their origin and paleoenvironmental significance. Geol. Jb., 22, 3-28.

Hinz, K., Neben, S., Schreckenberger, B., Roeser, H. A., Block, M., \& Meyer, H. (1999). The Argentine continental margin north of $48^{\circ} \mathrm{S}$ :sedimentary successions, volcanic activity du ring breakup. Marine and Petroleum Geology, 16, 1-25.

Homovc, J. F. and Constantini, L. (2001). Hydrocarbon exploration potential within intraplate shear- 
related depocenters: Deseado and San Julián basins, southern Argentina. AAPG Bulletin, 85(10), 1795-1816.

lannizzotto, N. F., Folguera, A., Leal, P. R., laffa, D. (2004). Control tectónico de las secuencias volcaniclásticas neocomianas y paleogeografía en la zona del Lago La Plata $\left(45^{\circ} \mathrm{S}\right)$. Sector interno de la faja plegada y corrida de los lagos La Plata y Fontana. Revista de La Asociacion Geologica Argentina, 59(4), 655-670. https://doi.org/10.2307/198976

Kay, S.M., Ramos, V.A., Mpodozis, C., y Sruoga, P., 1989. Late Paleozoic to Jurassic silicic magmatism at the Gondwana margin: analogy to middle Proterozoic in North America? Geology 17, 324e328. Boulder.

Keeley, M.L., Light, M.P.R., 1993. Basin Evolution and Prospectivity of the Argentine Continental Margin. J. Pet. Geol. 16, 451-464. https://doi.org/10.1111/j.1747-5457.1993.tb00352.x

Introcaso, A., Ramos, V.A., 1984. La cuenca de Salado_un modelo de svolucion aulacogenica, in: IX Congreso Geológico Argentino. San Carlos de Bariloche, pp 27- 16.

Jenchen, U., \& Rosenfeld, U. (2002). Continental Triassic in Arદ ent, aa: Response to tectonic activity. Journal of South American Earth Sciences, 15(4), 4,1-'?' https://doi.org/10.1016/S08959811(02)00049-4

Jokat, W., Boebel, T., König, M. \& Meyer, U. (2003). T11. Ing and geometry of eatly Gondwana breakup- Journal of Geophysical Research, v. 'vi, no. B9, 2428, doi:10.1029/2002JB001802

Jourdan, F., Bertrand, H., \& Watkeys, M. K. '20u/). From flood basalts to the inception of oceanization: Example from the $40 \mathrm{Ar} / 39, \mathrm{r}$ hish-resolution picture of the Karoo large igneous province. Geochemistry - 'sophysics Geosystems, 8(2), 20. https://doi.org/10.1029/2006GCOC:392

Jourdan, F., Féraud, G., Bertrand, H., Kám'ınzu, A. B., Tshoso, G., Le Gall, B., ... Capiez, P. (2004). The Karoo triple junction questione-1 e : geochemistry of the giant $S_{\text {i: }}$ эvango dyke swarm (Botswana ). Earth and Planetary Science Letters, 222, 989-1006. http. $/ /$ doi.org/10.1016/j.epsl.2004.03.017

Jourdan, F., Féraud, G., Bertra’d, 1., Kampunzu, A. B., Tshoso, G., Watkeys, M., \& Le Gall, B. (2005). Karoo large igneous Jro ince: Brevity, origin , and relation to mass extinction questioned by new 40Ar/39Ar agt Jac.. Geology, 33(9), 745-748. https://doi.org/10.1130/G21632.1

Jungslager, E. H. A. (1996). jeological evaluation of the remaining prospectivity for oil and gas of the pre-1At1 "synrift" succession in Block 9, Republic of South Africa.

Jungslager, E. H. A. (1999). Petroleum habitats of the Atlantic margin of South Africa. Geological Society, London, Special Publications, 153(1), 153-168. https://doi.org/10.1144/GSL.SP.1999.153.01.10

Kay, S.M., 1993. Late Paleozoic tectonics in Southern South America: a global perspective, in: Douzieme Congres International de La Stratigraphie et Geologie Du Carbonifere et Permien, Comptes Rendus I. Buenos Aires, pp. 109-122.

Kay, S.M., Ramos, V.A., Mpodozis, C., Sruoga, P., 1989. Late Paleozoic to Jurassic silicic magmatism at the Gondwana margin: Analogy to the Middle Proterozoic in North America? Geology, v. 17, pp. 324-328. 
Kay, S.M., Ramos, V.A. and Marquez, M. 1993. Evidence in Cerro Pampa volcanic rocks for slabmelting prior to ridge-trench collision in Southern South America. Journal of Geology 101: 703-714.

Keidel, J., 1916. La geología de las Sierras de la Provincia de Buenos Aires y sus relaciones con las montañas de Sudáfrica y Los Andes. In: Ministerio de Agricultura de La Nación, Sección Geología, Mineralogía y Minería, Anales, vol. 11(3), pp. 1e78, Buenos Aires.

Keidel, J., 1921. Sobre la distribucion de los depositos glaciares del Permico conocidos en la Argentina y su significacion para la estratigrafía de la serie del Gondwana y la paleogeografía del Hemisferio Austral, vol. 25. Academia Nacional de Ciencias, Boletín, Cordoba, pp. 239-368.

Kimbell, G. S., Richards, P. C. (2008). The three-dimensional lithospheric structure of the Falkland Plateau region based on gravity modelling. Journal of the Genlogical Society, 165, 795-806.

Klausen, M. B. (2009). The Lebombo monocline and associated feere, Jyke swarm: Diagnostic of a successful and highly volcanic rifted margin? Tt ton physics, 468(1-4), 42-62. https://doi.org/10.1016/j.tecto.2008.10.012

Kokogian, D., Mancilla, O. H. (1989). Análisis Estratigráfico - ’cuencial de la Cuenca Cuyana. In G. A. Chebli \& L. Spalletti (Eds.), Cuencas Sedimentaria, A, rentinas (pp. 169-201). San Miguel de Tucuman: Instituto Superior de Correlación Geológlu-

König, M., Jokat, W. (2006). The Mesozoic break גp $\mathrm{c}^{\mathrm{f}}$ the Weddell Sea. Journal of Geophysical Research: Solid Earth, 111(12), 1-28. https:/. do, ..ig/10.1029/2006JB004035

Koopmann, H., Franke, D., Schreckenberge: , B. schulz, H., Hartwig, A., Stollhofen, H., \& di Primio, R. (2014). Segmentation and volcano-tectu. ic characteristics along the SW African continental margin, South Atlantic, as derived $t ı m$ multichannel seismic and potential field data. Marine and Petroleum Geology, 50, 22-3r. I 'ps://doi.org/10.1016/j.marpetgeo.2013.10.016

Kostadinoff, J., \& Llambías, E. (200:). - 'iencas sedimentarias en el subsuelo de la Provincia de La Pampa. In 5 Congreso de Ex olc.`ción y Desarrollo de Hidrocarburos (p. 9). Instituto Argentino del Petróleo y del Gas.

Kozlowsky, E., Legarreta, I, BC"', A., \& Marshall, P. (2011). Simposio Cuencas Argentinas, Visión Actual. (E. Kozlc'vslv, L Legarreta, A. Boll, \& P. Marshall, Eds.). Buenos Aires: Instituto Argentino del Petróı ? y del Gas.

Kristoffersen, Y., Hofstede, C., Diez, A., Blenkner, R., Lambrecht, A., Mayer, C., \& Eisen, O. (2014). Reassembling Gondwana: A new high quality constraint from vibroseis exploration of the subice shelf geology of the East Antarctic continental margin. Journal of Geophysical Research: Solid Earth, 119, 1-12. https://doi.org/10.1002/2014JB011479. Received

Lagorio, S. L. (2008). Early Cretaceous alkaline volcanism of the Sierra Chica de Córdoba (Argentina): Mineralogy, geochemistry and petrogenesis. Journal of South American Earth Sciences, 26(2), 152-171. https://doi.org/10.1016/j.jsames.2008.05.003

Lagorio, S. L., Vizán, H., \& Geuna, S. E. (2016). Early Cretaceous Volcanism in Central and Eastern Argentina During Gondwana Break-Up.

Legarreta, L., \& Uliana, M. A. (1996). The Jurassic succession in west-central Argentina: stratal patterns, sequences and paleogeographic evolution. Palaeogeography, Palaeoclimatology, Palaeoecology, 120(3-4), 303-330. https://doi.org/10.1016/0031-0182(95)00042-9 
Leleu, S., Hartley, A. J., van Oosterhout, C., Kennan, L., Ruckwied, K., \& Gerdes, K. (2016). Structural, stratigraphic and sedimentological characterisation of a wide rift system: The Triassic rift system of the Central Atlantic Domain. Earth-Science Reviews, 158, 89-124. https://doi.org/10.1016/j.earscirev.2016.03.008

Leroy, S., Lucazeau, F., D’Acremont, E., Watremez, L., Autin, J., Rouzo, S., ... Khanbari, K. (2010). Contrasted styles of rifting in the eastern Gulf of Aden: A combined wide-angle, multichannel seismic, and heat flow survey. Geochemistry, Geophysics, Geosystems, 11(7). https://doi.org/10.1029/2009GC002963

Leroy, S., Razin, P., Autin, J., Bache, F., d'Acremont, E., Watremez, L., ... Al Lazki, A. (2012). From rifting to oceanic spreading in the Gulf of Aden: A synthesis. Arabian Journal of Geosciences, 5(5), 859-901. https://doi.org/10.1007/s12517-011-0475-4

Linol, B., \& Wit, M. J. De. (2016). Origin and Evolution of the Cape N'cuntains and Karoo Basin.

Livermore, R.A. \& Hunter, R.J. (1996). Mesozoic seafloor spreadin, In the southern Weddell Sea. In: Storey, B.C., King, E.C., \& Livermore, R.A. (eds.). Weddell Sea i n+t unics and Gondwana breakup. Geological Society, London, Special Publicacion v. 108, k 22; 241.

Loegering, M. J., Anka, Z., Autin, J., di Primio, R., March-1, IJ., Rodriguez, J. F., ... Vallejo, E. (2013). Tectonic evolution of the Colorado Basin, offshore ' ' gen :ina, inferred from seismo-stratigraphy and depositional rates analysis. -’ctonophysics, 604, 245-263. https://doi.org/10.1016/j.tecto.2013.02.008

Lohr, T., \& Underhill, J. R. (2015). Role of rit transection and punctuated subsidence in the development of the North Falkl nd Basin. Petroleum Geoscience, 21(2-3), 85-110. https://doi.org/10.1144/petgeo2014-05

Lovecchio, J. P., Rohais, S., Joseph, P.. Roı +ti, N., Kress, P. R., Gerster, R., \& Ramos, V. A. (2018). Multi-stage rifting evolution 0 h. Colorado basin (offshore Argentina): Evidence for extensional settings pric, iv the South Atlantic opening. Terra Nova. https://doi.org/10.1111/ter 1<:51

Lovecchio, J.P., Naipauer, M., Ca.'O. L.E., Rohais, S., Giunta, D., Flores, G., Gerster, R., Bolatti, N.D., Joseph, P., Valencia, V A., ?'?'nos, V.A. (2019). Rifting evolution of the Malvinas basin, offshore Argentina: New cor straı is from zircon U-Pb geocrhonology and seismic characterization. Journal of South An. rican Earth Sciences, v. 95, https://doi.org/10.1016/j.jsames.2019.102253

Lundin, E.R., Redfield, T.F. «Péron-Pinvidic, G. 2014. Rifted continental margins: Geometric influence on crustal architecture and melting. In: Pindell, J., Horn, B. et al. (eds) Sedimentary Basins: Origin, Depositional Histories and Petroleum Systems - 33rd Annual Gulf Coast Section SEPM Foundation Bob F. Perkins Research Conference. Gulf Coast Section SEPM(GCSSEPM), Houston, TX, 26-28.

Ludwig, W.J., Ewing, J.I., Ewing, M. 1968. Structure of Argentine Continental Margin. AAPG Bulletin, v. 52 , p. $2337-2368$

Macdonald, D., Gomez-Perez, I., Franzese, J., Spalletti, L., Lawver, L., Gahagan, L., ... Paton, D. (2003). Mesozoic break-up of SW Gondwana: Implications for regional hydrocarbon potential of the southern South Atlantic. Marine and Petroleum Geology, 20(3-4), 287-308. https://doi.org/10.1016/S0264-8172(03)00045-X

Macgregor, D. (2017). History of the development of Permian-Cretaceous rifts in East Africa: a series of interpreted maps through time. Petroleum Geosicence. 
https:\\doi.org\10.1144\petgeo2016-155

Mahanjane, E. S. (2012). A geotectonic history of the northern Mozambique Basin including the Beira High - A contribution for the understanding of its development. Marine and Petroleum Geology, 36(1), 1-12. https://doi.org/10.1016/j.marpetgeo.2012.05.007

Maksaev, V., Munizaga, F., \& Tassinari, C. (2014). Timing of the magmatism of the paleo-Pacific border of Gondwana: U-Pb geochronology of Late Paleozoic to Early Mesozoic igneous rocks of the north Chilean Andes between $20^{\circ}$ and $31^{\circ}$ S. Andean Geology, 41(3), 447-506. https://doi.org/10.5027/andgeoV41n3-a01

Malkowski, M. A., Grove, M., \& Graham, S. A. (2015). Unzipping the Patagonian Andes - Long-lived influence of rifting history on foreland basin evolution, (5), 1-7. https://doi.org/10.1130/L489.1

Marcano, M.C., Van der Voo, R., Mac Niocaill, C., 1999. True polar wander during the Permo-Triassic. J. Geodyn., v. 28, pp. 75-95.

Marshall, J. E. A. (1994). The Falkland Islands and the early fragme, tati sn of Gondwana: implications for hydrocarbon exploration in the Falkland Plateau. I ları e and Petroleum Geology, 11(5), 631-636. https://doi.org/10.1016/0264-8172(94)90073. 6

Marsicano, C. A., Irmis, R. B., Mancuso, A. C., Mundil, R., ' ‘ Ch، male, F. (2016). The precise temporal calibration of dinosaur origins. In Proceedings of the vational Academy of Sciences (Vol. 113, pp. 509-513). https://doi.org/10.1073/pnas.15 12541112

McDermott, C., Lonergan, L., Collier, J. S., McDerr' ' ttt, א. G., \& Bellingham, P. (2018). Characterization of seaward-dipping reflectors along t'ie : outı. American Atlantic margin and implications for continental breakup. Tectonics, 37, 330 -3327. https://doi.org/10.1029/2017TC004923

McHone, J. G. (2000). Non-plume magmai:- $m$ and rifting during the opening of the central Atlantic Ocean. Tectonophysics, 316(3-4). 2\&, ?.96. https://doi.org/10.1016/S0040-1951(99)00260-7

McMillan, I. K. (2003). Foraminifera ly a fined biostratigraphic episodes and sedimentation pattern of the Cretaceous drift suc'essı n (Early Barremian to Late Maastrichtian) in seven basins on the South African and soui arı. Namibian continental margin. South African Journal of Science, 99(11-12), 537-576.

Micucci, E., Continanzi. J., Mr.ıceda, R., \& Gavarrino, A. (2011b). Cuenca de San Julián: Síntesis del conocimiento explor c torio - Visión Actual. In Simposio Cuencas Argentinas Visión Actual: VIII Congreso de Exploıu ión y Desarrollo de Hidrocarburos (pp. 17-46). Buenos Aires: Instituto Argentino del Petróleo y del Gas.

Milana, J. P., \& Alcober, O. (1994). Modelo tectosedimentario de la cuenca triásica de Ischigualasto (San Juan, Argentina). Revista de La Asociacion Geologica Argentina , 49(3-4), 217-235.

Millar, I.L., Pankhurst, R.J., Fanning, C.M., 2002. Basement chronology of the Antarctic Pen insula: recurrent magmatism and anatexis in the Palaeozoic Gondwana margin. J. Geol. Soc. Lond. 159, 145-157.

Miller, W., de Wit, M.J., Linol, B., and Armstrong, R., 2016. New Structural Data and U/Pb Dates from the Gamtoos Complex and Lowermost Cape Supergroup of the Eastern Cape Fold Belt, in Support of a Southward Paleo-Subduction Polarity. In de Wit, M.J., Linol, B. (eds.) Origin and Evolution of the Cape Mountains and Karoo Basin, Regional Geology Reviews, p. 35-44.

Milner, S. C., Duncan, A. R., Whittingham, A. M., \& Ewart, A. (1995). Trans-Atlantic correlation of 
eruptive sequences and individual silicic volcanic units within the Paran??-Etendeka igneous province. Journal of Volcanology and Geothermal Research, 69(3-4), 137-157. https://doi.org/10.1016/0377-0273(95)00040-2

Mohriak, W. U., \& Leroy, S. (2013). Architecture of rifted continental margins and break-up evolution: insights from the South Atlantic, North Atlantic and Red Sea-Gulf of Aden conjugate margins. Geological Society, London, Special Publications, 369(1), 497-535. https://doi.org/10.1144/SP369.17

Mosquera, A., Ramos, V. A. (2006). Intraplate deformation in the Neuquén Embayment. Geological Society of America Special Papers, 407(05), 97-123. https://doi.org/10.1130/2006.2407(05).

Moulin, M., and Aslanian, D. (2010). Corrigendum to "A new starting point for the South and Equatorial Atlantic Ocean" [Earth Science Reviews 98 (2010), 1-37]. Earth-Science Reviews, 103(3-4), 197-198. https://doi.org/10.1016/j.earscirev.2010.. 0001

Moulin, M., Aslanian, D., and Unternehr, P. (2010). A new starting J01, + for the South and Equatorial Atlantic Ocean. Earth-Science Reviev.c 98(1-2), 1-37. https://doi.org/10.1016/j.earscirev.2009.08.001

Mpodozis, C., Ramos, V. A. (2008). Tectónica Jurásica en ^^rgu ntina y Chile: Extensión, subducción oblicua, rifting, deriva y colisiones? Revista de La. 'soc xcion Geologica Argentina, 63(4), 481497.

Mueller, C. O., and Jokat, W. (2017). Geophysical ev. 'en .e for the crustal variation and distribution of magmatism along the central coast of i' 'nzambique. Tectonophysics, 712-713, 684-703. https://doi.org/10.1016/j.tecto.2017.' 5.0r 7

Mukasa, S. B., and Dalziel, I. W. D. (15?6). Souchernmost Andes and South Georgia Island, North Scotia Ridge : Zircon U-Pb and muccov ite 40Ar / 39Ar age constraints on tectonic evolution of Southwestern Gondwanaland. JC ג'nc i of South American Earth Sciences, 9(5-6), 349-365.

Musset, A.E. and Taylor, G.K. (15:4). ${ }^{9} \mathrm{Ar}-{ }^{39} \mathrm{Ar}$ ages for dykes from the Falkland Islands with implications for the breaku. ? of southern Gondwanaland. Journal of the Geological Society, London, v. 151, p. 79-81.

Naipauer, M., Garcia Mo abı. J, E., Manassero, M., Valencia, V. V, \& Ramos, V. A. (2018). A Provenance Analy. $s, \cdots$. n the Lower Jurassic Units of the Neuqu é $n$ Basin. Volcanic Arc or Intraplate Magmatic nput? In A. Folguera \& et al. (Eds.), The Evolution of the ChileanArgentinean Andes (pp. 191-222). Springer International Publishing.

Nairn, A. E. M., Lerche, I., \& lliffe, J. E. (1991). Geology, basin analysis, and hydrocarbon potential of Mozambique and the Mozambique Channel. Earth Science Reviews, 30(1-2), 81-123. https://doi.org/10.1016/0012-8252(91)90014-7

Navarrete, C., Gianni, G., Encinas, A., Márquez, M., Kamerbeek, Y., Vale, M., Folguera, A. (2019). Triassic to Middle Jurassic geodynamic evolution of southwestern Gondwana: From a large flatslab to mantle plume suction in a rollback subduction setting. Earth Science Reviews, v. 194, pp. 125-159. https://doi.org/10.1016/j.earscirev.2019.05.002

Nürnberg, D., \& Müller, R. D. (1991). The tectonic evolution of the South Atlantic from Late Jurassic to present. Tectonophysics, 191(1-2), 27-53. https://doi.org/10.1016/0040-1951(91)90231-G

Olivero, E. B. (1987). Cefalopodos y bivalvos Titonianos y Hauterivianos de la Formación Lago La Plata, Chubut. Ameghiniana, 24(3-4), 181-202. 
Olivero, E. B., \& Aguirre-Urreta, M. B. (2002). Sucesion de amonoideos de la Formacion Katterfeld (Valanginiano-Hauteriviano) en su area tipo, Lago Fontana, Chubut. In XV Congreso Geologico Argentino. El Calafate.

Oliveros, V., González, J., Espinoza Vargas, M., Vásquez, P., Rossel, P., Creixell, C., ... Bastias, F. (2018). The Early Stages of the Magmatic Arc in the Southern Central Andes. In A. Folguera, E. Contreras-Reyes, N. Heredia, A. Encinas, S. B. Iannelli, V. Oliveros, ... C. Arriagada (Eds.), The Evolution of the Chilean-Argentinean Andes (pp. 165-190). Springer Nateure.

Otis, R. M., \& Schneidermann, N. (2000). A failed hydrocarbon system - Rawson Basins, Argentina. In Petroleum systems of South Atlantic margins. AAPG Memoir 73 (Vol. 73, pp. 417-428). Retrieved from http://search.datapages.com/data/specpubs/memoir73/m73ch28/m73ch28.htm

Pángaro, F., Pereira, D.M., Micucci, E. (2009). El Synrift de la Dors ^l de Huincul, Cuenca Neuquina: Evolución y control sobre la estratigrafía y estructura del áı z. Revista de la Asociación Geológica Argentina, v. 65, n. 2, pp. 265-277.

Pángaro, F., Ramos, V. A. (2012). Paleozoic crustal blocks of on hor and offshore central Argentina: New pieces of the southwestern Gondwana collage an the "I role in the accretion of Patagonia

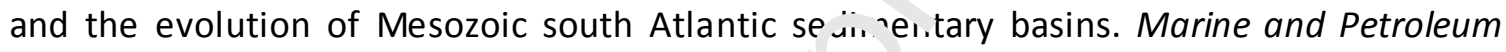
Geology, 37(1), 162-183. https://doi.org/10.1016/j..' 'arr, etgeo.2012.05.010

Pángaro, F., Ramos, V.A. and Pazos, P.J. 2016. Tre iesperides basin: a continental-scale upper Palaeozoic to Triassic basin in southern Gor $d_{w}>n_{1}$. Basin Research 28(5): 685-711.

Pankhurst, R. J., Leat, P. T., Sruoga, P., Rape' a, C W., Márquez, M., Storey, B. C., \& Riley, T. R. (1998). The Chon Aike province of Patagonia anc -olated rocks in West Antarctica: a siliciclarge igneous province. Journal of Volcanu'nqy and Geothermal Research, 81(1-2), 113-136. https://doi.org/10.1016/S0377-02-:'9/, J0070-X

Pankhurst, R. J., Rapela, C. W., Få.1. 'n $n_{5}$ C. M., \& Márquez, M. (2006). Gondwanide continental collision and the origir of Patagonia. Earth-Science Reviews, 76(3-4), 235-257. https://doi.org/10.1016/j e. - - cirev.2006.02.001

Pankhurst, R. J., Riley, T. R. - эr.ning, C. M., \& Kelley, S. P. (2000). Episodic silicic volcanism in Patagonia and the Ar tarci $\mathrm{C}$ Peninsula: Chronology of magmatism associated with the break-up of Gondwar. Journal of Petrology, 41(5), 605-625. https://doi.org/10.10 $3 /$ petrology/41.5.605

Paton, D. A. (2006). Influence of crustal heterogeneity on normal fault dimensions and evolution: southern South Africa extensional system. Journal of Structural Geology, 28, 868-886. https://doi.org/10.1016/j.jsg.2006.01.006

Paton, D. A., Mortimer, E. J., Hodgson, N., \& Van Der Spuy, D. (2016). The missing piece of the South Atlantic jigsaw - when continental break-up ignores crustal heterogeneity. Petroleum Geoscience of the West Africa Margin, Geological Society, London, Special Publications, 438. https://doi.org/http://doi.org/10.1144/SP438.8

Paton, D. A., Pindell, J., Mcdermott, K., Bellingham, P., \& Horn, B. (2017). Evolution of seawarddipping reflectors at the onset of oceanic crust formation at volcanic passive margins : Insights from the South Atlantic, (5), 439-442. https://doi.org/10.1130/G38706.1

Paton, D. A., \& Underhill, J. R. (2004). Role of crustal anisotropy in modifying the structural and sedimentological evolution of extensional basins: the Gamtoos Basin, South Africa. Basin 
Research, 16, 339-359. https://doi.org/10.1111/j.1365-2117.2004.00237.x

Peace, A.L., Phethean, J.J.J., Franke, D., Foulger, G.R., Schiffer, C., Welford, J.K., McHone, G., Rocchi, S., Schnabel, M., Doré, A.G. (2019). A review of Pangaea dispersal and Large Igneous Provinces In search of a causative mechanism. Earth Science Reviews. In press. https://doi.org/10.1016/j.earscirev.2019.05.009

Pindell, J., Graham, R., \& Horn, B. (2014). Rapid outer marginal collapse at the rift to drift transition of passive margin evolution, with a Gulf of Mexico case study. Basin Research, 26(6), 701-725. https://doi.org/10.1111/bre.12059

Pinto, V. M., Hartmann, L. A., Santos, J. O. S., McNaughton, N. J., \& Wildner, W. (2011). Zircon U-Pb geochronology from the Paraná bimodal volcanic province support a brief eruptive cycle at 135Ma. Chemical Geology, 281(1-2), 93-102. https://doi.org/10.1016/j.chemgeo.2010.11.031

Planke, S., Symonds, P. A., Alvestad, E., \& Skogseid, J. (2000). Seism، volcanostratigraphy of large volume basaltic extrusive complexes on rifted margins. Jou nai of Geophysical Research: Solid Earth, 105(B8), 19335-19351. https://doi.org/10.1029/199alb? ?,005

Price, G. D., \& Gröcke, D. R. (2002). Strontium-isotope stratiı rap', and oxygen- and carbon-isotope variation during the Middle Jurassic-Early Cretace ${ }^{\cdots}-0_{i}{ }^{\text {t }}$ he Falkland Plateau, South Atlantic. Palaeogeography, Palaeoclimatology, Flaec ecology, 183(3-4), 209-222. https://doi.org/10.1016/S0031-0182(01)00486-2

Quirk, D. G., Shakerley, A., Howe, M. J. (2014). A r.le hanism for construction of volcanic rifted margins during continental b. sakup. Geology, 42(12), 1079-1082. https://doi.org/10.1130/G35974.1

Rabinowitz, P.D., and LaBreque, J. (19-?). The Mesozoic South Atlantic Ocean and Evolution of its Conjugate Margins. J. Geophys. Re- 8r, 5973-6002.

Raggio, F., Welsink, H., Fiptiani, N, Pr. ...cno, W., Gerster, R., 2011. Cuenca Malvinas. VIII Congr. Explor. y Desarro. Hidrocarb'ג `simp. Cuencas Argentinas visión actual 1-16.

Ramos, V.A., 1981. Descripcio'r reolo'gica de la hoja 47 ab Lago Fontana, Provincia de Chubut. Servicio Geológico Nario, ’'. Bol., Buenos Aires 183, 130.

Ramos, V. A. (1996). Ev '1, (Eds.), Geología y Recı rsos Naturales de la Plataforma Continental Argentina (pp. 385-404).

Ramos, V.A. (1999) Rasgos estructurales del territorio argentino. In: Caminos, R. (ed.), Geología Argentina, Servicio Geológico Minero Argentino, Anales 29, chapter 24, p. 715-784.

Ramos, V.A., Aleman, A. (2000). Tectonic Evolution of the Andes. In: Cordani, U.G., Milani, E.J., Thomaz Filho, A., Campos, D.A. (eds.) Tectonic evolution of South America, Río de Janerio, pp. 635-685

Ramos, V. A. (2008). Patagonia: A paleozoic continent adrift? Journal of South American Earth Sciences, 26(3), 235-251. https://doi.org/10.1016/j.jsames.2008.06.002

Ramos, V. A. (2010). Pampia: A large cratonic block missing in the Rodinia supercontinent, (September). https://doi.org/10.1016/j.jog.2010.01.019

Ramos, V. A., Cingolani, C., Junior, F. C., Naipauer, M., \& Rapalini, A. (2017). The Malvinas (Falkland) Islands revisited: The tectonic evolution of southern Gondwana based on U-Pb and Lu-Hf 
detrital zircon isotopes in the Paleozoic cover. Journal of South American Earth Sciences, 76, 320-345. https://doi.org/10.1016/j.jsames.2016.12.013

Ramos, V. A., Folguera, A. (2009). Andean flat-slab subduction through time. In J. B. Murphy, J. D. Keppie, \&A.J. Hynes (Eds.), Ancient orogens and modern analogs. Geological Society of London SP 327 (pp. 31-54).

Ramos, V. A., Kay, S. M. (1991). Triassic rifting and associated basalts in the Cuyo basin, central Argentina, (October 2016), 79-92. https://doi.org/10.1130/SPE265-p79

Ramos, V. A., \& Palma, M. A. (1996). Tectónica del Pérmico de Argentina. In S. Archangelsky (Ed.), El sistema Pérmico en la República Argentina y en la República Oriental del Uruguay (pp. 239254). Códoba: Academia Nacional de Ciencias.

Ramos, V. A., \& Turic, M. A. (1996). Geología y Recursos Natura'es de la Plataforma Continental Argentina. (V. A. Ramos \& M. A. Turic, Eds.) (First). Buenu. Aires: Asociación Geológica Argentina; Instituto Argentino del Petróleo.

Rapela, C. W., Días, G. F., Franzese, J. R., Alonso, G., \& Ben ren. to, A. R. (1991). El Batolito de la Patagonia Central: Evidencias de un magmatismu isico-Jurásico asociado a fallas transcurrentes. Revista Geológica de Chile, 18(2), 121. 13i

Rapela, C.W., Pankhurst, R.J., 1992. The granites of northe I. Patagonia and the Gastre Fault System in relation to the break-up of Gondwana. In: '„ iey, B.C., Alabaster, T., Pankhurst, R.J. (Eds.), Magmatism and the Causes of Continental $3 r$ s up, vol. 68. The Geological Society, Special Publications, pp. 209-220.

Rapela, C.W. \& Kay, S., 1988. The Late Palt 'zoic to Recent magmatic evolution of northern Patagonia. Episodes, v. 11, pp. 175-1c?

Rapela, C. W., Pankhurst, R. J., Fannino, ( ' ., \& Herve, F. (2005). Pacific subduction coeval with the Karoo mantle plume: the i arly jurassic subcordilleran belt of northwestern Patagonia. Geological Society, (June 2C: 7), Li7-239. https://doi.org/10.1144/GSL.SP.2005.246.01.07

Renne, P. R., Glen, J. M., Milı. rr, S C., \& Duncan, A. R. (1996). Age of Etendeka flood volcanism and associated intrusi Jns in southwestern Africa. Geology, 24(7), 659-662. https://doi.org/14. ${ }^{1} 1$; ?/r,J91-7613(1996)024<0659:AOEFVA>2.3.CO;2

Richards, P.C., Hillier, B.V. ' 2000). Post-drilling Analysis of the North Falkland basin - Part 1: Tectonostratigraphic framework. Journal of Petroleum Geology, v. 23. n. 3, pp. 253-272

Riel, N., Jaillard, E., Martelat, J.-E., Guillot, S., \& Braun, J. (2018). Permian-Triassic Tethyan realm reorganization: Implications for the outward Pangea margin. Journal of South American Earth Sciences, 81, 78-86. https://doi.org/10.1016/j.jsames.2017.11.007

Riley, T.R., Flowerdew, M.J., Whitehouse, M.J., 2012. U-Pb ion-microprobe zircon geo-chronology from the basement inliers of eastern Graham Land, Antarctic Peninsula. Journal of the Geological Society, London 169, 381-393. https://doi.org/10.1144/ 0016-76492011-142.

Riley, T. R., Flowerdew, M. J., Pankhurst, R. J., Curtis, M. L., Millar, I. L., Fanning, C. M., \& Whitehouse, M. J. (2016). Early Jurassic magmatism on the Antarctic Peninsula and potential correlation with the Subcordilleran plutonic belt of Patagonia. Journal of the Geological Society, (Hathway 2000). https://doi.org/10.1144/jgs2016-053 
Rocher, S., Vallecillo, G., Castro de Machuca, B., Alasino, P. (2015). El Grupo Choiyoi (Pérmico temprano-medio) en la Cordillera Frontal de Calingasta, San Juan, Argentina: volcanismo de arco asociado a extensión. Revista Mexicana de Ciencias Geológicas, v. 32, pp. 415-432.

Rodríguez Raising, M., Mendez, M., Martinez Lampe, J.M. 2019. Methodology used in the exploration of a frontier area located in the Northeast of the Rio Negro Province, Argentina. AAPG International Conference and Exhibition 2019. Buenos Aires, Argentina

Sato, A.M., Llambias, E.J., Basei, M.A.S., Castro, C.A., 2015, Three stages in the Late Paleozoic to Triassic magmatism of southwestern Gondwana, and the relationships with the volcanogenic events in coeval basins: Journal of South American Earth Sciences, v. 63, pp. 48-69.

Schimschal, C.M., \& Jokat, W. (2019). The Falkland Plateau in the context of Gondwana breakup. Gondwana Research, v. 68, p. 108-115.

Schmidt, C. J., Astini, R. A., Costa, C. H., Gardini, C. E., \& Kraemer, , E. (1995). Cretaceous rifting, alluvial fan sedimentation, and Neogene inversion, Southerr sIt ras Pampeanas, Argentina. In A. Tankard, R. Suarez-S., \& H. J. Welsink (Eds.), Petroleum Lnci. ıs of South America (pp. 341358). AAPG Memoir 62.

Sengör, A. M. C., \& Burke, K. (1978). Relative timing of riftiñ $7_{1} .7$ volcanism on Earth and its tectonic implications. Geophysical Research Letters, 5, 419. 121.

Senkans, A., Leroy, S., d'Acremont E., Castilla, E., Der r nois, F., 2019. Polyphase rifting and break-ip of the central Mozambique margin. Marine эr. " Pf troleum Geology, v. 100, p. 412-433.

Smith, R. M. H., Eriksson, P. G., \& Botha, W J. ( 993). A review of the stratigraphy and sedimentary environments of the Karoo-aged basir.. of Southern Africa. Journal of African Earth Sciences, 16(1-2), 143-169. https://doi.org/110.1016/0899-5362(93)90164-L

Spalletti, L., Fanning, C. M., \& Rapela, C V . ' T008). Dating the Triassic continental rift in the southem Andes : the Potrerillos Format; - n. ¿-yo Basin, Argentina. Geologica Acta, 6(3), 267-283.

Spikings, R., Reitsma, M. J., Boekh ${ }^{h}$ ut, $5 .$, Mi, A., Ulianov, A., Chiaradia, M., ... Schaltegger, U. (2016). Characterisation of Triassic -ifl..ng in Peru and implications for the early disassembly of western Pangaea, 35, 124-143. hi.ns: /doi.org/10.1016/j.gr.2016.02.008

Starck, D. (2011). Cuen` `C ' ‘á', ica-Paleógena del Noroeste Argentino. In E. Kozlowsky, L. Legarreta, A. Boll, \& P. Marsha.' (Eds.), Simposio Cuencas Argentinas Visión Actual: VIII Congreso de Exploración y Desarı uio de Hidrocarburos (pp. 407-454). Buenos Aires: Instituto Argentino del Petróleo y del Gas.

Stern, C. R., Mukasa, S. B., \& Fuenzalida, R. (1992). Age and petrogenesis of the Sarmiento ophiolite complex of southern Chile. Journal of South American Earth Sciences, 6(1/2), 97-104.

Stica, J. M., Zalán, P. V., \& Ferrari, A. L. (2014). The evolution of rifting on the volcanic margin of the Pelotas Basin and the contextualization of the Paraná-Etendeka LIP in the separation of Gondwana in the South Atlantic. Marine and Petroleum Geology, 50, 1-21. https://doi.org/10.1016/j.marpetgeo.2013.10.015

Stipanicic, P. N. (2001). Antecedentes geológicos y paleontológicos. In A. E. Artabe, E. M. Morel, \& A. B. Zamuner (Eds.), El sistema Triásico en la Argentina (pp. 1-21). La Plata: Fundación Museo de la Plata "Francisco Pascasio Moreno."

Stipanicic, P. N., Bonaparte, J. F. (1979). Cuenca Triasica de Ischigualasto-Villa Unión (Provincias de La 
Rioja y San Juan). In Segundo Simposio de Geología Regional Argentina I (pp. 523-576).

Stipanicic, P.N., Methol, E.L., 1972. Macizo de Somun Cura. In: Leanza, A.F. (Ed.): Geología Regional Argentina. Academia Nacional de Ciencias, v. 1, pp. 581-599.

Stollhofen, H., Gerschütz, S., Stanistreet, I. G., \& Lorenz, V. (1998). Tectonic and volcanic controls on Early Jurassicrift-valley lake deposition during emplacement of Karoo flood basalts, southern Namibia. Palaeogeography, Palaeoclimatology, Palaeoecology, 140(1-4), 185-215. https://doi.org/10.1016/S0031-0182(98)00029-7

Stone., P.; Richards, P.C., Kimbell, G.S., Esser, R.P., Reeves, D. (2008). Cretaceous dykes discovered in the Falkland Islands: implications for regional tectonics in the South Atlantic. Journal of the Geological Society, v. 165, p. 1-4. doi: 10.1144/0016-76492007-072

Storey, B.C. (1995). The role of mantle plumes in continental break-up: case histories from Gondwanaland. Nature, v. 377, p. 301-308

Storey, B. C., Alabaster, T., Hole, M. J., Pankhurst, R. J., \& Weve. H. ¿. (1992). Role of subductionplate boundary forces during the initial stages of Gondwa nat eak-up: evidence from the protoPacific margin of Antarctica. In Magmatism and the Cau es - iontinental Break-up, Geological Society Special Publication (pp. 149-1ㄱ) London: Geological Society. https://doi.org/10.1144/GSL.SP.1992.068.01.10

Storey, B.C., Kyle, P.R. (1997). An active mantle m'..'anism for Gondwana breakup. South African Journal of Geology, v. 100, n. 4, p. 283-290.

Storey, B.C., Leat, P.T., Ferris, J.K. (2001). T.le ) scat, on of mantle-plume centers during the initial stages of Gondwana breakup. Geologic 'Society of America Special Paper 352, p. 71-80.

Storey, B.C., Vaughan, A.P., Millar, I.L. (ـ196). Geodynamic evolution of the Antarctic Peninsula during Mesozoic times and its $\mathrm{e}_{\mathrm{i}} \mathrm{in}$ z 3 on Weddell Sea history. In: Storey, B.C., King, E.C., Livermore, R.A. (eds.) Weddr"' Si - Tectonics and Gondwana Break-up. Geological Society Special Publiation n. 108, p. s. 103

Suárez, M., \& Márquez, M. ( $\llcorner 10 \%$. A Toarcian retro-arc basin of Central Patagonia (Chubut), Argentina: Middle Juras : ic c osure, arc migration and tectonic setting. Revista Geológica de Chile, 34(1), 63-79.

Suárez, R., González, P.D., \& Ghiglione, M.C. (2019). A review on the tectonic evolution of the Paleozoic-Triassic bavins from Patagonia: Record of protracted westward migration of the preJurassic subduction zone. Journal of South American Earth Sciences, v. 95, 13 p., https://doi.org/10.1016/j.jsames.2019.102256

Talwani, M., \& Abreu, V. (2000). Inferences regarding initiation of oceanic crust formation from the U.S. east coast margin and conjugate South Atlantic margins. Atlantic Rifts and Continental Margins., 115(January 2000), 211-233. https://doi.org/10.1029/GM115p0211

Tankard, A.., Uliana, M.A., Welsink, H.J., Ramos, V.A., Tunik, M., Franca, A.B., Milani, E.J., de Brito Neves, B.B., Eyles, N., Skarmeta, J., Santa Ana et al., H., 1995. Structural and tectonic controls of basin evolution in southwestern Gondwana during the Phanerozoic. Tecton. Control. basin Evol. Southwest. Gondwana, A.J. Tankard, R. Suarez S., H.J. Weslsink, Pet. basins South Am. AAPG Mem. 62 5-52.

Thomson, K., Hegarty, K. A., Marshallsea, S. J., \& Green, P. F. (2002). Thermal and tectonic evolution 
of the Falkland Islands: Implications for hydrocarbon exploration in the adjacent offshore region. Marine and Petroleum Geology, 19(2), 95-116. https://doi.org/10.1016/S02648172(02)00005-3

Torres Carbonell, P. J., Guzmán, C., Yagupsky, D., \& Dimieri, L. V. (2016). Tectonic models for the Patagonian orogenic curve (southernmost Andes): An appraisal based on analog experiments from the Fuegian thrust - fold belt. Tectonophysics, 671, 76-94. https://doi.org/10.1016/j.tecto.2016.01.020

Torsvik, T.H., van der Voo, R., Preeden, U., Mac Niocaill, C., Steinberger, B., Doubrovine, P.V., van Hinsbergen, D.J.J., Domeier, M., Gaina, C., Tohver, E., Meert, J.G., McCausland, P.J.A., Cocks, L.R.M. (2012). Phanerozoic polar wander, paleogeography and dynamics. Earth-Sci. Rev. v. 114, pp. 325-368.

Tugend, J., Gillard, M., Manatschal, G., Nirrengarten, A.M., Harkin, C . Epin, M.E., Sauter, D., Autin, J., Kusznir, N., McDermott, K. (2018). Reappraisal of the magma-r, - h versus magma-poor rifted margin archetypes. In: McClay, K. R., Hammerstein, J. A. eds Passive Margins: Tectonics, Sedimentation and Magmatism. Geological Society, Lr... Hu.., Special Publications, v. 476, https://doi.org/10.1144/SP476.9

Turic, M. A., Nevistic, A. V., \& Rebay, G. (1996). Geolo sla v , ecursos naturales de la plataforma continental. In V. A. Ramos \& M. A. Turic (Eds.), Geo, ngía y Recursos Naturales de la Plataforma Continental Argentina (pp. 405-423).

Turner (Ed.). (1980). Geologia Regional Argentina (t, ${ }^{-c+}$, . Cordoba: Academia Nacional de Ciencias.

Uliana, M. A., Arteaga, M. E., Legarreta, L., Cer an, J. J., \& Peroni, G. O. (1995). Inversion structures and hydrocarbon occurence in Argentı.?. In J. G. Buchanan \& P. G. Buchanan (Eds.), Basin Inversion (pp. 211-233). Geologicaı - oxiety Special Publication 88.

Uliana, M. A., Biddle, K., \& Cerdán, J. ! 1 ж8\%. Mesozoic extension and the formation of Argentina sedimentary basins. Extension 1, , $^{\circ}$ cun nics and Stratigraphy of the North Atlantic Margin, AAPG Mem., 46, (3), 599-613.

Uliana, M. A., Biddle, K. T., Phelps, D. W., \& Gust, D. A. (1985). Significado del vulcanimso y extensión Mesojurasicos en el extı m $\mathrm{J}$ meridional de Sudamérica. Revista de La Asociacion Geologica Argentina, 40(3-4), 2 31-2 i3.

Urien, C. M., Zambrano, J. J., \& Martins, L. R. (1981). The basins of Southestern South America (Southern Brazil, Uruguay and Eastern Argentina) inclu ding the Malvinas Plateau and Southern South Atlantic Paleogeographic Evolution. In W. Volkheimer \& E. A. Mussachio (Eds.), Cuencas Sedimentarias del Jurásico y Cretácico de América del Sur (pp. 45-125). Buenos Aires: Comité Sudamericano del Jurásico y Cretácico.

Valicenti, V. H., \& Stephens, J. M. (1984). Ostracodes from the Upper Valanginian and Upper Hauterivian of the Sundays River Formation, Algoa Basin, South Africa. Revista Española de Micropaleontología, 16, 171-239.

Veevers, J. J., Cole, D. I., \& Cowan, E. J. (1994). Southern Africa: Karoo Basin and Cape Fold Belt. In J. J. Veevers \& C. . Powell (Eds.), Permian-Triassic Pangean Basins and Foldbelts Along the Panthalassan Margin of Gondwanaland (pp. 223-279). Boulder, Colorado: Geological Society of America. https://doi.org/10.1130/MEM184-p223

Veiga, G., Schwartz, E., Spalletti, L.A., Massaferro, J.L. 2013. Anatomy and Sequence Architecture of the early post-rif in the Neuquén basin (Argentina): A response to physiography and relative 
sea-level changes. Journal of Sedimentary Research, v. 83, p. 746-765

Vérard, C., Flores, K., \& Stampfli, G. (2012). Geodynamic reconstructions of the South AmericaAntarctica plate system. Journal of Geodynamics, 53(1), 43-60. https://doi.org/10.1016/j.jog.2011.07.007

Vergani, G. D., Tankard, A. J., Belotti, H. J., \& Welsink, H. J. (1995). Tectonic Evolution and Paleogeography of the Neuquén Basin, Argentina. Petroleum Basins of South America, 1904, 383-402. https://doi.org/10.1306/7834F6E1-1721-11D7-8645000102C1865D

Veroslavsky, G. (1999). Geologia da Bacia de Santa Lucia - Uruguai. PhD Thesis. Universidade Estadual Paulista.

Visser, D. J. L. (1998). The Geotectonic Evolution of South Africa and Offshore Areas. Pretoria.

Webster, R. E., Chebli, G. A., Fischer, J. F., Webster, R. E., Oil, H., \& 'ield, R. (2004). General Levalle basin , Argentina : A frontier Lower Cretaceous rift basin, 5( $;, ;,-2,-652$.

White, R. S., \& Mckenzie, D. (1989). Magmatism at rift zones: Th'. e e eneration of volcanic continental margins and flood basalts. Journal of Geophysical Rese $\mathrm{xr}_{\mathrm{h}}^{\mathrm{h}} \mathrm{c}$ slid Earth, 94(B6), 7685-7729.

Will, T. M., \& Frimmel, H. E. (2018). Where does a contin€ nt p reier to break up ? Some lessons from the South Atlantic margins. Gor, ana Research, 53, 9-19. https://doi.org/10.1016/j.gr.2017.04.014

Williams, G. D., Powell, C. M., \& Cooper, M. ... (1 199$)$. Geometry and kinematics of inversion tectonics. Geological Society, London, spt ziaı 'ublications; v. 44; p. 3-15

Willner, A. P., Herve, F., \& Massonne, H. J. ( $\left.\iota^{\urcorner} \cap\right)$. Mineral Chemistry and Pressure - Temperature Evolution of Two Contrasting $\mathrm{HI}_{5}{ }^{\text {h- }}$ pressure - Low-temperature Belts in the Chonos Archipielago, Southern Chile. Jol $\mathrm{rn}$.' ol Petrology, 41(3), 309-330.

Withjack, M. O., Schlische, R. W., \& Jlsı n, P. E. (2012). Development of the passive margin of Eastern North America: Mesozoic rift ing, 'rneous activity, and breakup. Regional Geology and Tectonics: Phanerozoic Rift Systems c na_- odimentary Basins. Elsevier B.V. https://doi.org/10.1016/B978-0444-56356-9.00012-2

Withjack, M., Schlisde, R., $\therefore$ Ols en, P. (1999). Diachronus rifting, drifting, and inversion on the passive margin of eastern $N$ rth America: An analog for other passive margins. AAPG Bullettin, 82(5), 817-835. https://dc ; rg/10.1306/1D9BC60B-172D-11D7-8645000102C1865D

Yrigoyen, M.R., 1975. Geologia del subsuelo y la plataforma continental, in: Geología de La Provincia de Buenos Aires, 6th Argentinean Geological Congress, Bahía Blanca. pp. 139-168.

Zaffarana, C. B., Somoza, R., López De Luchi, M. G. (2014). The Late Triassic Central Patagonian Batholith: Magma hybridization, 40Ar/39Ar ages and thermobarometry. Journal of South American Earth Sciences, 55, 94-122. https://doi.org/10.1016/j.jsames.2014.06.006

Zerfass, H., Chemale, F., \& Lavina, E. (2005). Tectonic control of the Triassic Santa Maria supersequence of the Paraná Basin, southernmost Brazil, and its correlation to the Waterberg Basin, Namibia. Gondwana Research, 8(2), 163-176. https://doi.org/10.1016/S1342937X(05) 71115-1

Zerfass, H., Chemale, F., Schultz, C. L., \& Lavina, E. (2004). Tectonics and sedimentation in Southern South America during Triassic. Sedimentary Geology, 166(3-4), 265-292. 
https://doi.org/10.1016/j.sedgeo.2003.12.008

Zerfass, H., Lavina, E. L., Schultz, C. L., Garcia, A. J. V., Faccini, U. F., \& Chemale, F. (2003). Sequence stratigraphy of continental Triassic strata of Southernmost Brazil: A contribution to Southwestern Gondwana palaeogeography and palaeoclimate. Sedimentary Geology, 161(1-2), 85-105. https://doi.org/10.1016/S0037-0738(02)00397-4

Zerfass, H., Ramos, V.A., Ghiglione, M.C., Naipauer, M., Belotti, H.J. and Carmo, I.O. 2017. Folding, thrusting and development of push-up structures during the Miocene tectonic inversion of the Austral Basin, Southern Patagonian Andes (50ㅇ). Tectonophysics 699: 102-120.

\section{Highlights:}

- Gondwana experienced poly-phased rifting, related to Mesozoic subduction dynamics.

- The Colorado and Salado basins, offshore Argentinn, $a_{i}=$ part of the Karoo system.

- Late Jurassic oblique rifting was precursor of $\mathrm{sp}$ : ?aaıng in the South Atlantic.

- The South Atlantic Rift was a highly-segrı. ən+ „d, 500 km-wide, diachronous rift system.

- North of Colorado-Cape Fracture _u 'e (?FZ), magma-rich margins formed product of interaction with the Paraná LIP. 